SUN 21928

EISRT NRY

THE MORE MMPORTANT

SHADE TREE IMSECTS

OF EASTERN CAMADA.

AHO THEIR CONTROL

By J.m.Swaine and CB.Hutchings

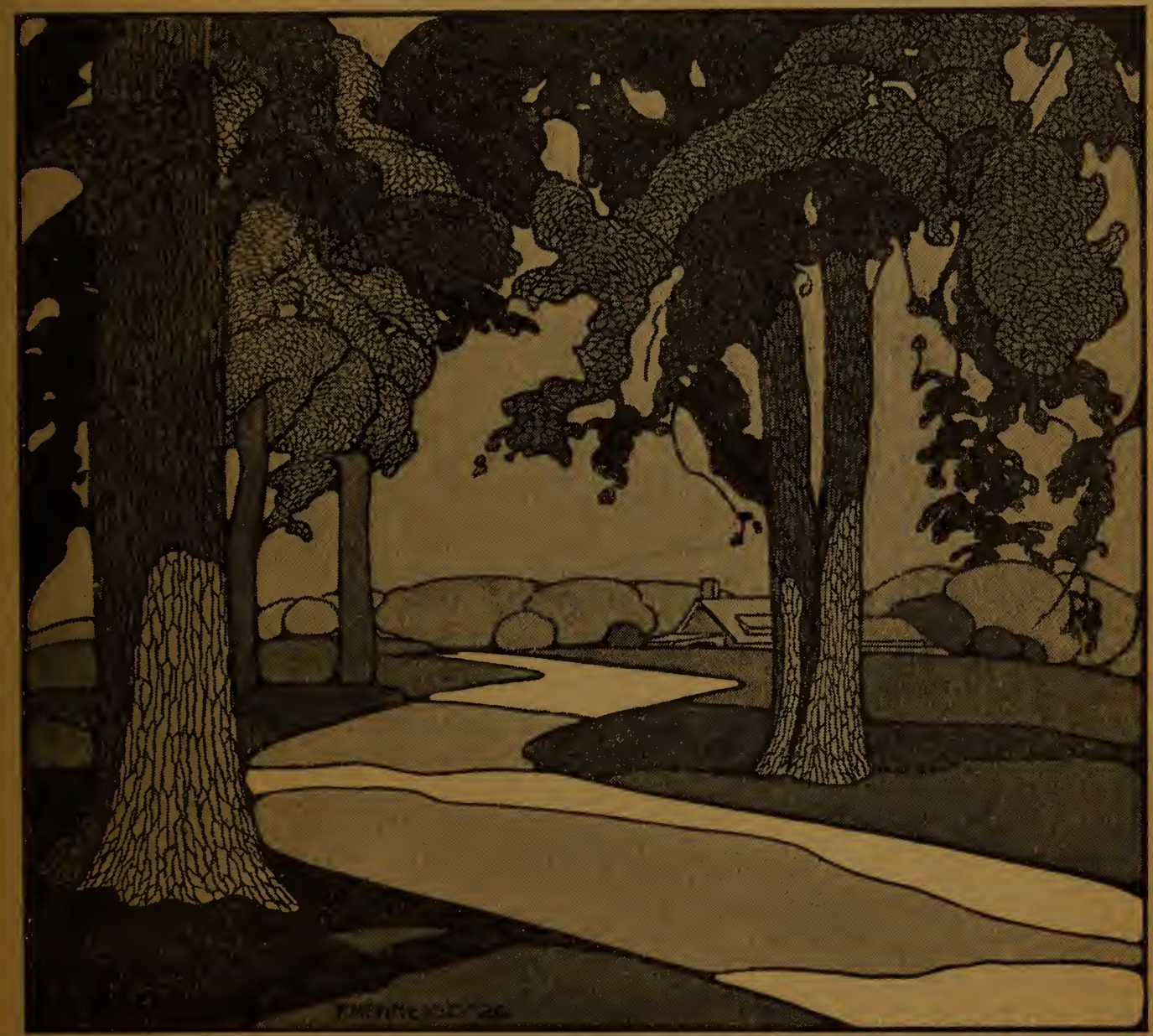

DOMINION OF CANADA

DEPARTMENT OF AGRICULTURE

BULLETIN No. 63-NEW SERIES 


\section{ENTOMOLOGICAL BRANCH}

Dominion Entomologist............................ Gibson Associate Dominion Entomologist................. M. Swaine Division of Forest Insects.................... M. Swaine (in charge) Chief, Division of Foreign Pests Suppression........... S. McLaine Chief, Division of Systematic Entomology............ H. McDunnough Chief, Division of Field Crop and Garden Insects...... H. G. Crawford

\section{LABORATORIES}

Annapolis Royal, N.S.....Headquarters for Insecticide Investigations: Arthur Kelsall, Entomologist in charge.

Fredericton, N.B.........Field Crop Insect Investigations: R. P. Gorham, Assistant Entomologist in charge.

Insecticide Investigations: G. P. Walker, Assistant Entomologist in charge.

Forest Insect Investigations: L. J. Simpson, Junior Entomologist in charge.

Hemmingford, Que........ Fruit Insect Investigations: C. E. Petch, Entomologist in charge.

Aylmer, Que............Forest and Shade Tree Insect Investigations: C. B. Hutchings, Assistant Entomologist in charge.

Vineland, Ont........... Fruit Insect Investigations: W. A. Ross, Entomologist in charge.

Strathroy, Ont........... Field Crop Insect Investigations: H. F. Hudson, Assistant Entomologist in charge.

Chatham, Ont...........European Corn Borer Parasite Investigations: A. B. Baird, Assistant Entomologist in charge.

Treesbank, Man..........Field Crop Insect Investigations: Norman Criddle, Entomologist in charge.

Indian Head, Sask.........Forest and Shade Tree Insect Investigations: J. J. de Gryse, Assistant Entomologist in charge.

Live Stock Insect Investigations: Eric Hearle, Assistant Entomologist in charge.

Saskatoon, Sask..........Field Crop Insect Investigations: K. M. King, Entomologist in charge.

Lethbridge, Alta..........Field Crop Insect Investigations: H. L. Seamans, Entomologist in charge.

Agassiz, B.C........... Field Crop and Fruit Insect Investigations: R. Glendenning, Junior Entomologist in charge.

Vernon, B.C............Forest Insect Investigations: Ralph Hopping, Entomologist in charge.

Fruit and Field Crop Insect Investigations: E. R. Buckell, Entomologist in charge.

Victoria, B.C........... Fruit Insect Investigations: W. Downes, Assistant Entomologist in charge.

(ENTOMOLOGICAL BULLETIN No. 28) 
Digitized by the Internet Archive in 2013

http://archive.org/details/moreimportantsha63swai 


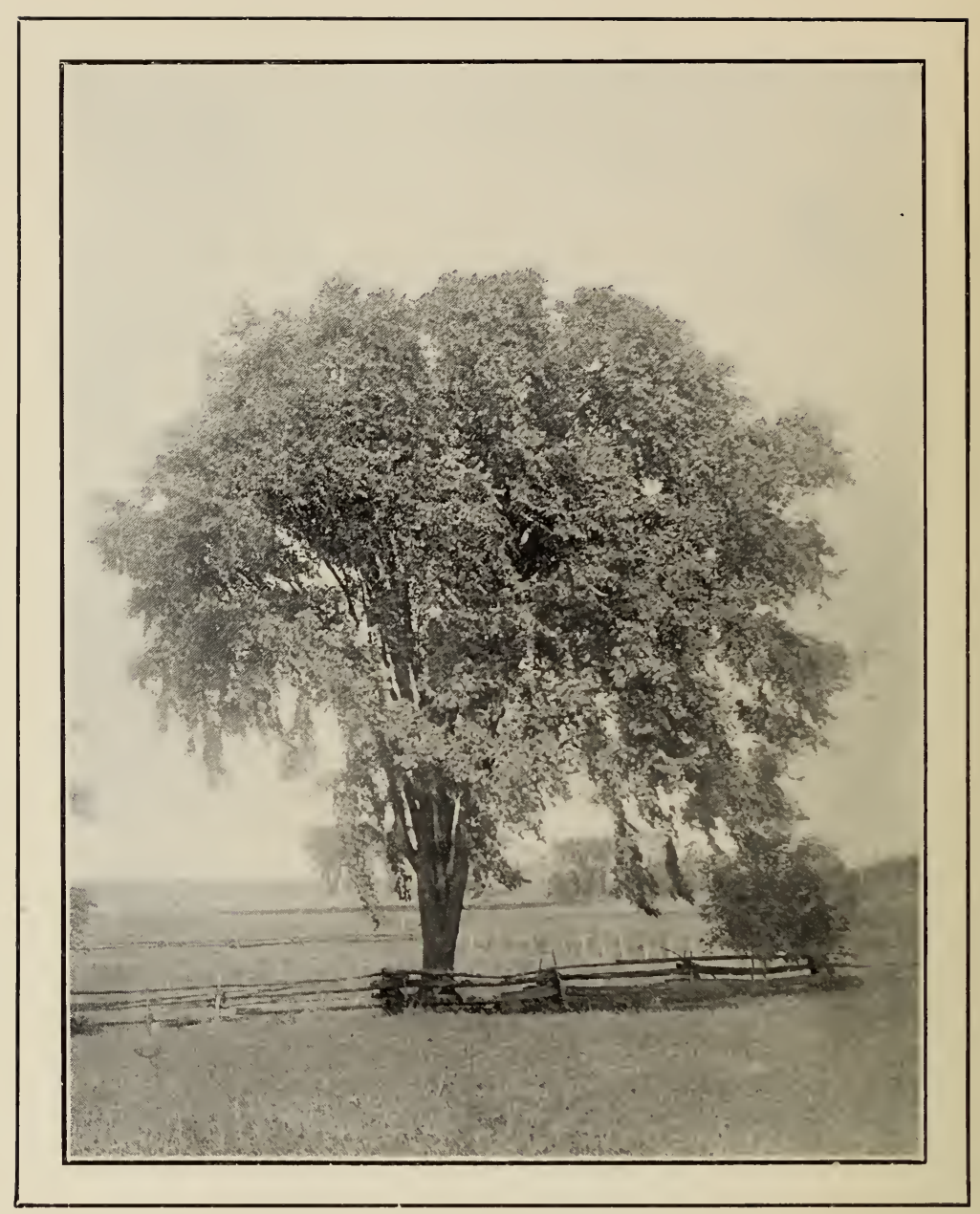

White Elм, L'lmus americana, Linn.

Courtesy of Forestry Branch, Department of Interior, Ottawa. 


\title{
The More Important Shade Tree Insects of Eastern Canada and Their Control
}

\author{
By J. M. Swaine and C. B. Hutchings
}

\section{INTRODUCTION}

The shade trees of our cities, towns and villages are attacked each summer by many insect enemies, and more or less seriously injured thereby. Very frequently the foliage is disfigured for a great part of the season through unsightly webs and partly eaten leaves, and very often dying branches and ruined trees are the final result.

The losses incurred in this way are chiefly in the beauty and comfort provided by the trees, and while this may be difficult to express in dollars, the injury is none the less a very real one. A good shade tree requires many years to grow and demands a certain care and attention; apart from its aesthetic value it has also a definite money value. The courts have established the worth of well grown shade trees at as much as several hundred dollars each; and since thousands of shade trees are ruined and killed each year in Canada by injurious insects, the actual monetary loss incurred in this way amounts to a very large sum.

The shade tree insects of Eastern Canada include borers in the bark and wood of the trunk and branches, and leaf-feeding insects of various kinds, such as caterpillars, leat-beetles, sawfly larvæ, plant lice, scale insects, gall-making insects and various others.

It is possible to control most insect attacks on trees which are valuable enough to warrant individual treatment; but very many of these injuries could be prevented by proper handling of the trees, and considerable expense and trouble could thus be avoided.

\section{SELECTION AND PLANTING}

Mistakes are often made in selecting the trees for planting. Good stock should be chosen of varieties which are suited to the climate and soil conditions of the location. Trees which are likely to succumb to local insect pests should be avoided. It is almost useless, for instance, to plant the white birches in districts where the bronze birch borer is abundant. For city planting, elms, maples, oaks, basswood and ash are most suitable.

The trees should be planted carefully and properly* and an abundance of water should be furnished the roots in dry seasons. The weaker, unthrifty trees should receive special attention, or should be replaced. Vigorous trees in full sap are much better able to withstand the attack of destructive borers, and are, of course, more likely to recover from attacks by defoliating or sucking insects, or from injuries of any sort.

\section{TREATMENT OF WOUNDS}

Protection from injuries and the proper treatment of damaged trees are of the utmost importance. Whenever the bark is broken and left untreated, insects and fungi are almost certain to gain entrance. Many of the most serious injuries from decay originate from wounds through which the parasitic fungi enter. Broken branches should be trimmed off smooth and even with the trunk; and the bare surface, unless very small, should be coated with creosote and tar (1 part creosote mixed with 2 parts tar) or with a good paint that does not con-

${ }^{*}$ The Planting and Care of Shade Trees, Dominion Experimental Farms, Dapartment of Agriculture, Ottawa, Bull.
No. 19 . $16859-2$ 
tain turpentine (pure white lead and linseed oil), thoroughly covering the entire wood surface excepting the junction between the living outer wood and the inner bark, which should be left uncoated. Very small wounds may be covered safely with grafting wax. Wounds on the trunks or limbs should be smoothed off and similarly coated. Any needed pruning should be done during the dormant period of the tree.

Injury from wind and sleet storms can be lessened by chaining or bolting weaker upright branches together or to the trunk. Reasonable care in the prevention of injuries and in the proper treatment of affected trees will prevent much trouble from boring insects and fungous rots.

Trees which have been badly injured by decay can be saved in many cases by proper surgical treatment. The decayed portions should be entirely removed and the healthy surface thus laid bare thoroughly disinfected with creosote, excepting the junction between the bark and wood, which may with advantage be coated with a ring of shellac immediately after the cut is made. The parts should then be bolted together if such support is required, and the cavity filled with cement. It is best to have any important work of this kind done by an expert in tree surgery, if such services are available.

Trunks of city trees frequently require protection from injury by horses and by vehicles. Guards of stout metal fencing are effective. Pavements of concrete or asphalt should not be extended close to the trees. A large circle of bare ground should be left about the trunk for the admission of air and water.

\section{CLEAN CULTURE}

All dying and dead branches and trees should be removed and burned. Many insects and rot-causing fungi breed in such material and emerge therefrom to attack weakened or even healthy trees. It is of the utmost importance to cut out or collect and burn all such material promptly so as to destroy the pests which it contains. Each fall and winter remove all dying and dead trees and branches and burn them before spring. Make it a rule to cut out and burn unhealthy wood as soon as detected. Time and labour spent on this work will be well repaid.

\section{INSECT STAGES}

Insects are jointed, air-breathing animals. In the adult stage there is a distinct head, a thorax and an abdomen, one pair of antemnae attached to the head, three pairs of jointed legs and usually one or two pairs of wings attached to the thorax, and mouth parts which are variably adapted for biting, sucking or lapping.

Most insects reproduce by means of eggs, although a few, such as aphids and sawflies, deposit living young.

In some species (grasshoppers and bugs) the young stages, called nymphs, resemble the adults more or less closely in appearance. They change the skin several times, increasing in size and similarity to the adult at each moult, and finally reach the adult stage, usually winged, after which there is no further change in size or shape.

The young stages of other species (flies, bees, moths and beetles) may be entirely different in appearance from the adult; they may lack the wings, and in many species the jointed less, or, in some, even the mouth parts. In these insects the young is known as a larva. The larva of beetles are called grubs; those of flies are called maggots; those of butterflies and moths are called caterpillars and those of sawflies slugs or false-caterpillars.

The larva, after reaching full growth, changes to the resting stage or pupa, which finally transforms to the adult insect. The pupa may be naked, as the chrysalis of a butterfly, or, surrounded by a cocoon construeted of silk, earth or chips, as in the case of some moths and bectles, or, by the hardened last larval skin (puparium) as in the two-winged flies. 


\section{NATURAL CONTROL}

Our shade tree insects are in most cases native species which are normally found in the forests. Some of them are of little importance in large areas of woodland, but become exceedingly troublesome under the more or less isolated conditions of cultivated trees, where there is little opportunity for distribution, and the attack of the pests is relatively concentrated. The spruce gall aphids are abundant very often in spruce forests but cause no evident injury, while on spruce as shade and ornamental trees they are very destructive enemies.

On the other hand, some of our most injurious shade tree enemies have been introduced into this country from the United States, or, originally from Europe. The larch sawfly, the brown-tail moth, the gypsy moth, the elm and alder leaf miners, the mottled willow borer, the satin moth and the elm bark-louse are examples of these troublesome immigrants. In their native country these insects are held more or less effectively in check by special parasitic and predaceous enemies and in some cases it has been found necessary to import into this country certain of these useful parasites and predators to aid in coping with the introduced pests.

Changed conditions about centres of population have driven away the insectivorous birds and thereby favoured the development of insect outbreaks. Every effort should be made through protection and the provision of nesting boxes and watering places, to encourage song birds to remain about thickly populated districts.

Also, changed conditions in the forest, produced by our civilization, have apparently favoured in different ways the development of forest insect epidemics, and these have, in some measure, affected our shade trees.

Some of our shade tree insects occur periodically in outbreaks lasting for one, two or three years in succession, and then disappear almost completely for several years. The reason is they are overcome by their natural enemies and other natural control factors, which include parasitic and predaceous insects, bacteria and fungi, birds, adverse weather conditions, and lack of food on the defoliated trees. For several years following the cessation of the outbreak, the injurious insects may be almost rare; then they gradually begin again to increase, until, finally, when the most favourable conditions for their breeding occur, they multiply with tremendous rapidity and an epidemic condition consequently is again produced. The important function of beneficial insects is to hinder the increase of injurious species and thus to help in preventing the development of great outbreaks; but, unfortunately, the parasites and predators are rarely able to check an extensive outbreak of injurious insects before great injury has been caused to the trees, and artificial measures of control are, therefore, often necessary.

\section{ARTIFICIAL CONTROL}

Injurious insects feed either by biting off parts of the plant with their jaws or by sucking the juices through a slender beak inserted into the tissue. The biting insects, such as beetles, caterpillars, and sawfly larvæ, which feed upon the foliage, are usually killed most easily by spraying the infested foliage with a stomach poison, such as arsenate of lead. The sucking insects, as for example plant lice and scale insects, are not affected by stomach poisons and must be sprayed with insecticides which kill by contact, such as nicotine sulphate or oil emulsions.

\section{SPRAYING}

The methods and materials employed in spraying shade trees are much the same as those required for the treatment of trees in the orchard, except that frequently greater heights have to be reached, and consequently a more powerful apparatus is required. For spraying the lower foliage the ordinary nozzles and equipment may be used; but to reach the top of the higher trees it is necessary to employ a solid stream spray and a powerful pump of large capacity. 
A number of types of spraying machines are now on the market. In purchasing these one should consider the nature of the work to be done, the amount of pressure attainable, and the different accessories required for ordinary or special work.

Bucket pumps (fig. 1) if well constructed, especially if they have a fairly large air chamber, are capable of developing considerable pressure. They are effective in treating a limited number of very small trees or shrubs.

Barrel pumps (fig. 2) have a wider range of usefulness than bucket pumps. A good pump of this type equipped with a 25-foot line of hose, an eight-foot extension rod and a drive spray nozzle may work effectively for trees up to a height of about 20 feet, or much higher if a ladder and a longer hose be used. A straight nozzle about 4 inches in length with a very small bore gives the best results.

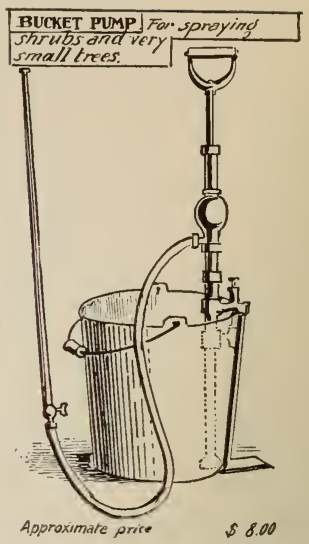

Frg. 1.-Bucket pump. (After de Gryse.)

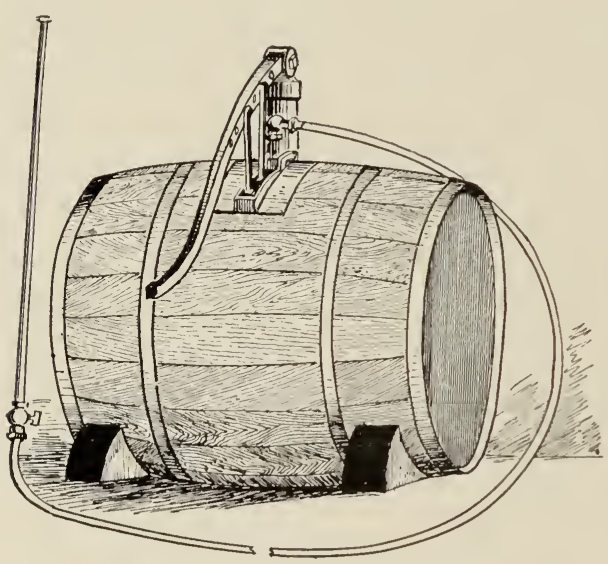

FIG. 2.-Barrel pump. (Ifter de (iry'se.)

of the power spray-pumps sold for orchard work will maintain a solid stream for 50 feet up from the nozzle; other pumps excellent for general work in the orchard, have a small pumping capacity and are unable to maintain a solid stream much above 30 feet. By using a good straight drive nozzle, long hose, and elevating the nozzle on a platform or ladder, the average orchard power sprayer can be made fairly effective for reaching shade trees of moderate height.

For towns and cities, where large numbers of tall trees are to be sprayed, special power sprayers designed for shade tree purposes should be obtained. Several types of these powerful pumps are now available, capable of maintaining a solid stream from 80 to 100 feet up from the nozzle. The essential requirements of an efficient shade tree sprayer are: a high pump capacity, preferably more than are practical for spraying shelter belts and also street trees in small towns. They are more powerful than the ordinary barrel pump and may be used with tanks of 120 to 200 gallons capacity. The types now on the market can be geared to a small gasoline engine and are best used in that way, since they are somewhat difficult to operate by hand. In spraying tall trees the nozzle must be carried well into the top, necessitating the use of a long hose, ladders and climbing irons.

For large operations a power sprayer is indispensable (fig. 4). A few

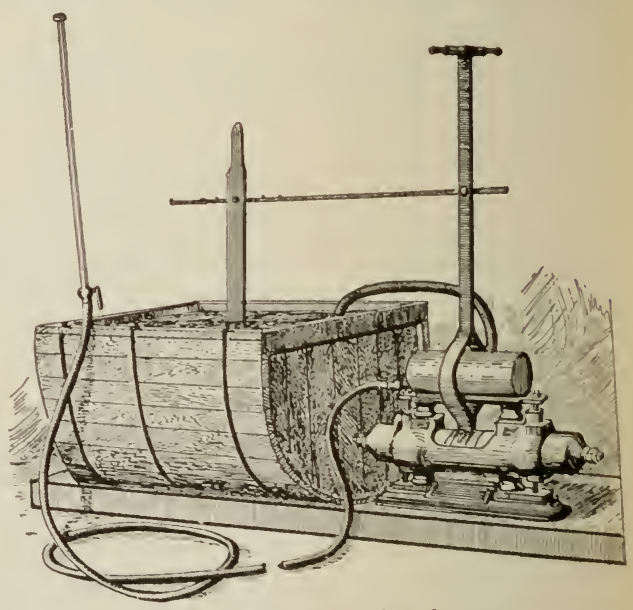

FIG. 3.-Double action hand pump. (After de Gryse.) 
20 gallons per minute, and an engine capable of maintaining continuousiy a nozzle pressure of 225 pounds. Very strong hose and special couplings are necessary for this work on account of the high pressure employed. Straight bore nozzles, such as the "Worthley", are required to deliver the solid stream of spray which breaks high in the air into a fine mist. A special attachment is employed to break the spray closer to the ground when spraying lower foliage. The crew for spraying in city streets should include an experienced foreman, an engine man, a driver, a nozzle man, and several hose carriers, as the length of hose may require.

In spraying for shade tree insects thoroughness is an absolute necessity. A mist spray at high pressure should be employed for as high as the extension or spray gun will reach, and for the higher portions the solid stream is necessary. The latter uses the spray mixture very rapidly and should be employed with discretion. It is, of course, essential to understand the habits of the insects to be controlled and to apply the sprays at the proper time.

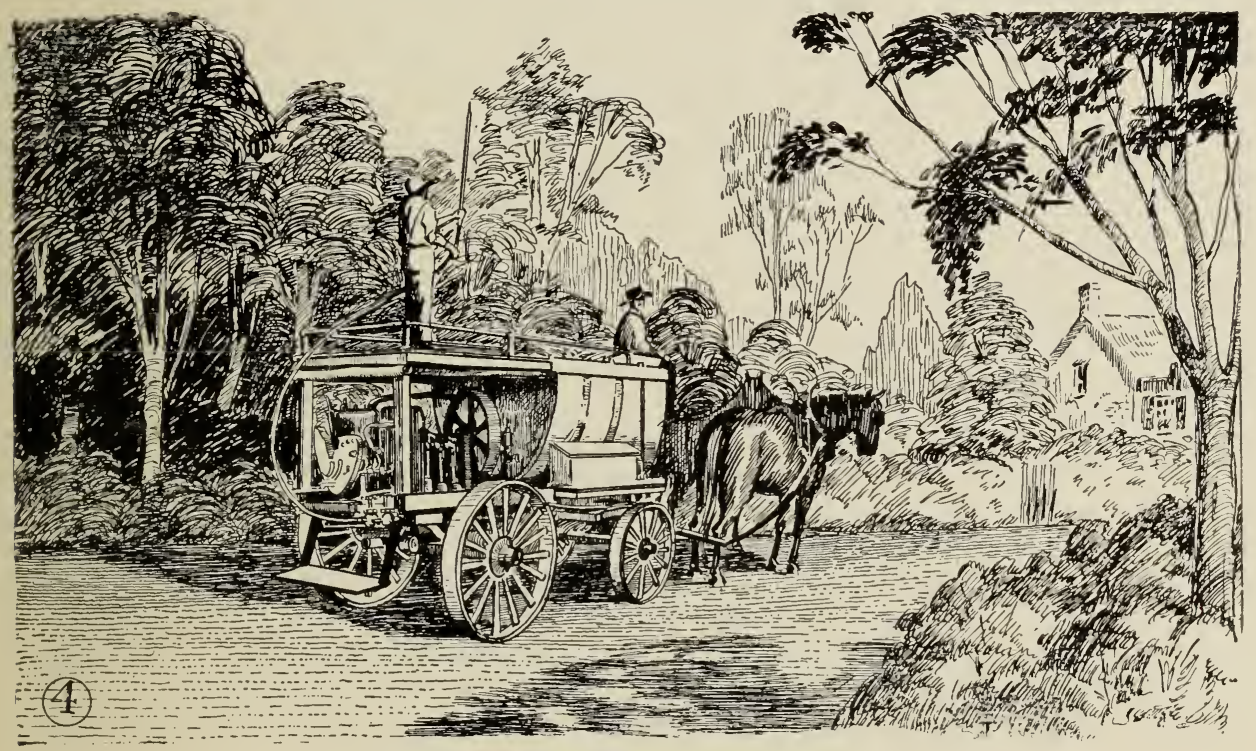

FIG. 4.-Power sprayer. (After de Gryse.)

\section{INSECTICIDES}

\section{STOMACH POISONS}

Arsenate of Lead is the safest and most satisfactory insecticide for the control of biting insects on shade trees. It is sold in the form of a paste and also as a powder, the powder being about twice as strong as the paste and more commonly employed. The paste should be guarded from drying and from freezing. The addition of a small amount of soap to the spray will cause it to adhere better and to spread more evenly. The formula for ordinary use is:-

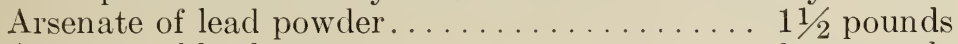

or Arsenate of lead paste...

Soap (laundry or fish-oil).

3 pounds

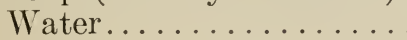

1 pound

40 gallons

Mix the required amount of poison with a little water before adding to the water in the spray tank, add the soap dissolved in a small amount of hot water, and stir the whole thoroughly. For resistant forms the poison may be used as strong as 8 pounds of paste or 4 pounds of powder in 40 gallons of water. For small quantities use 2 teaspoonfuls of powder in one gallon of water. 


\section{CONTACT INSECTICIDES}

Nicotine Sulphate is one of the most satisfactory contact sprays for use against many sucking insects, particularly plant lice. Its effectiveness is increased by the addition of a small amount of soap. Commercial preparations may be obtained containing 40 per cent of nicotine sulphate. This is used at different strengths; the formula for common use is:-

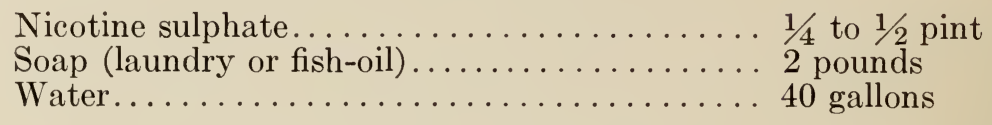

Kerosene Emulsion was formerly the standard remedy for use against plant lice and other sucking insects. It is troublesome to prepare, but the ingredients are always readily obtainable, and it is, therefore, useful in emergencies.

A stock solution is prepared and may be kept for some time. The spray material is made by mixing a portion of the stock solution in the required amount of water.

\section{Stock solution:-}

Kerosene (coal oil)................. 2 gallons

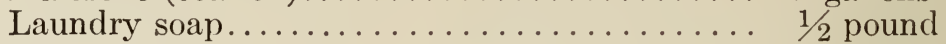

Water....................... 1 gallon

Heat the water, cut the soap into fine shavings and add to the water, stirring till all the soap is dissolved; then pour this into the kerosene and churn the whole violently with a syringe or force pump until a thick creamy emulsion is produced. This makes the stock solution, which must be diluted with water when being used as a spray. As the stock solution cools it thickens into a jellylike mass.

Soap Solutions may be employed as contact insecticides; but they are used chiefly in emergencies and when only a small amount of spray is needed. Specially prepared insecticidal soaps may be purchased or the less effective, but easily obtainable laundry soap may be used instead. Soap solution is of the greatest use in controlling plant lice and is prepared by dissolving one pound of soap in 5 to 8 gallons of water.

Miscible or Soluble Oils may be obtained which mix readily with water. They are particularly effective on shade trees in the control of scale insects, being applied usually during the dormant period of the tree. The spray solution for dormant trees is made by mixing 1 part of the oil in 15 parts of water for most scale insects, and 1 to 20 for spruce gall aphis. The miscible oils should be applied to conifers only with great caution, and hard maples are also reported to be particularly susceptible to injury.

\section{POISONED CONTACT SPRAY}

A poisoned contact spray is often effective in controlling borers in the bark and wood of living trees. To prepare the spray solution, add one ounce of dissolved sodium arsenite to each gallon of contact spray, such as kerosene emulsion or miscible oil. This is sprayed on the infested trunks and branches so as to soak into the tunnels as far as possible. The foliage should not be sprayed with the mixture. 


\section{DUSTING}

The application of poisons in the form of dusts is effective on the lower foliage of shade trees, employing the methods used in dusting orchard trees. A hand dusting machine may be used for treating shrubs and very small trees.

\section{HAND PICKING}

This method of treatment necessarily has its limitations. The tents of the American tent caterpillar and the fall webworm can be removed by means of tree-trimmers or torches; egg-masses of the tent caterpillar can be removed by hand, at times, with profit; the eggs of the white-marked tussock moth and of the gypsy moth can be painted with creosote; galls of the spruce gall aphis, on small trees, can be removed by hand while still green; and the larger caterpillars, which rarely occur in great numbers, can sometimes be removed from low foliage by hand more cheaply and effectively than in any other way.

\section{THE DESTRUCTION OF LARGE WOOD BORERS}

When living trees become infested with large boring grubs or caterpillars it is necessary to kill the borers in their tunnels with the least possible injury to the trees. When the borers are near the surface it is often possible to cut thein out with a knife or chisel without much injury to the wood. A wire thrust into the borings can sometimes be used effectively. It is usually possible to kill the grubs by injecting carbon bisulphide or benzine into the openings. The fluid should be injected with a syringe or oil-can and the opening immediately plugged with soap or putty. After several hours the holes may be opened; the grubs removed if easily reached; decaying wood cut away; the holes thoroughly disinfected with creosote or with a solution of bichloride of mercury, and finally filled with cement. The carbon bisulphide or the benzine, should be injected into the flatter holes from which sap and borings have been oozing and which evidently lead to the tunnels of living larvae. It is useless to inject insecticides into the exit holes from which the adults have escaped, although such holes should be disinfected and filled with putty or cement.

Many of these borers feed repeatedly near the surface, enlarging their tunnels, and it is possible to kill some of them by spraying the infested trunks, or branches, with poisoned oil emulsions.

\section{BANDING THE TRUNKS}

Banding the trunks of deciduous trees to prevent infestation from wandering hordes of caterpillars or from wingless females of the cankerworms is often a necessary precaution. The most effective method is to make a complete girdle about the trunk with a sticky substance over which the insects cannot crawl. The adhesive should be applied in a band about four inches wide to stout paper tacked or tied about the trunk about five feet from the ground. If the bark is uneven cotton should be placed beneath the paper to prevent the insects passing beneath; or a portion of the trunk may be scraped smooth and the adhesive applied directly on the bark. One of the best adhesives for bandingis made by boiling resin and castor oil in equal parts and thoroughly mixing. The well known preparation "Tree Tanglefoot" is widely used for this purpose, and can be obtained from dealers in insecticides. The common sticky fly paper, tied about the trunk, is effective for a time. A band of cotton batting tied about the trunk with a strong string so that the upper half hangs down over the tie is also useful. 


\title{
Leaf-eating Insects
}

\author{
The Forest Tent Caterpillar
}

\section{(Malacosoma disstria Hubn.)}

These caterpillars occur periodically in great infestations, feeding upon the foliage of poplar, willow, birch, ash and other hardwood trees. Vast areas of

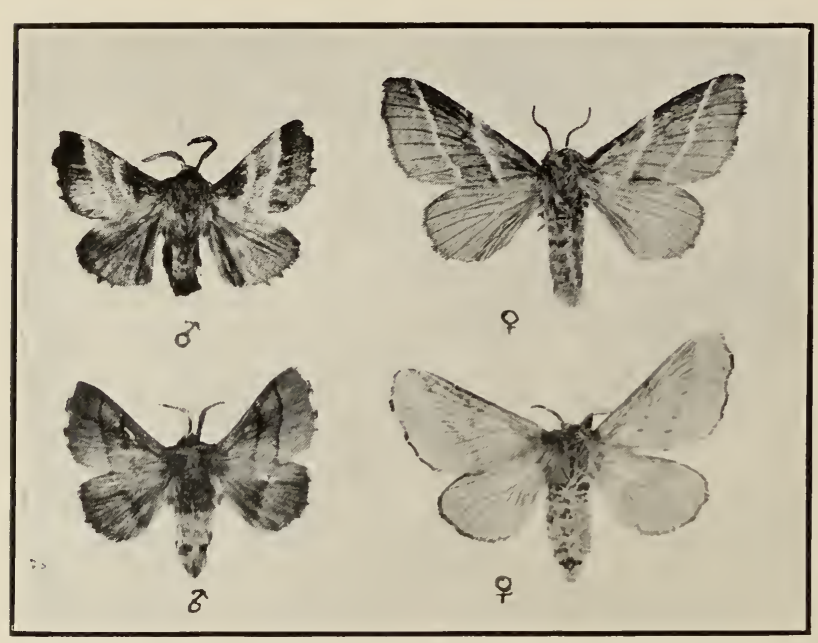

FIG. 5.-American tent caterpillar moths, above; forest tent caterpillar moths, below. $\sigma^{7}$, male; $\sigma^{7}$, female. (After Swaine.) poplar forests are at times almost completely defoliated for several years in succession, the trees being disfigured for a large part of the season and finally weakened to a serious degree. Since the feeding occurs early in the season the trees develop a second growth of leaves during August; they are able, therefore, to recuperate in some measure before winter. After the foliage has been stripped from large areas the starving caterpillar's swarm. over the neighbourhood in search of food to the great annoyance of the inhabitants.

The caterpillars hatch from the eggs on the first warm days in spring about the time the buds are opening, and immediately commence feeding on the young leaves. In colour they are bluish-grey with a row of elongate whitish spots along the back. They become full grown in June, spin ycllowish silken cocoons between the leaves or in any protected place, and pupate therein. The small, chocolate-brown moths emerge from the cocoons in late June and early July and deposit their eggs in ring-like bands, containing 150 or more eggs in eacn, around the twigs of trees. The eggs remain on the twigs during winter and hatch early in the following spring.

Control.-Pruning off and burning the egg-masses during fall and winter is effective if the work is thoroughly done. This plan, however, is frequently not feasible on large trees on account of the abundance of egg-masses on the top-most branches. $A$
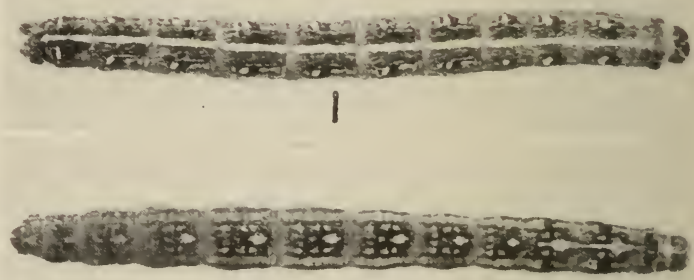

2

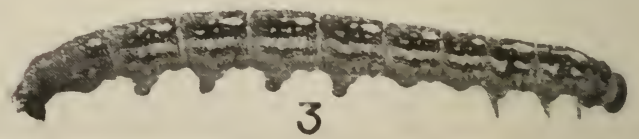

FIG. 6.-1. American tent caterpillar. 2 and 3 . forest tent caterpillar. (After Swaine.) 
dozen neglected egg-masses will furnish a large number of caterpillars.

Spraying the infested trees with arsenate of lead at the rate of $11 / 2$ pounds of powder in 40 gallons of water, as soon as the caterpillars appear in the spring, is the most dependable method of control. If the caterpillars are half grown before the spray is applied, $2 \frac{1}{2}$ pounds in 40 gallons of water should be used. Clustering or migrating caterpillars may be destroyed by crushing with a stiff brush attached to a long pole, or by spraying with strong kerosene emulsion, or with kerosene when the masses of caterpillars are off the trees.

Banding the trees after spraying affords additional protection from wandering caterpillars and is necessary when the latter are

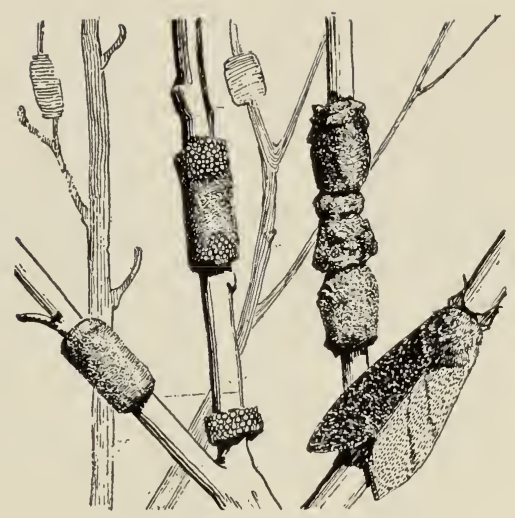

FIG. 7.--Egg masses of forest tent caterpillars. (After de Gryse.) abundant.

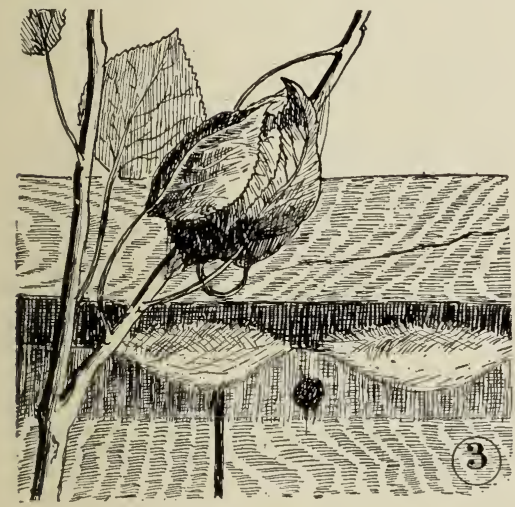

FIG. 8.-Cocoons of forest tent caterpillar. (After de Gryse.)

\section{The Maple Leaf-Cutter}

(Paraclemensia acerifoliella Fitch)

Extensive outbreaks of this species have occurred during the past few years in the sugar bushes of Quebec and Ontario.

The caterpillar is protected by an oval case formed of four layers cut from the leaf. It skeletonizes the leaf in a subcircular ring about the case and then moves to another location, the injured portion of the leaf frequently falling out and leaving a hole nearly half an inch in diameter. The larvae feed from July to September, and when full grown descend to the ground, pupate within their
The American Tent Caterpillar (Malacosoma americana Fabr.)

This species is closely allied to the foregoing. The caterpillar has a white line down the back, replacing the row of spots of the forest tent caterpillar. It is a common orchard pest and is frequently found on wild cherry and hawthorn. The caterpillars are gregarious and spin a regular and conspicuous silken "tent" in the junction of branches, within which they retire at night and in wet or cold weather. This species feeds only in the early part of the season and is frequently confused with the later appearing fall webworm.

Control.-As above, combined with prompt destruction of tents containing the caterpillars.

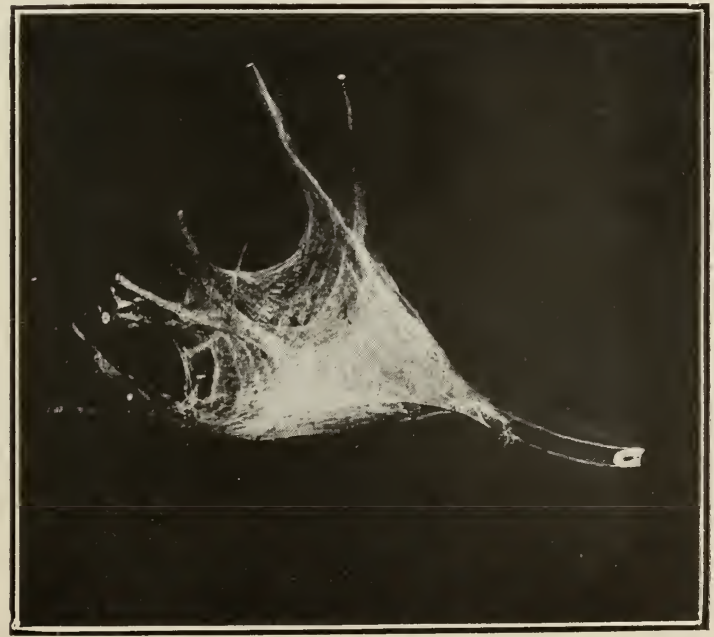

FIG. 9.-Tent of American tent caterpillar. (After Swaine.) 
cases, and hibernate below the surface litter. Late in May of the following year, the minute steel-blue moths emerge and deposit their eggs in the leaves, and the young larvae excavate mines between the leaf surfaces, emerging in

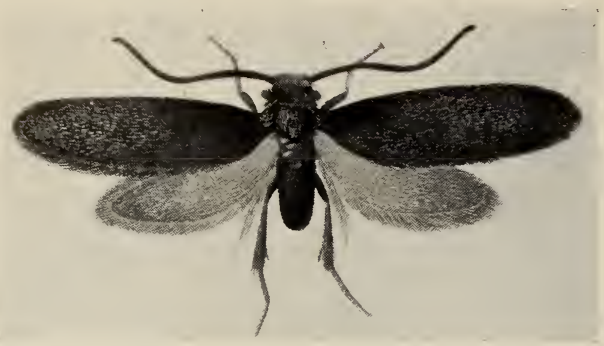

FIG. 10.-Maple leaf-cutter moth, greatly enlarged. (After Hutchings.) about two weeks, to construct the case within which the remainder of the larval and the pupal life is passed.

In severe outbreaks the maples are defoliated to a considerable degree for several years in succession, with a consequent disfiguration and loss of vigour.

Control.-Burning the leaf litter after all the leaves have fallen should destroy the majority of the hibernating insects. It should be possible to burn the leaves thoroughly without injury to the trees if the litter is raked away from the trunks and the fire carefully guarded. Where possible, this work should be done in the afternoon as the wind is less likely to rise then than during morning hours.

Serious defoliation can be prevented by spraying thoroughly as soon as the injury becomes apparent, with lead arsenate powder, $1 \frac{1}{2}$ pounds in 40 gallons of water.

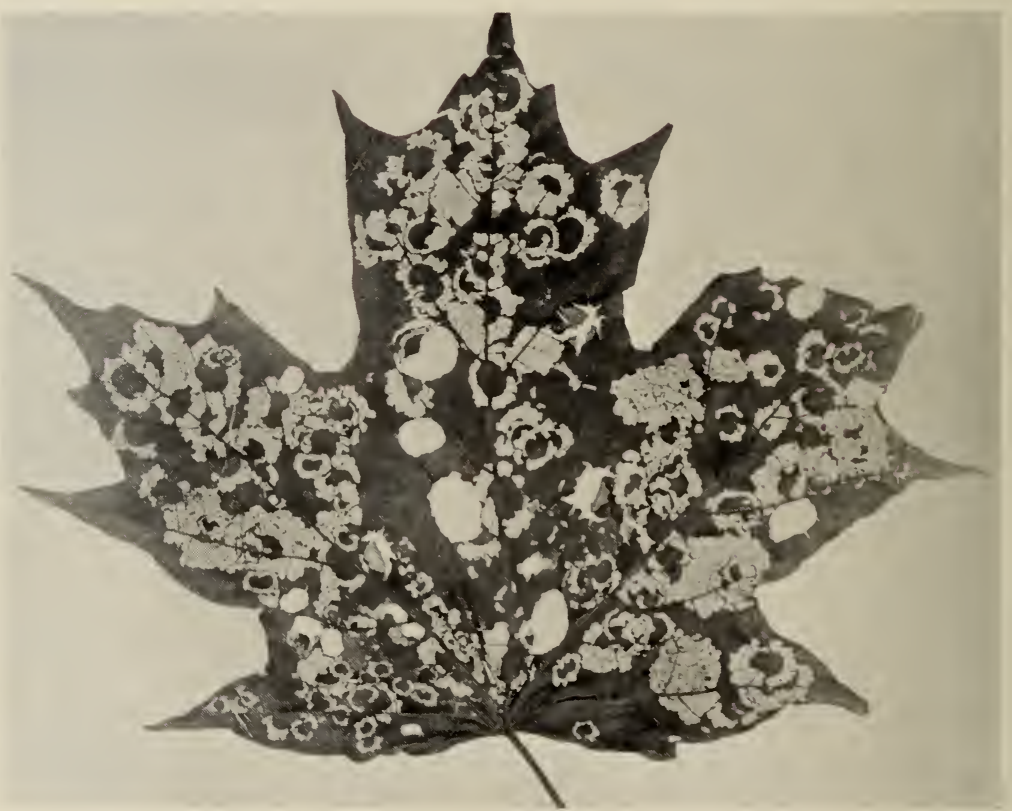

FIG. 11.-Work of the maple leaf-cutter on sugar maple. (After Hutehings.) 


\section{The Spring Canker Worm (Palaeacrita vernata Peck)}

\section{The Fall Canker Worm (Alsophila pometaria Harris)}

These small caterpillars occur periodically in great numbers and often completely defoliate maple trees for several years in succession, disfiguring and frequently killing the trees. Elm, ash, oak, willow, birch and fruit trees are also severely injured.

The caterpillars are slender, light or dark brown and green in colour, marked with narrow stripes. The species known as the fall cankerworm has three pairs of prolegs at the rear end of the body and the one known as the spring cankerworm, two pairs. Owing to their peculiar method of locomotion, due to the legs being at the front and hind ends of the body, they are known as measuring worms, or loopers. They appear early in spring when the buds are opening and feed voraciously on the tender foliage. During June they become full grown and drop to the ground to pupate beneath the surface. In the case of the fall cankerworm, the majority of the moths emerge from the pupae late in the autumn. The females are wingless, greyish in colour, about $1 / 2$ inch in length.

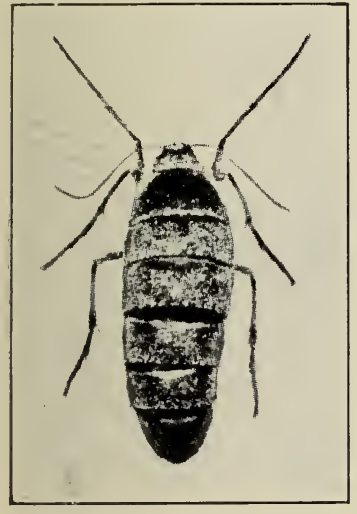

Fig. 13.-Fall cankerworm, female moth, enlarged $2 \frac{1}{2}$ times. (After Slingerland and Crosby.) They crawl up the trunks of the trees and deposit their eggs in clusters on the branches and trunk. The moths of the spring cankerworm appear early in the following spring and have the same general habits. The males of both

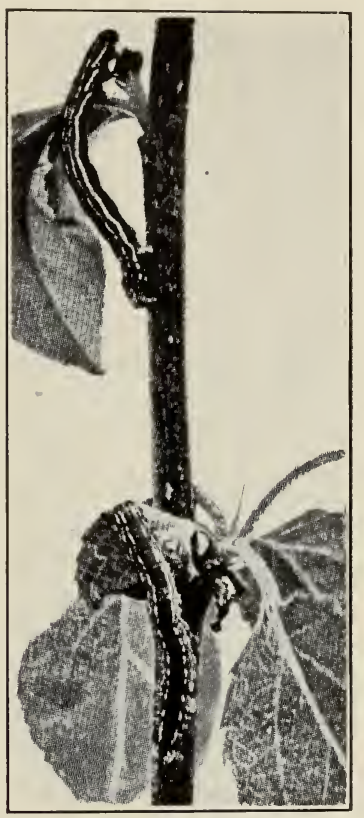

Fig. 12.-Fall cankerworms. (After Slingerland and Crosby.) species are very delicate moths, greyish in colour, the fore-wings darker than the hind-wings, and have a wing expanse of slightly more than an inch.

Control.-Tanglefoot bands should be applied about the trunks late in September to prevent the ascent of the wingless females to deposit their eggs. The bands should be kept fresh by combing each week until winter, and freshened or renewed in early spring before the buds open. When the moths are abundant, their bodies bridge the neglected bands so that late appearing females may cross in safety. Owing to the habit of the young larvae of drifting considerable distances on threads of silk, protected trees may becoms infested from neglected groves in the neighbourhood. In that case, it may be necessary to supplement the banding by arsenical sprays.

If the trees have not been protected by banding or the caterpillars are

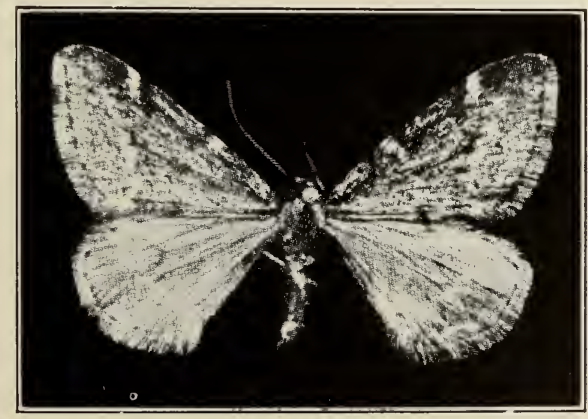

FIg. 14.-Fall cankerworm, male moth, twice enlarged. (After Slingerland and Crosby.) 
already feeding when discovered, the foliage should be sprayed very thoroughly as soon as the leaves are about one inch long, with lead arsenate at the rate of 2 pounds of the powder in 40 gallons of water. In some cases it may be necessary to repeat the spray. If the spraying is delayed until the caterpillars are half-grown, twice as much poison should be used. Special care should be taken to cover the upper foliage very thoroughly with the arsenical.

\section{The Gypsy Мотн}

\section{(Porthetria dispar Linn.)}

This species was introduced into the United States from Europe about 1870 and since that time has spread throughout a large part of the New England States and as far north as southern Quebec.

The gypsy moth caterpillars feed upon a wide variety of plants. The apple is the favourite food plant, but a preference for oak, birch, willow, elm, and poplar is shown. More than 500 different kinds of plants, however, are known to be eaten by them, including practically every native tree and shrub in Eastern America.

Enormous sums of money have been spent in the United States in the attempt to control this most destructive pest and prevent its distribution; nevertheless, the infestation has been spreading slowly westward and northward until finally, in the summer of 1923, a colony of the gypsy moth was discovered in Vermont within half a mile of the Canadian line. During the summer of 1924 a careful survey was conducted in southern Quebec and one small colony was discovered near Lacolle within a few miles of the international border. Very thorough measures were taken to eradicate this infestation and it is hoped that the work will prove completely successful.

The presence of this colony warns us that we must maintain a vigilant watch for the introduction of the pest. It is only through careful, very prompt and vigorous control measures that we

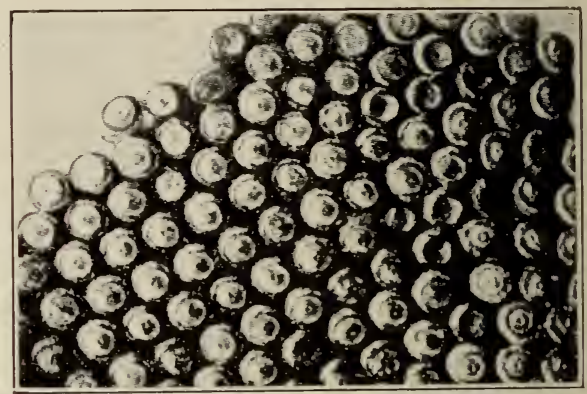

Fig. 15.-Portion of egg mass of fall cankerworm much enlarged. (After slingerland and Crosby. can hope to prevent the establishment in southern Canada of this most dreaded and destructive species. Success will depend upon the prompt recognition of the insect, so that measures for it: extermination can be instituted before the infestation becomes established over a large area.

A short description of the moth and its caterpillar will be given here with an account of the habits; this together with the illustration in figure 16 will aid in identifying the species. Any specimens of egg-masses, moths or caterpillars suspected of belonging to the gypsy moth should be reported at once to the Dominion Entomologist, the specimens being retained safely until mailing directions are received.

The female moth is stout, eream-coloured, with dark zigzag lines on the wings, which are are about 2 inches in expanse. Although well developed the females are unable to fly. The male moth, an active flier, is smaller and more slender than the female, brownish-yellow, varying to greenish-brown in colour with dark markings. The eggs are deposited in flattened, elongate masses. containing several hundred individual eggs in each, on tree trunks, stone walls, buildings and similar places. Each egg-mass is covered with the buff-coloured hairs from the underside of the female's body. 


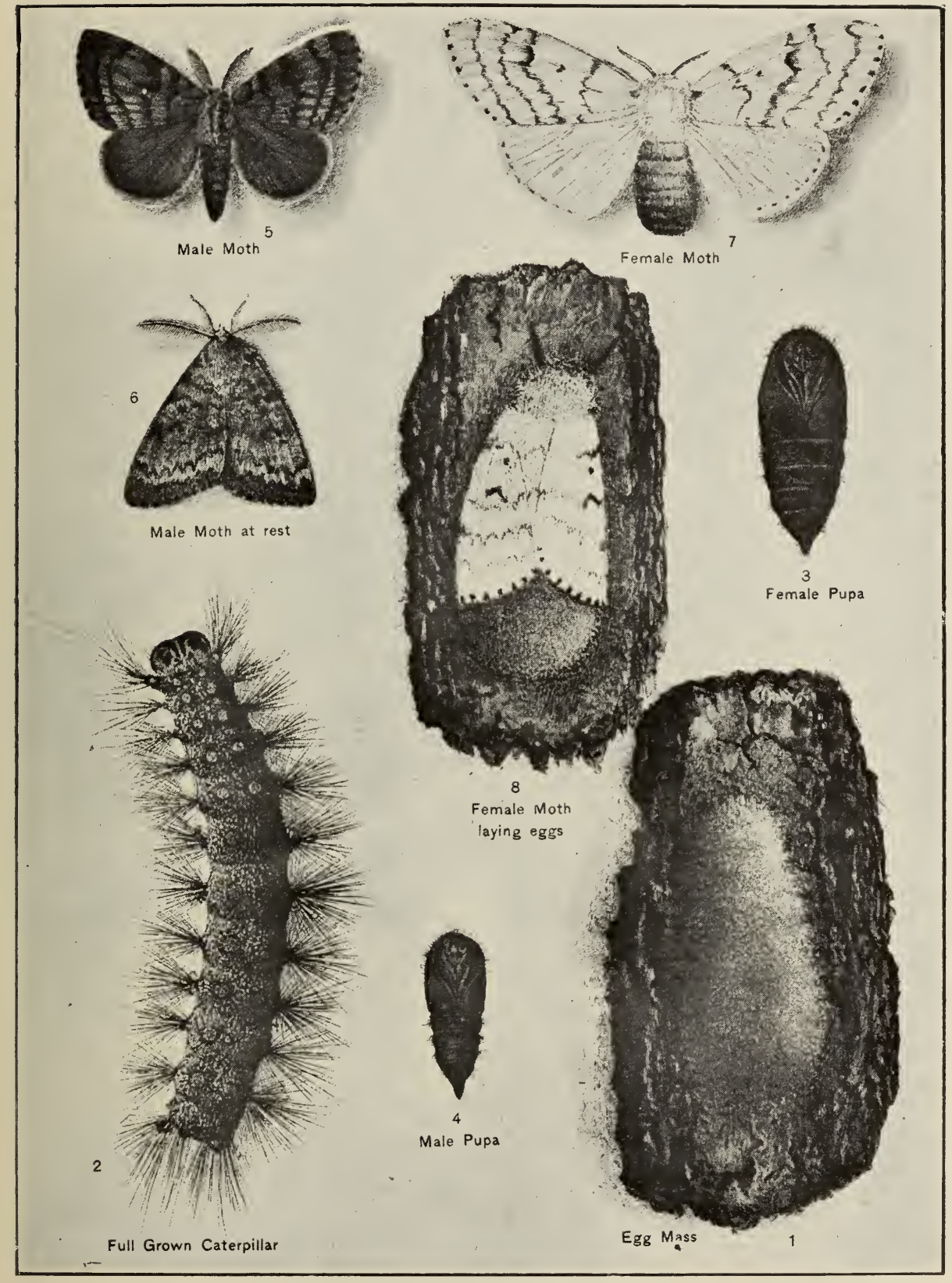

FIG. 16.-Gypsy moth. (After Rane.) 
The caterpillar is about two inches long when full grown, clothed with long black and yellow hairs, the ground colour pale brown with two rows of blue and red tubercles along the back and a similar row along each side of the body.

The life history in brief is as follows: winter is passed in the oval eggmasses; hatching occurs during May and June and the caterpillars feed upon the foliage for about six weeks; when full grown they pupate as brownish chrysalids suspended by silken threads and covered by a loose web; the moths appear in middle and late July and deposit the egg-masses which hibernate and hatch in the following spring.

In severe infestations the caterpillars occur in vast numbers and may defoliate nearly all shade and ornamental trees and woodlands in the neighbourhood. Even conifers are injured when in mixed plantations. The trees are disfigured for a large part of the season and many of them are killed by repeated defoliations. Great annoyance, also, is caused by the myriads of caterpillars and egg-masses about houses and buildings. Although the female moths, as said before, do not fly, the infestation may be distributed over the country very rapidly. The young caterpillars float readily on the wind and are dispersed in this way for many miles. The larger caterpillars may be carried in automobiles and other vehicles, and the egg-masses are readily transferred on shipments of lumber, stone and like materials to which they have been attached.

It has been found that temperatures lower than 20 degrees below zero Fah., have apparently destroyed many of the eggs in exposed places, but the eggmasses situated below the snowline and in other protected locations may be expected to survive even very low temperatures.

Control.-When the gypsy moth was introduced into America its native insect enemies were left behind and it is probably on that account that it has proved so much more destructive on this side of the water. For a number of years the United States Government have been importing European parasites of the gypsy moth in great numbers and have introduced them under the most favourable conditions into the infested area of New England. Several of these parasites have been imported into Canada and bred in our parasite laboratory to be liberated later in infested areas. The beneficial effect of this work is alyeady apparent and its importance and value should greatly increase in future years.

Control operations include the destruction of egg-masses during the dormant season by collecting them or by painting them with creosote; banding the trees to collect the caterpillars and moths; and spraying the infested foliage with arsenate of lead at the rate of 2 pounds of powder in 40 gallons of water, when the caterpillars are small, or at the rate of 3 pounds in 40 gallons, if they are nearly half grown.

\section{The Brown-tail Motir}

\section{(Euproctis chrysorrhoea Limn.)}

This insect was introduced into Massachusetts from Europe about 1897 , and has since become an important enemy throughout a large part of the New England States. It was recorded in New Brunswick in 1910, and subsequently spread to many parts of that province and into Nova Scotia. A vigorous attempt was made by the Dominion and Provincial Governments to check the infestation by destroying the winter nests of the caterpillars. Although the work is still being conducted on a small scale in the Annapolis Valley of Nova Scotia, the infestation there has been greatly reduced, while the insect has practically disappeared from the Province of New Brunswick.

The adult insect is a pure-white moth with a reddish-brown tuft on the end of the abdomen; it has a wing spread of $1 \frac{1}{2}$ to $1 \frac{3}{4}$ inches. The eggs are deposited in masses, each containing about 200 eggs, covered with brownish hairs from the abdomen of the female and attached to the underside of the leaves. The caterpillars are about $1 \frac{1}{2}$ inches long when mature, dark brown in colour, with brown 
and white hairs arranged on the tubercles. The hairs are barbed and poisonous, giving rise to an irritating rash on contact with the skin. The caterpillars pass the winter partly grown in a winter nest formed of neighbouring leaves fastened together and to the twig with silk. In the spring the caterpillars resume feeding on the foliage. They become full-grown by the first of July and pupate in crevices, the moths appearing therefrom about three weeks later to mate and

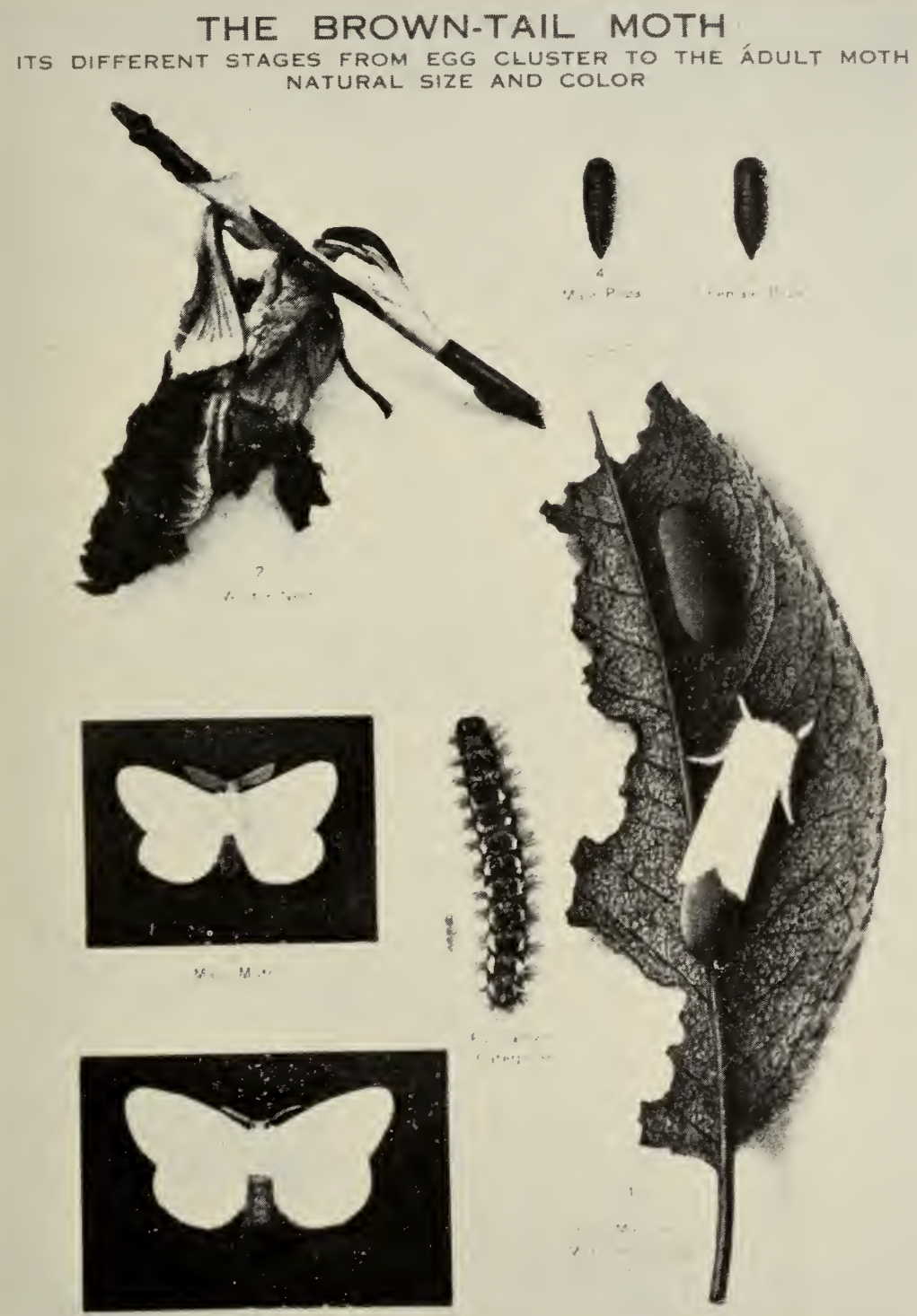

FIG. 17.-Brown-tail moth. (After Rane.)

deposit their eggs. The young caterpillars appear in late summer and feed for several weeks before constructing their winter nests. The moths fly very long distances and the species is thus capable of rapid distribution.

The caterpillars feed upon fruit trees and many deciduous trees, particularly the maple, oak and elm; when abundant they are very destructive. 
Control.-Collecting and burning the nests during the winter months is an effective method of control. When necessary this is supplemented by spraying the infested foliage in August while the caterpillars are small with powdered lead arsenate, 2 pounds in 40 gallons of water. If spraying is delayed until spring the strength of the arsenical should be doubled.

\section{The Spiny Elm Caterpillar}

\section{(Aglais antiopa Linn.)}

This is the caterpillar of the common mourning-cloak butterfly. It feeds on the foliage of elm, willow, poplar, birch, and basswood, and sometimes

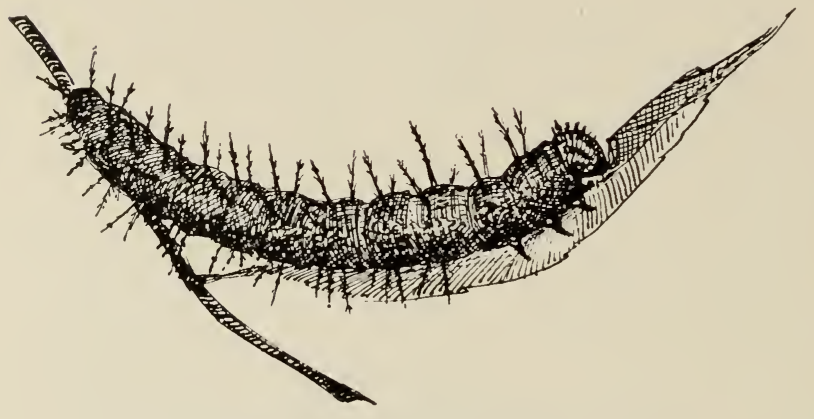

Fig. 18.-Spiny elm caterpillar (After de Gryse.) causes serious defoliation.

The caterpillar is about 2 inches long when full grown, black, sprinkled with small white dots and marked with a row of large red spots along the middle of the back and on the base of the abdominal legs. Each body segment bears several black, branched, dangerous-looking though harmless, spines. They feed in groups, during the early part of their life and later disperse over the tree, pupating finally as chrysalids, attached by the hinder end to branches, or any convenient solid object. The butterfly is dark maroon in colour with a yellow border about the wings within which is a row of blue spots. The eggs when first laid are yellow and turn black before hatching. They are deposited in bands on the twigs. There are two generations, the first in July, the second in September. These insects pass the winter in the adult stage in protected places and appear in the following spring among the earliest butterflies of the season.

Control.-When control measures are required, spray the infested foliage with arsenate of lead at the usual strength.

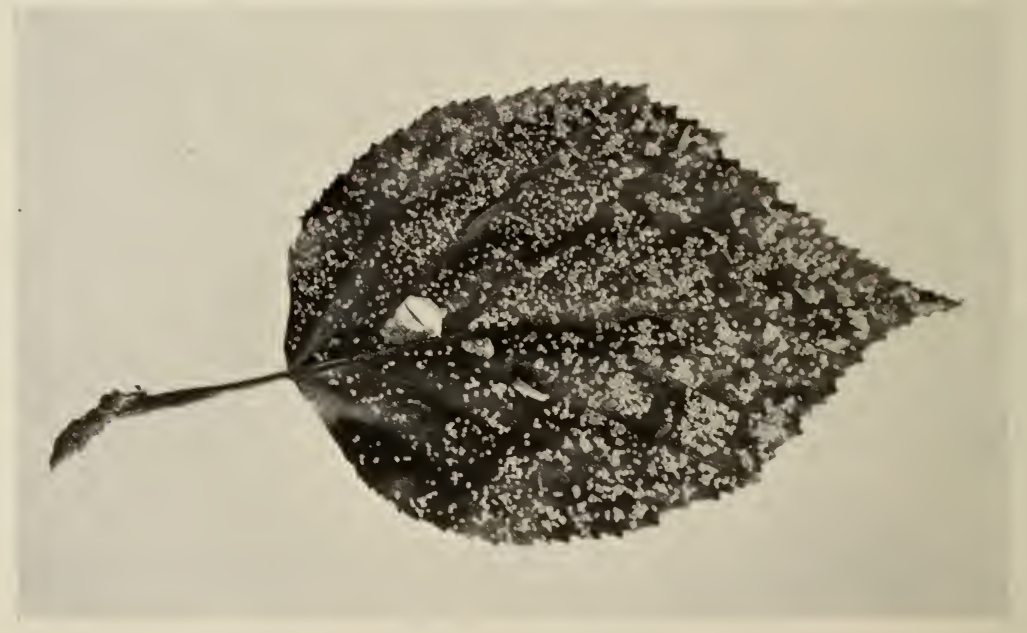

FIG. 19.-Work of birch leaf skeletonizer. (Original.) 


\section{The Birch Leaf Skeletonizer}

\section{(Bucculatrix canadensisella Chamb.)}

This insect is commonly found on birches, chiefly the white and yellow, throughout Eastern Canada and occasionally becomes epidemic. From 1921 to 1923 a severe outbreak occurred throughout a large part of Ontario, Quebec and the Maritime Provinces.

The yellow-green caterpillars, less than one-fourth of an inch in length, occur in late summer and skeletonize the birch leaves, causing severe defoliation when very abundant. Upon hatching, the young larvae mine between the upper and lower surfaces of the leaves; they then spin small but conspicuous, flattened, white, silken moulting-cocoons, attached to the leaves. After attaining full growth the larvae lower themselves by fine threads to the ground and spin tiny, ribbed, boat-shaped, silken pupating-cocoons on the underside of leaves or other protecting objects among the leaf litter. The small, light-brown moths appear towards the middle of the following July and deposit eggs on the underside of the leaves.

Control.-Injury to cultivated birches may be prevented by spraying the infested foliage with lead arsenate.

\section{The Satin Moth}

\section{(Stilpnotia salicis Linn.)}

This insect was introduced into the New England States from Europe a few years ago and has since spread over a large area in the States of Massachusetts and New Hampshire. In 1920 an infestation was discovered at New Westminster, B.C., and the infested area now extends to the city of Vancouver, and along the east coast of Vancouver Island.

The caterpillars feed on the foliage of poplars and willows. In British Columbia the injury has consisted of a partial defoliation of poplars in towns and villages, during the early season, but has not yet been particularly severe.

Hatching occurs in July and August; the young larvae feed for a short time and then hibernate in silken cases in crevices in the bark, or elsewhere. They emerge about the end of the following April and feed upon the foliage until July and pupate when full grown. They are black in colour with a row of white spots along the back.

The pure-white moths appear from the first of July onward. (See fig. 20). Control-'Spraying with lead arsenate will prevent serious injury.

\section{The White-Marked Tussock Moth}

\section{(Hemerocampa leucostigma Sm. and Abb.)}

The larvae of this species feed voraciously on the foliage of a number of deciduous shade trees specially the maple, basswood and elm. They are particularly numerous and very injurious about cities and towns.

The caterpillar is beautifully marked, with a coral red head, a yellow band along each side, and a row of four conspicuous brush-like tufts of white or yellow hairs along the back. They hatch late in May, or early in June, and at once begin feeding upon the leaves. The caterpillars frequently drop to the ground from defoliated branches and seek other trees. Towards the latter part of July they pupate in cocoons attached to the bark of the trunk and branches or to nearby objects, and about two weeks later the adult moths appear. The female is wingless and deposits several hundred eggs in a conspicuous whitish mass upon the cocoon from which she has emerged. In this latitude the eggs mostly remain upon the trees unhatched until the following spring.

Outbreaks of these caterpillars occur periodically in many of our cities and towns, usually giving rise to considerable alarm, and were their ravages allowed to increase unchecked we should lose our finest shade trees. 


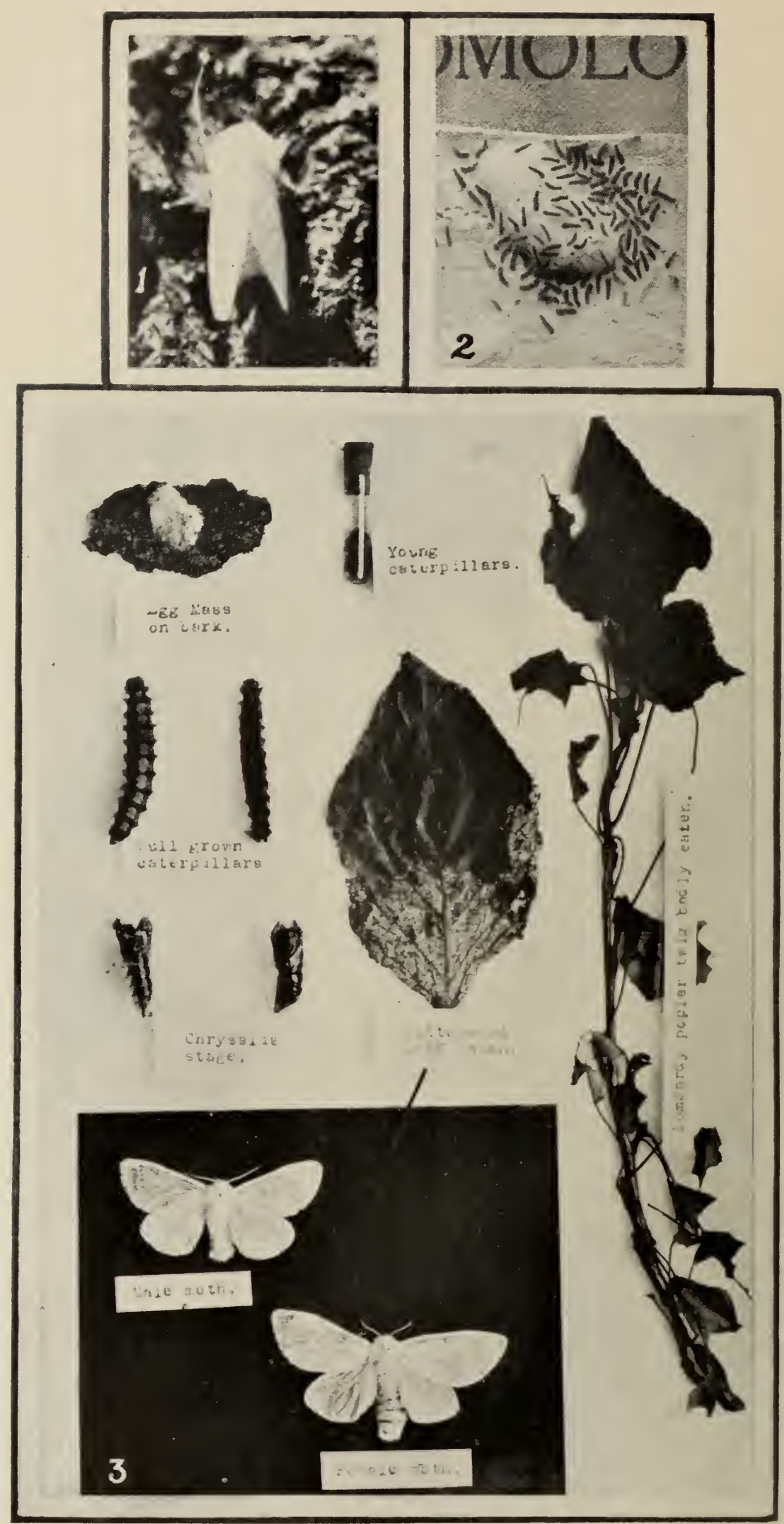

FIG. 20.-Satin moth. 1. Moth on poplar trunk. 2. Larvae hatching from egg-mass. 3. Life-history stages. (After Glendenning.) 
Fortunately, the caterpillars are attacked by many insect parasites, and often these beneficial insects succeed in destroying the caterpillars before the most serious injury has been caused. Nevertheless, many valuable trees suffer very severely in these outbreaks.
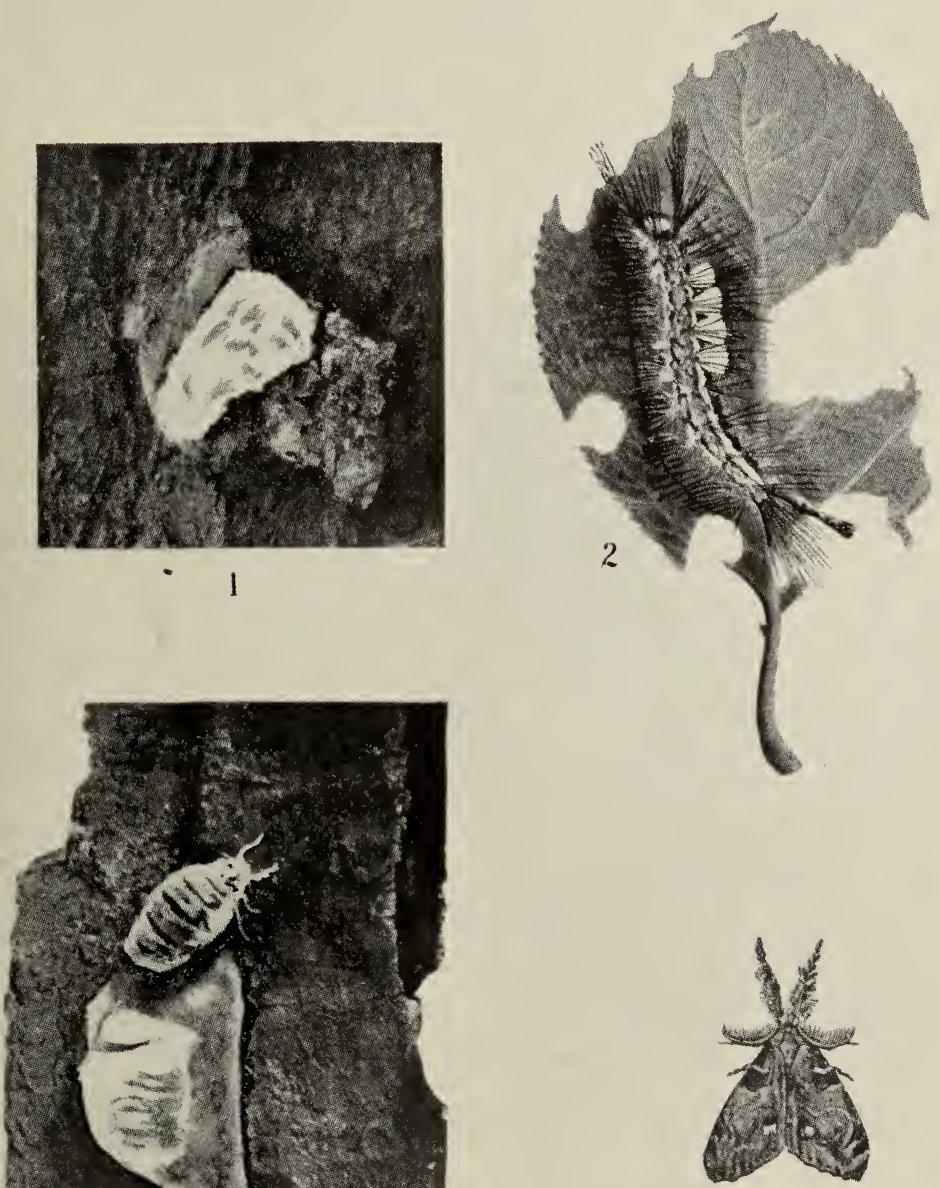

Fig. 21.- White-marked tussock mott. 1. Egg-mass. 2. Caterpillar. 3. Wingless female on egg-mass. 4. Male moth. (From Bulletin 312, Geneva Agric. Exp. Station.)

Control.-The infested foliage should be sprayed with lead arsenate powder, 2 pounds in forty gallons of water, while the caterpillars are small, before much of the foliage is injured. One thorough spraying should be effective unless the poison is washed off immediately by heavy rains. 
A simple and effective method on small trees is to collect and destroy the egg-masses. These are whitish and easily detected upon the bark after the leaves have fallen. Valuable parasites breed within the eggs and in order to avoid destroying many of these it is better to collect the egg-masses in the early spring, before the eggs hatch in May, and to leave them in loose containers at a considerable distance from valuable trees until July. The more valuable trees should be further protected from wandering caterpillars by banding with cotton batting or "tree tanglefoot." Perfect removal of the egg-masses (impracticable on large trees) or thorough spraying with lead arsenate as soon as the caterpillars appear, combined with banding the trunks, will protect isolated trees.

\section{The Fall Webworm}

\section{(Hyphantria cunea Drury)}

The conspicuous, unsightly webs of this species are usually abundant throughout many parts of Eastern Canada during the latter part of the season.

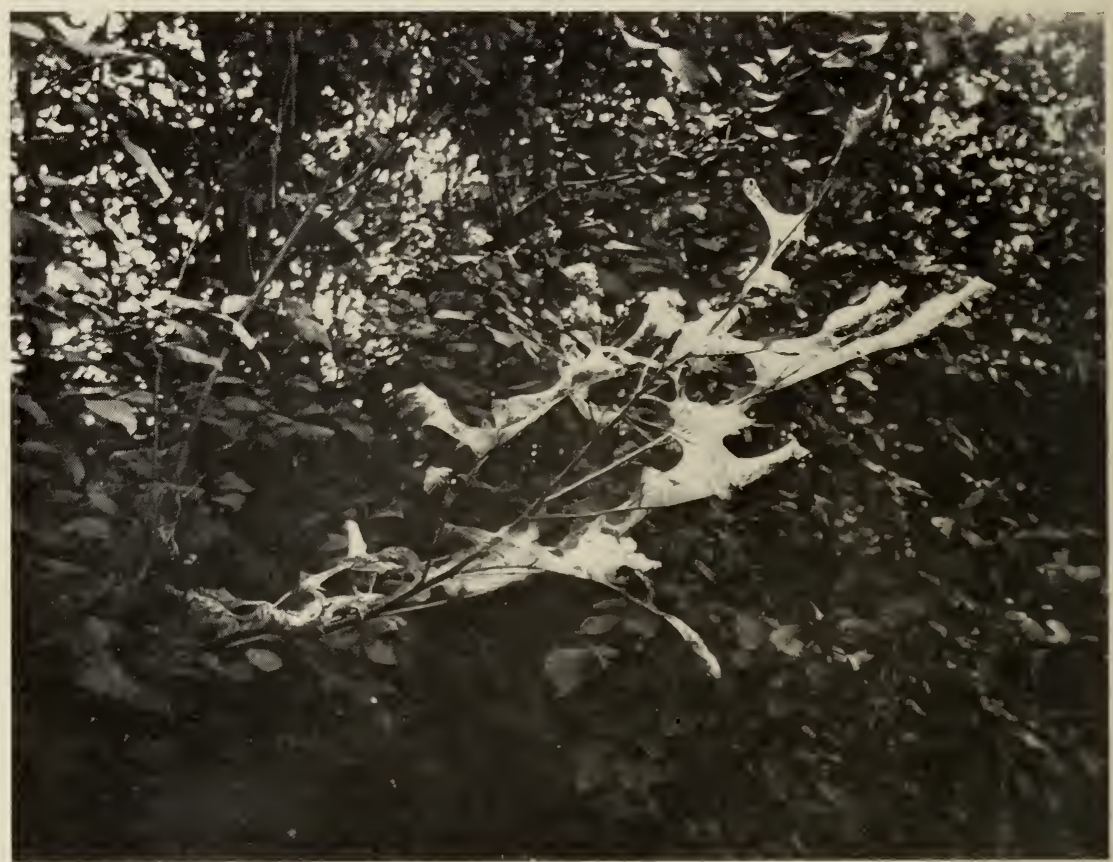

FIG. 22.-Webs formed by caterpillars of fall webworm. (After Tothill.)

The caterpillars feed collectively upon many varieties of deciduous trees, particularly the ash, elm and willow, and cover the foliage with an irregular, silk-webbing, often extended to cover the entire branch, causing injury and disfigurement to the trees.

The caterpillars are about $1 \frac{1}{2}$ inches long when full grown, distinctly clothed with whitish hairs arising from black and orange warts scattered over the body; pale yellowish or greenish in colour, with a wide, dark stripe along the back and a yellow band along the sides. In the latter part of the summer the caterpillars become full grown, descend to the ground, spin thin cocoons under rubbish or beneath the surface of the ground, pupate therein, and emerge as small white moths early in the following summer. The moths deposit vellowish eggs on the underside of the leaves and the caterpillars appear therefrom in a little more than a week. 
The webs of the American tent caterpillar with which this injury is frequently confused occur early in the season.

Control.-The webs may be removed while very small by stripping off by hand, or by means of tree-trimmers, and the contained caterpillars destroyed by crushing or burning. Burning the webs by means of a torch made of a bundle of rags attached to the end of a pole and saturated with kerosene may be used effectively. The most satisfactory method of control is to spray the infested branches with arsenate of lead at the usual strength.

\section{The Hickory Tussock Moth}

(Halisidota caryae Harr.)

The black and white hairy caterpillars of this species are occasionally abundant on elm, birch, ash and other hardwood trees. The young caterpillars are gregarious and frequently defoliate an entire branch; the larger ones feed individually.

Control.-They can be controlled by spraying with lead arsenate.

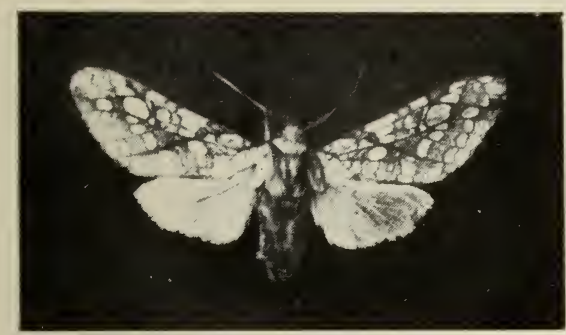

FIG. 23.-Hickory tussock moth.

(After Swaine.)

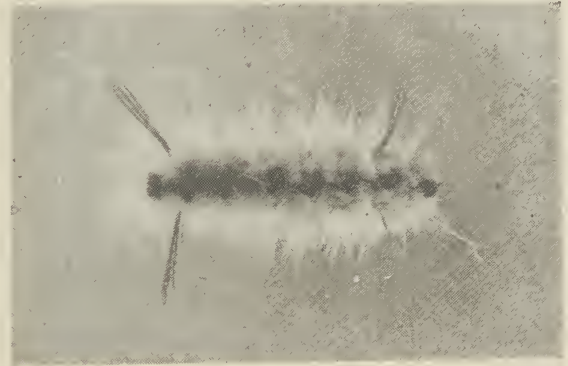

FIG. 24.-Hickory tussock caterpillar.

(After Swaine.)

\section{The Spotted Tussock Moth}

\section{(Halisidota maculata Harr.)}

The caterpillars of this species are covered with tufts of bright black and yellow hairs; they are general feeders, but prefer oak, willow and poplar.

Control.-They can be controlled by spraying with lead arsenate.

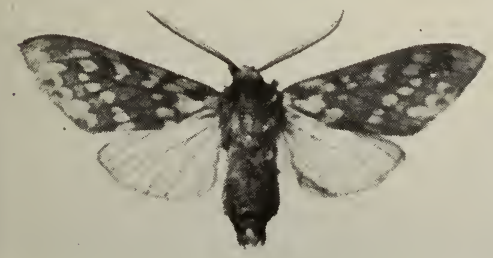

FIG. 25.-Spotted tussock moth. (After Swaine.)

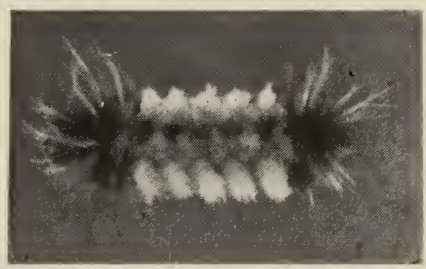

FIG. 26.-Spotted tussock caterpillar. (After Swaine.) 
The Black Walnut Caterpillar

(Datana integerrima Grote and Robinson)

The black walnut caterpillar is sometimes abundant on black walnut, butternut and hickory. The caterpillars are black, about two inches in rength when full-grown, covered with long white hairs, and have the habit of turning up both ends of the body when disturbed. They feed in large groups and sometimes cause considerable defoliation.

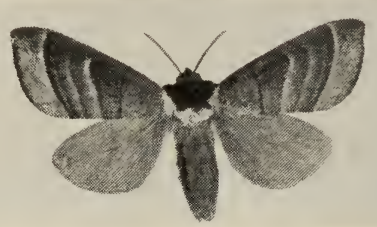

Fig. 27.-Moth of walnut caterpillar, slightly reduced. (After Hutchings.)

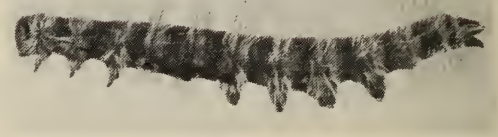

FIG. 28.-Walnut caterpillar. (After Hutchings.)

Control.- Spray the foliage with lead arsenate, or collect the larvae when they settle on the trunk or branches, in dense masses to shed their skins.

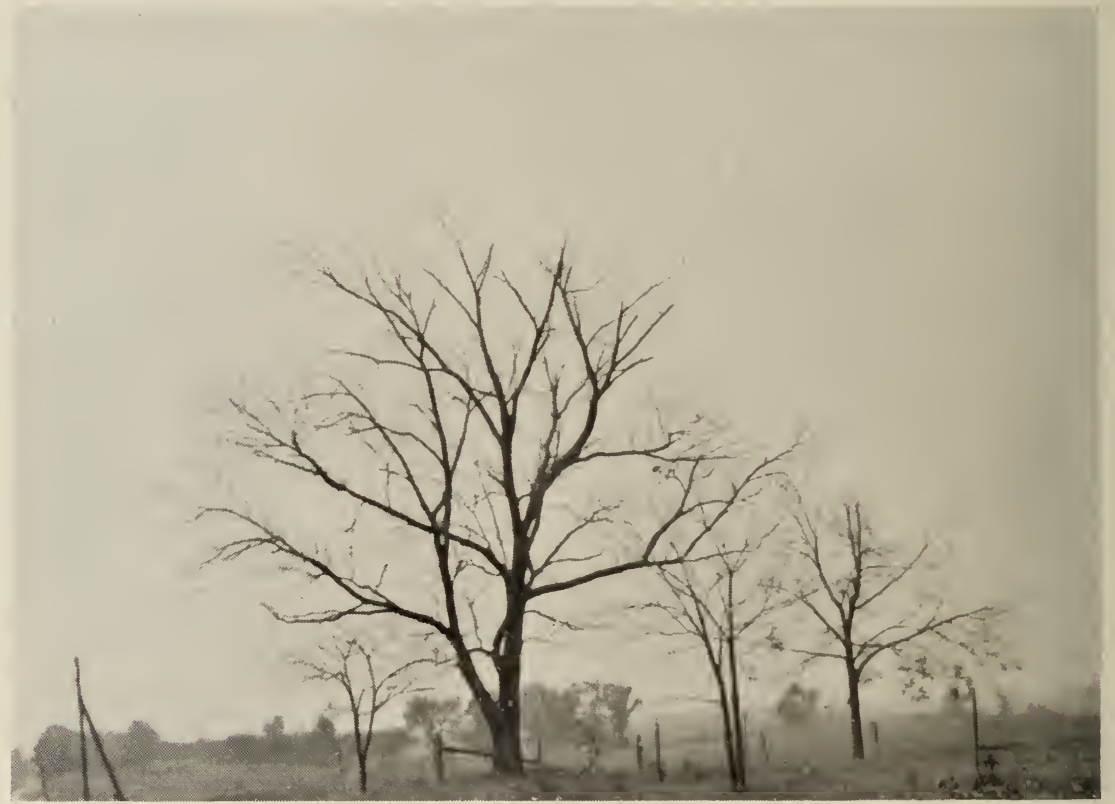

FIG. 29.-Walnut trees defoliated by caterpillars. (After Hutchings.)

The Yellow-necked Caterpillar

(Datana ministra Walk.)

The caterpillars of this species, while they have a preference for the apple, are general feeders on shade trees, particularly maple, elm, walnut, hickory and butternut.

They are black in colour, striped with narrow, yellow, longitudinal lines, and with a bright yellow neck. This last characteristic gives the insect its name. Jike their near relative, $D$. integerrima, they live in groups. This is particularly 
noticeable during the moulting periods. The moth is reddish-brown and nearly two inches in wing expanse. Eggs are laid in June.

Control.-Same as for the black walnut caterpillar. See previous paragraph.

The Spruce Budworm

(Cacoecia fumiferana Clem.)

The spruce budworm is an important forest enemy in Eastern Canada and has been reported as injuring ornamental spruce, balsam and hemlock. The small caterpillars feed upon the opening buds, and later upon the needles, which they tie together with silk. The injury to many buds checks the season's growth, and the dying, partly-eaten leaves, with the excrement and silk spun irregularly by the larvae, give the trees a scorched appearance and detract largely from their beauty.

Control.-Spray with lead arsenate as soon as the injury becomes apparent. This method applies only to trees valuable enough to warrant individual treatment.

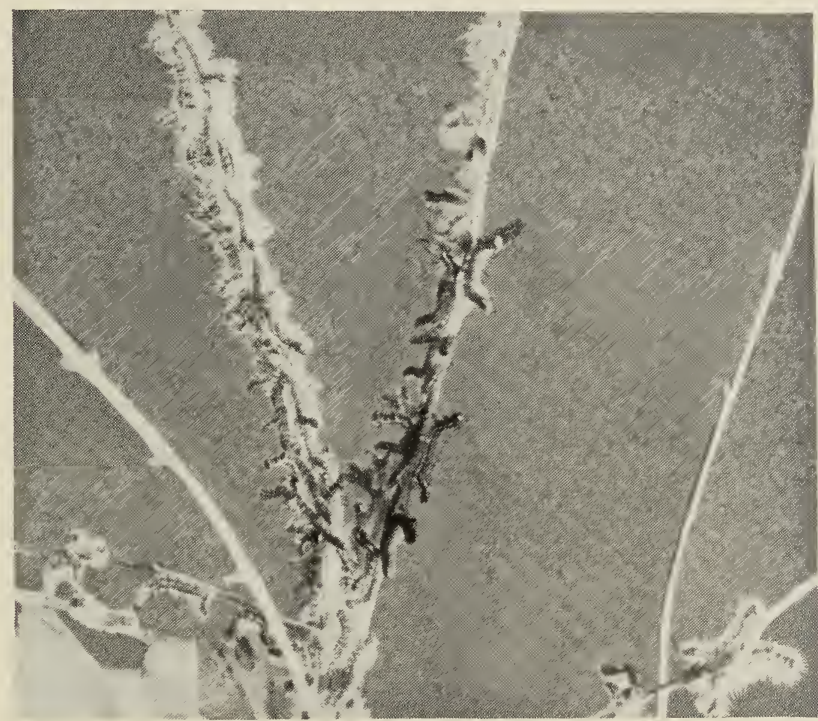

FIG. 30.-Mass of yellow-necked caterpillars in characteristic pose. (After Hutchings.)

\section{The Green-striped Maple Worm}

(Anisota rubicunda Fabr.)

Red-headed caterpillars, 11/2 inches long, yellowish-green with dark green stripes, and armed with short, black spines on each segment and two long. black horns on the second segment behind the head, occur at times in great numbers on maples.

The Yellow-striped Oak Caterpillar

(Anisota senatoria Sm. and Abb.)

Black, yellow-striped caterpillars, about 2 inches in length, with black points on each segment and two, long, black horns from the second segment behind the head, are often abundant in June and July on oaks.

\section{The Red-humped Oak Caterpillar}

(Symmerista albifrons Sm. and Abb.)

Caterpillars, nearly 2 inches long, striped with black, yellow and lilac, with a large red hump on the eighth abdominal segment, are sometimes common on oak, maple and beech late in the summer.

\section{The Antlered Maple Caterpillar}

\section{(Heterocampa guttivitta Walk.)}

Caterpillars, $11 / 2$ inches long, marked in green, yellow and purple, occasionally defoliate maple sugar bushes and other hardwoods. A severe outbreak occurred in southern Quebec in 1922. 


\section{The Green Maple Caterpillar \\ (Xylina antennata Walk.)}

Light green caterpillars with whitish markings are sometimes abundant on soft maples and other hardwoods.

Control of Defoliating Caterpillars.-Defoliating caterpillars, such as those just named, may be controlled by spraying the infested foliage with lead arsenate, $1 \frac{1}{2}$ pounds of powder in 40 gallons of water.

\section{The Larch Case-Bearer}

\section{(Coleophora laricella Hubn.)}

This insect sometimes disfigures ornamental larches, specially in Eastern Canada where it may be considered an injurious pest. The larva of the casebearer is a tiny caterpillar of most interesting feeding habits. It begins operations by eating out a portion of a larch needle which it then cuts off, lines with silk, and carries about with it as a portable house, covering the hinder part of its body. Leaf after leaf is then excavated through a round hole cut in the side by the caterpillar to permit the entrance of its body. The caterpillars retire to the twigs before the needles drop in the fall, and pass the winter in their cases, which are firmly attached to the bark with silk.

Where the attack is severe the dried and yellow excavated needles sadly disfigure the trees, and at times an injurious loss of foliage results.

Control.-The injury may be prevented by spraying trees which were badly infested the preceding season and upon which the winter cases are numerous, with lead arsenate spray just as the young needles are appearing in the spring. Later in the season poison sprays will not be so effective, owing to the small extent of leaf surface eaten by the caterpillars; but an application of kerosene emulsion, one part of the stock solution to nine parts of water will kill a great number of them.

\section{The Larch SAWfly}

\section{(Lygaeonematus erichsonii Hart.)}

This is a very destructive enemy of native and European larches. The caterpillar-like larvae feed upon the foliage during early summer, and severe defoliation for several years in succession weakens and eventually kills the trees. The curved twigs, caused by egg-scars, and the bare and brownish appear-

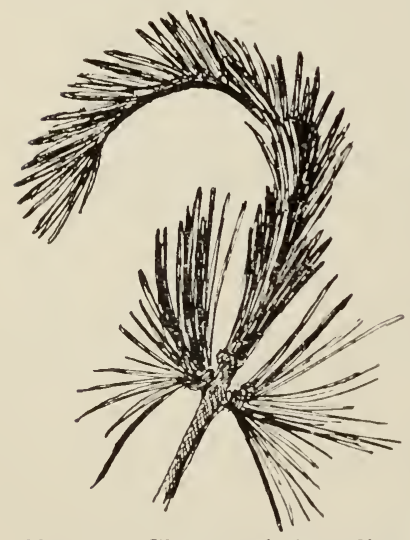

FIG. 31.-Characteristic curling of end shoot raused by the egg-laying adult of the larch sawfly. (After de Gryse.) ance of the trees in summer, distinguish the injury.

The larvac are two-thirds of an inch long when full grown, greenish in colour, the head black, the body usually curved like a bent finger. The adult insect is a dark, four-winged fly, appearing early in spring to deposit its eggs in a row of slits along one side of the developing shoots, causing the latter to curl in a characteristic manner. The larvae pass the winter in oval, tough, brown, silken cocoons, two-thirds of an inch in length, in the moss beneath the trees.

Control.-The larvae feed in clusters and on a few small trees may be hand picked and destroyed by crushing or dropping into a pail of water and kerosene.

When many trees are involved it is necessary to spray the infested foliage thoroughly with arsenate of lead at the rate of $1 \frac{1}{2}$ pounds of powder in 40 gallons of water, with a little soap added. 
The Elm Sawfly

(Cimbex americana Leach)

The larvae of this sawfly feed upon the foliage of willow, elm, maple and poplar. The adults are reported to gnaw into the twigs and thus often injure the plant by girdling the stems, giving the tops a characteristic appearance of having been swept by fire.

The larvae, which resemble caterpillars, are yellowish-white in colour and have a conspicuous black line along the middle of the back. They have eleven pairs of legs, eight of which are on the abdomen. When full grown they attain a length of $2 \frac{1}{4}$ inches, leave the food plant and form their cocoons among decaying leaves or loose soil under the trees. There they pass the winter, pupate in spring and appear as large, wasp-like, four-winged flies in May. The females deposit their eggs singly in pockets cut into the leaf tissue and the young larvae hatch in about eight days.

Control.-Burning rubbish under the trees in April will destroy many of the over-wintering insects. In small willow plantations and on small trees hand picking the larvae from the infested leaves may also be effective. The most satisfactory method, however, is spraying with arsenate of lead at the rate of $1 \frac{1}{2}$ pounds of powder in 40 gallons of water, as soon as the larvae are noticed.

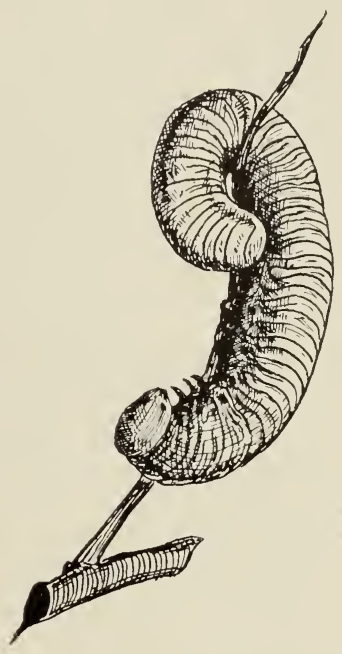

FIG. 32.-Elm sawfly larva. (After de Gryse.)

\section{LeConte's Pine SAwfly}

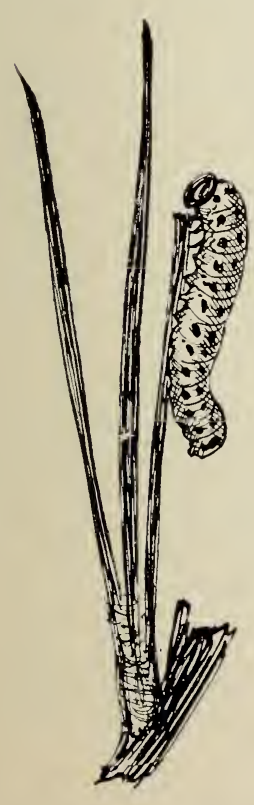

Fig. 33.-LeConte's pine sawfly larva.

(After de Gryse.)

\section{(Neodiprion lecontei Fitch)}

Not infrequently, pines are seriously defoliated in early summer and in autumn by the larvae of this sawfly, which are found feeding in clusters in July and sometimes in September and October. They are of a dirty yellowish colour with the head reddish and black spots along the back and sides. When full grown they crawl to the ground and pupate in tough, silken cocoons under rubbish. The winter is passed in this condition. The adults, dull, tawny-yellow, four-winged flies, first appear in May and lay their eggs in slits in the needles.

Control.-In small plantations and on isolated small trees remove the larvae by hand and crush them or drop them into a pail of water and kerosene. When larger areas and trees are involved spray the foliage with arsenate of lead at the rate of $11 / 2$ pounds of powder in 40 gallons of water, with a small amount of soap added.

\section{Abbott's Pine Sawfly \\ (Neodiprion pinetum Norton)}

The larvae of this species are nearly an inch in length, the head black, the body yellowish with four longitudinal rows of black spots. They feed on the foliage of pines and have habits similar to those of LeConte's sawfly.

Control.-The same as for LeConte's sawfly. (See above.) 


\section{The Fir Sawfly \\ (Neodiprion abietis Harris)}

In this species the larvae are striped with dark green, with a black head, about half an inch long when full-grown, found feeding in midsummer on fir

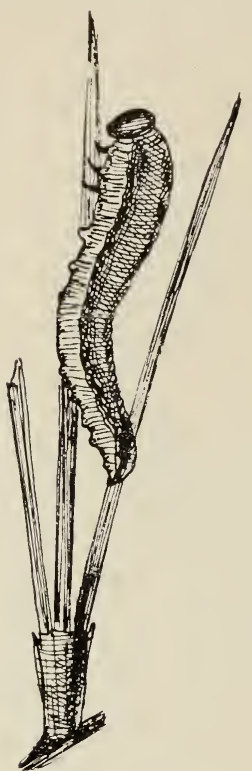

FIG. 34.-Fir sawfly larva.

(After de Gryse.) and spruce.

Control.-The same as for LeConte's sawfly. (See above.)

\section{The Alder Leaf-miner \\ (Kaliosysphinga dohrnii Tisch.)}

This srecies, closely allied to the elm leaf-miner and with similar habits, is abundant about Ottawa on cultivated alders. The adults appear and deposit eggs in the leaves during late May or early June and again in July, and flies have been seen ovipositing in September.

Control.-The injury is prevented readily by spraying the infested foliage, as soon as the mines appear, with kerosene emulsion at the rate of one part stock solution in five parts of water; one part stock to seven parts of water is effective when applied immediately after the eggs are hatched.

The following varieties of alder have been found immune from attack: Alnus serrulata, A. carpinus betula, A. oblongata and A. macrophylla.

\section{The ELM LEAF-MINER}

\section{(Kaliofenusa ulmi Sund.)}

This recently introduced elm pest has become established in southern Ontario and southern Quebec. The larvae excavate bloteh mines in the leaves of elms and when abundant they destroy a large part of the foliage and render even large trees unsightly for a gleat part of the summer. (See fig. 36).

The adults, small black sawflies about one-eighth of an inch in length, appear late in May and deposit their eggs through the upper epidermis of elm leaves. The legless larvae extend their mines between the two surfaces of the leaf, producing a characteristic blistered appearance. Attaining full growth about July 1 they leave the mines and spin small silken cocoons below the surface of the ground, within which they pass the winter, and transform to the pupae and then to the adults in the following May. There is reported to be only one generation each year.

Control.-The injury can probably be prevented on trees raluable enough to warrant the treatment by spraying in early June, as soon as the minute blisters appear, with nicotine sulphate and soap, or with kerosene emulsion, one part of the stock solution in seven parts of water.

\section{The European Poplar Sawfly \\ (Trichiocampus viminalis Fabr.)}

The larvae of this introduced insect feed chiefly on the foliage of Carolina poplars. They are yellowish with black spots, a black head and white hairs and attain a length of about three-fourths of an inch.

Control.-Lead arsenate is recommended if control is required. 


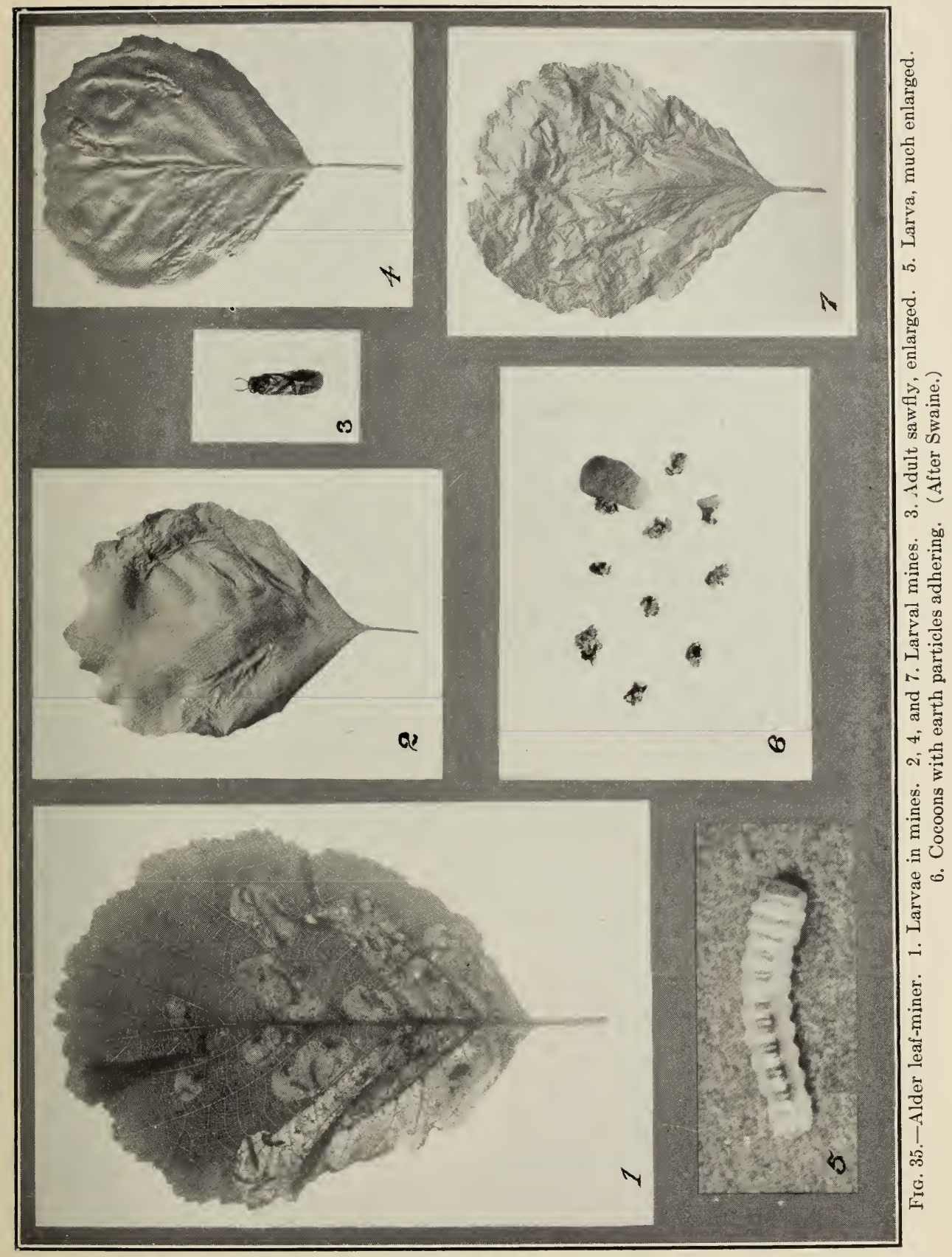




\section{The Lilac Leaf-Miner \\ (Gracilaria syringella Fabr.)}

The adult of this miner is a brown moth, $1 / 4$-inch in length, which appears early in June, during the evening hours, and lays its eggs on the underside of the young leaves. The grub is at first a miner and feeds between the upper and lower leaf surfaces, causing them to turn brown and bladder-like. Later it comes to the exterior, rolls the leaf and feeds therein, sometimes six or more

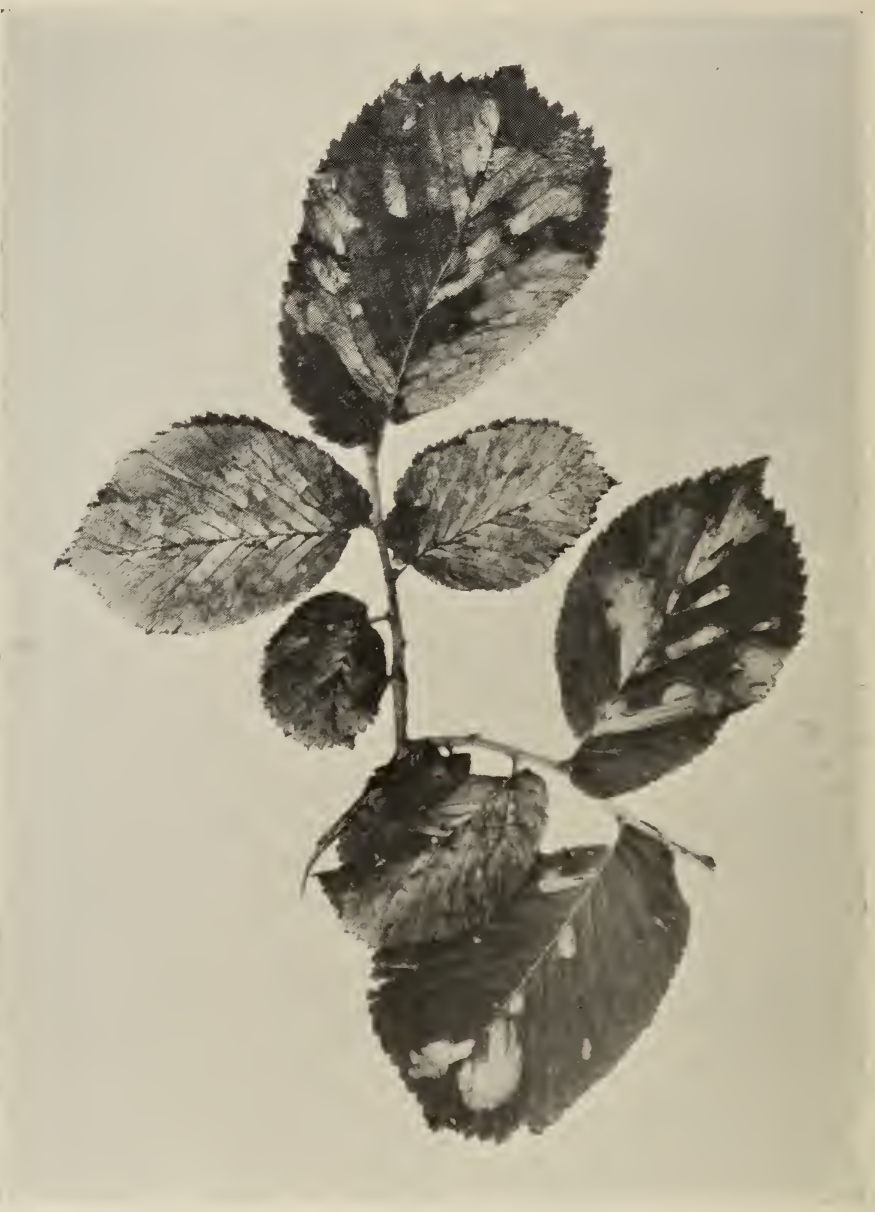

Fig. 36.-Work of elm leaf-miner. (After Chrystal.)

larvae working together. As a consequence the shrubs are badly disfigured. There is a second generation early in September, the larvae of which are even more injurious.

Control.-Nicotine sulphate should be applied when the leaves first show signs of the larval work, in the proportion of $1 \frac{1}{2}$ tablespoonfuls of nicotine to one gallon of water. Follow this with a stronger solution two weeks later, if necessary. The work should be carefully done and the branches well covered. Picking off and burning the spotted leaves early in the season will help in checking the spread of the injury. 


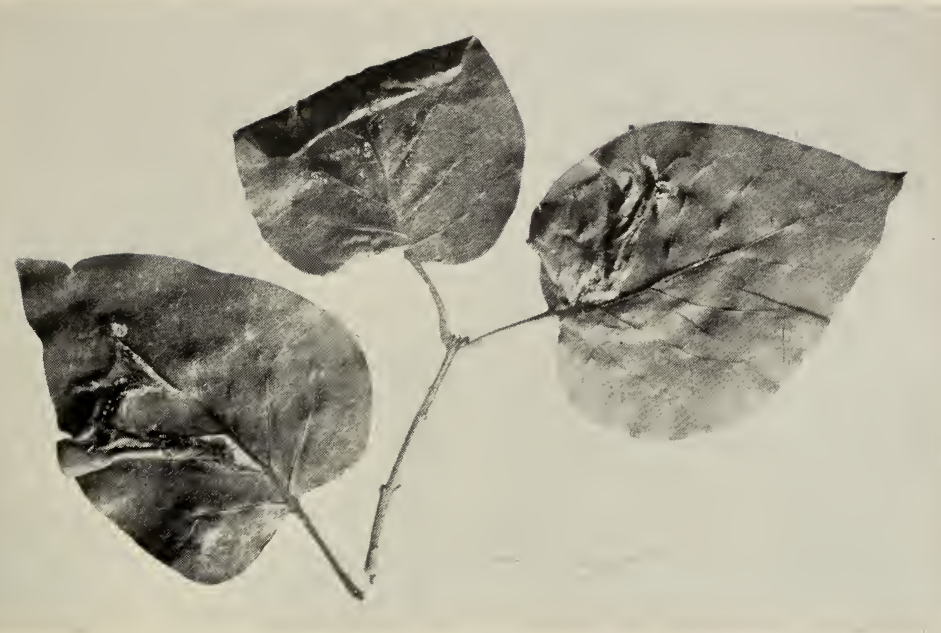

Fig. 37.-Leaves injured by lilac leaf-miner. (Original.)

The Yellow-spotted Willow Slug

(Pteronus ventralis Say)

This is one of the worst enemies of the willow, particularly to young growth. Swellings on the upper sides of the leaves indicate the spots of oviposition. The eggs produce black, slug-like larvae which feed in groups on the foliage, stripping it completely. Pupation occurs in two or three weeks in the ground within a dark brown, shining cocoon from which the adult fly later emerges after a week in the resting stage.

Control.-Whenever abundant this species can be controlled by a spray of $1 \frac{1}{2}$ pounds of lead arsenate powder to 40 gallons of water.

\section{The Elm Leaf-Beetle}

\section{(Galerucella xanthomelona Schrank)}

This important enemy of both European and American elms is reported to be well distributed in the eastern United States, but has not yet been found in Canada. The greenish, black-lined beetles, about one-fourth of an inch long, and their grubs feed upon the foliage of elms during June and July.

Control-The injury may be controlled by spraying the infested foliage with lead arsenate.

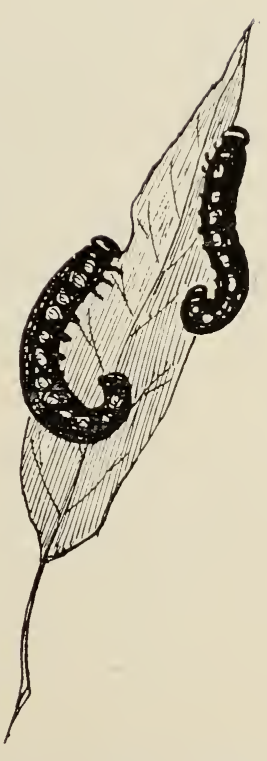

IG. 38.-The Yellowspotted willow slug;

Larvae feeding on willow.

(After de Gryse.) 


\section{The Cottonwood Leaf-Beetle \\ (Lina scripta Fabr.)}

This species is abundant in many seasons, feeding in both adult and larval stages on the foliage of poplars and willows.
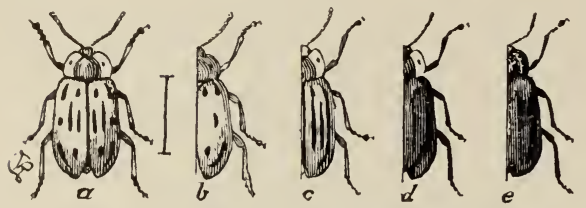

FIG. 39.-Poplar leaf beetle, showing variations. (After Riley.)

The adult is a somewhat flattened, elongate and rounded beetle, a little less than half an inch in length. The wingcovers are golden-yellow with elongate dark, longitudinal markings, varying to nearly black throughout; the thorax is black with a reddish or yellow border; the under surface is dark green.

The yellowish eggs are laid on the undersides of the leaves and hatch in about 10 days. The grubs are about one-third of an inch long when full grown, soft-bodied, yellowish in colour with darker head and legs. They feed upon the undersides of the leaves and complete their growth in about two weeks. The pupae are attached by the hinder end of the body to the undersides of leaves and other objects. There is apparently more than one brood each season. The beetles pass the winter beneath rubbish on the ground and in protected places. They appear in May, feed upon the opening buds and foliage and deposit their eggs.

This species sometimes severely defoliates shade and ornamental trees and fields of basket willows.

Control.- Spray the undersides of the leaves with lead arsenate, 2 pounds, soap 1 pound, in 40 gallons of water. In fields of basket willows a beetle-collecting machine is recommended which brushes the beetles into pans of kerosene as it is moved along the rows.

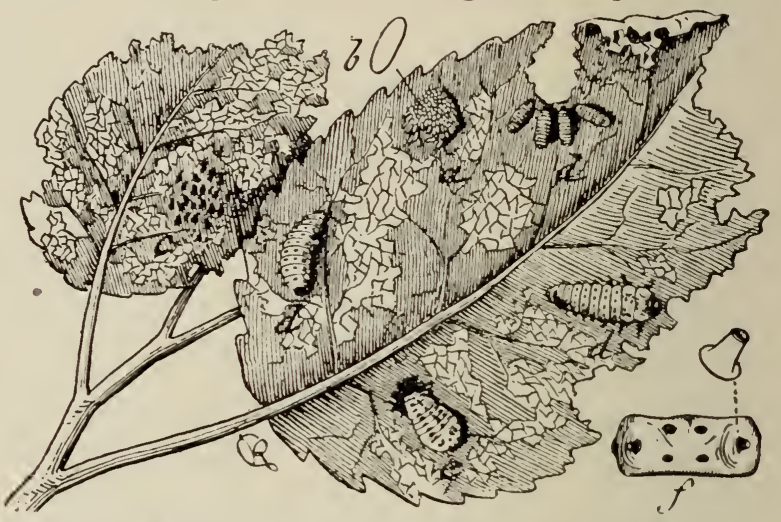

Fig. 40.-Work of poplar leaf beetle larvae. (After Riley.)

\section{The Spotted Willow Leaf-Beetle \\ (Lina interrupta Fabr.)}

This species is of the size and form of the preceding, but in colour has the wing-covers yellowish to reddish with rows of square or transverse black markings; the thorax black with a yellow or red border and the under surface black.

Its habits and life-history are much the same as described for Lina scripta.

Control.- Use the arsenate of lead spray as above.

\section{The Arboritan Leaf-imner}

\section{(Argyresthia thuiella Pack.)}

Dying tips of the leaves of white cedar, or arborvitae, are frequently caused by the mines of tiny yellowish caterpillars, one-eighth of an inch in length. The adults are very small white moths with black spots on the wings. They emerge about the first week in July and lay their eggs on the inner edges of the leaves during the middle of that month, and the larvae excavate a small area between the upper and lower leaf surfaces where they hibernate without other protection. In spring they continue feeding, reach full growth in June and pupate about the middle of the month. 
Control.-In some seasons this leaf miner disfigures ornamental cedars so seriously that control measures are desirable. Clipping off and burning the dried tips in fall or early spring would account for many larvae. Kerosene emulsion sprays have no effect, but a strong tobacco-soap solution applied in July has been recommended for young larvae.

\section{June Beetles}

\section{(Lachnosterna spp.)}

June beetles are the adults of white grubs, one of the worst pests the farmer has to combat. They feed freely on the foliage of many shade trees. The adults are robust, clumsy, reddish-brown beetles which may be found flying around lights during the warm evenings of May and June. Maximum flights occur every three years. One of these took place in 1925, maple, elm, and other trees in eastern Quebec

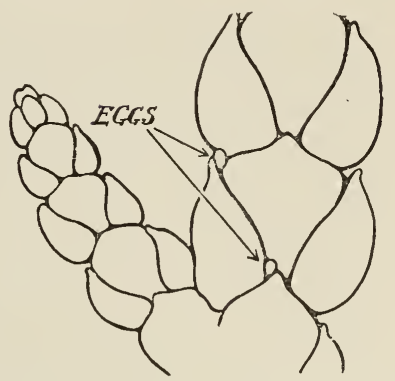

FIG. 41.-Arborvitae leaves showing location of eggs deposited by tiny moths. Much enlarged. (Original.)

being literally stripped bare by the ravages of the beetles. These flights are of short duration, and subsequently the beetles bury themselves in the earth, lay their eggs and die. The eggs hatch into tiny, white grubs which feed on the roots of plants. These remain below the ground for three seasons, transform in the fall and emerge the following May or June.

Control.-Lead arsenate, $1 \frac{1}{2}$ pounds to 40 gallons of water, applied when the beetles are first noticed will kill large numbers. Jarring the trees and destroying the beetles as they fall to the ground by drowning them in kerosene and water is to be recommended.
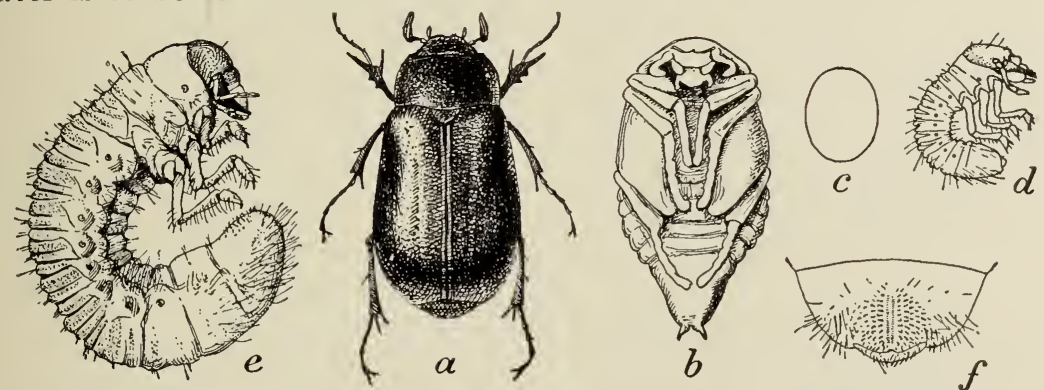

FIG. 42.-Life-history stages of June beetle. (a) beetle; (b) pupa; (c) egg; (d) young grub; (e) full grown grub; $(f)$ anal segment of same from below. (After Chittenden.)

\section{The Walkingstick Insect \\ (Diapheromera femorata Say)}

Oak, basswood, hazel, maple and other deciduous trees are attacked by this insect. It is frequently found in limited numbers in groves, woodlands and parks. Occasionally, it becomes abundant, as for example in 1904 in the Niagara district when many valuable shade trees were stripped of their foliage. It derives its name from the remarkable resemblance it bears to a leafless twig. The seed-like eggs are dropped freely on the ground where they remain for the winter. The following summer the young green nymphs crawl up the trees to the foliage above and begin feeding. They reach maturity after a series of moults in September when they attain a length of $3 \frac{1}{2}$ inches and are dark brown to green in colour. After egg-laying the adults soon die. There is but one generation a season.

Control.-As the adults are very susceptible to sudden changes of temperature, the early frosts undoubtedly play an important part in their control. Where these insects are numerous a spray of lead arsenate, 1 to $1 \frac{1}{2}$ pounds in 40 gallons of water will control them. 


\section{Giant Silk Worms \\ (Saturniidae)}

Several members of this family feed on various deciduous trees and the caterpillars often attract attention on account of their large size. They are seldom in sufficient numbers to be of any serious economic importance.

Among these species may be mentioned the cecropia larva, Samia cecropia Linn., one of the largest of caterpillars, attaining the size of four inches in length. It is green in colour with blue, yellow and red spiny protuberances on the back. It feeds on maple, basswood, elm, birch, willow, poplar, etc.

The larva of the io moth, Automeris io Fabr., also green, has a red stripe down each side and is studded with groups of black-tipped cactus-like spines which are venomous. For this reason it should be handled with care. Among the different plants it attacks are the maple, oak, elm, basswood, birch, ash and poplar.

The polyphemus, or American silk-worm caterpillar, Telea polyphemus Hubn., is somewhat smaller than S. cecropia. It may be recognized by the silvery tinted breathing pores conspicuous on the sides of its green body. It. has a wide food range and will readily eat elm, maple, ash, basswood, poplar, willow and birch.

The larva of the luna moth, Tropea luna Linn., is another general feeder. It attracts particular attention on account of its size (three inches) and of the beauty of the adult, rather than by any actual damage it may do. It has been found on walnut, hickory, oak, beech, birch, willow and other deciduous trees.

\section{WOOD BORERS}

\section{The Sugar Maple Borer}

\section{(Glycobius speciosus Say)}

This is a common enemy of sugar maples in Eastern Canada, and the injury caused by the borers is often seen on the trunks. The adult, a beautiful black and yellow beetle about an inch long, with a characteristic yellow $\mathrm{W}$-shaped

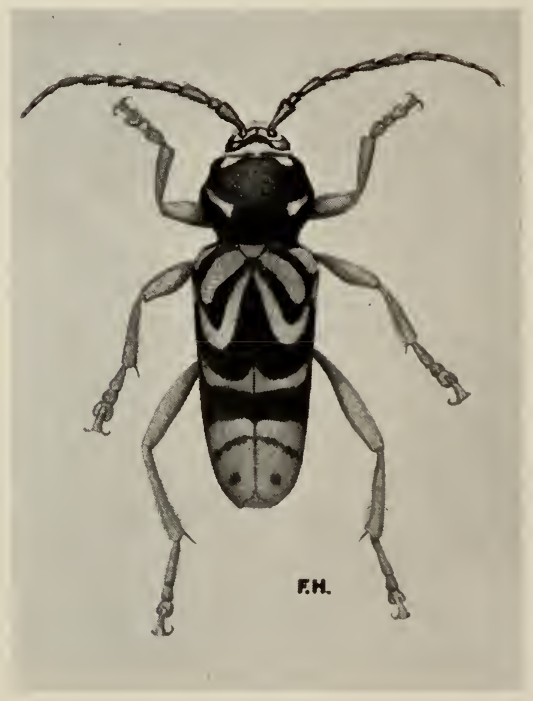

FIG. 43.--Beetle of sugar maple borer; about twice natural size. (After Hutchings.) mark on the back, deposits its eggs in midsummer in slits in the bark of the trunk, or larger branches. The legless grubs have powerful jaws and excavate shallow burrows, usually slanting upwards often several feet long, in the inner bark and sapwood. These tumnels more or less completely girdle and seriously weaken or kill the infested branches or trunks. The young grubs are betrayed in the fall by protruding "sawdust" and the tunnels of the larger borers produce unsightly scars. The grub changes to the pupa and finally to the adult beetle in the end of the tunnel, and the beetle cuts its way out through the bark by an oval hole about one-half an inch in diameter. The beetles appear in June and July to deposit their eggs for the next brood. Apparently healthy trees are attacked, and dying branches and trunks, as well as the scars referred to, are the result of its work. 
Control.-Much of the injury could be averted by examining the trees in the fall and again in the spring and cutting out the borers with a sharp knife or killing them by a wire thrust into their borings. The fresh tunnels discovered should be followed with the least cutting possible, and the borer at the end destroyed; the injury caused by the borers will eventually be more serious than the cutting necessary to remove them. The scars resulting from old tunnels should be smoothed off, and these where necessary, as well as the fresh tunnels, should be disinfected and filled with grafting wax or putty.

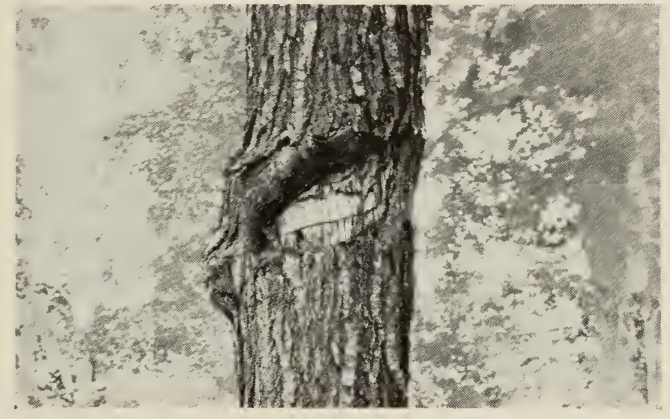

FIG. 44.- Sugar maple showing tunnel line and ugly scar, the work of the maple borer. (After Hutchings.)

\section{The Bronze Birch Borer \\ (Agrilus anxius Gory)}

This insect is the most destructive enemy of white birches in many parts of Eastern Canada. The adult is a rather slender, olive-brown beetle of metallic lustre, nearly one-half an inch in length. The grubs which cause the injury are slender whitish borers found excavating their tunnels in the inner bark of the trunk and branches of infested trees. The tunnels are very elongate and winding, and eventually girdle and kill the parts attacked. Infested trees begin to die at the top, and after a few years they gradually succumb. The location of the larvae is often disclosed by the reddish patches on the bark caused by the oxidizing sap flowing from the borings, but more often by the ringed swellings on the trunk. The adults escape to the exterior through lunar holes, so characteristic of this group of beetles. (See fig. 45.)

Control.- It is difficult to preserve white birches in localities where these beetles are abundant. At the first appearance of injury the infested tops and branches should be removed and burned before the beetles emerge from the wood, late in May or early in June, to spread the infestation. After much of the top has died from the attack of the beetles, it is hopeless to attempt to save the tree by repeated prunings since the whole tree by that time is a breeding ground for the pest, and should be cut down completely and burned, either in late fall or early spring to prevent the spread of the beetles to other trees.

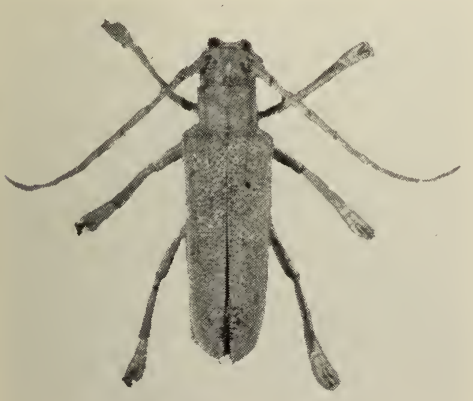

FIG. 46.-Beetles of poplar borer. (After Chrystal.)

\section{The Poplar Borer}

\section{(Saperda calcarata Say)}

Dying and dead branches and tops of aspens and other poplars are frequently caused by the large, yellowish-white grubs of this species, which excavate wide burrows deep into the trunk. Sap oozing from the tunnels and piles of frass about the base of the trees are indications of an attack.

The adults, long-horned beetles, $1 \frac{1}{4}$ inches in length, grey with yellow markings and numerous black spots on the back, appear in midsummer and lay their eggs on the bark of the trunk. The grubs live for about three years in the wood and attain a length of nearly two inches. The extensive borings kill much of the bark, permit the entrance of wood destroying fungi and weaken the trunks so that they frequently break during storms. (See fig. 49.) 


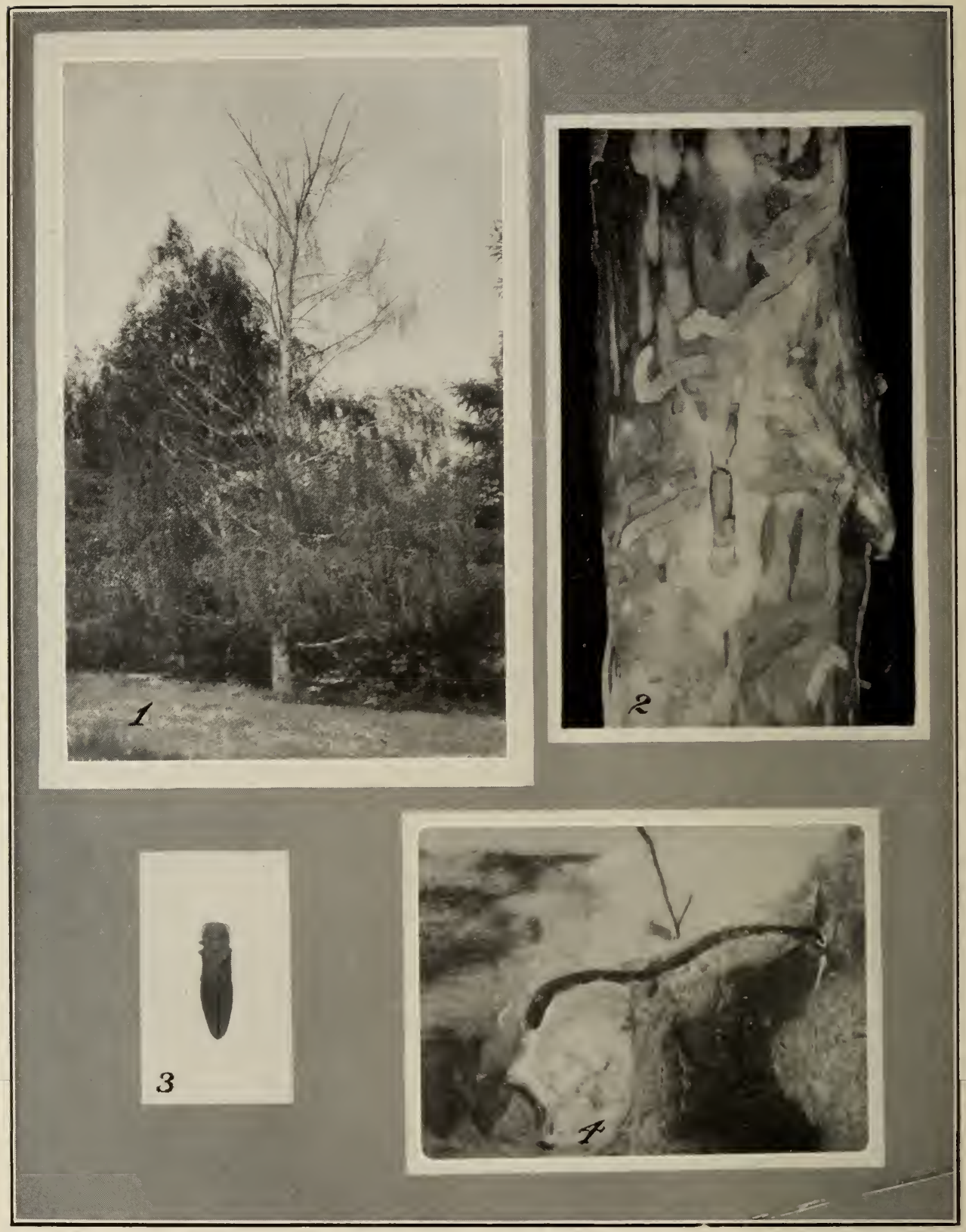

Fig. 45.-Bronze Birch Borer. 1. White birch injured by borers; top dead. 2. Larval mines, with larva in its winter cell. 3. Beetle. 4. Beginning of mine. (After Swaine.) 


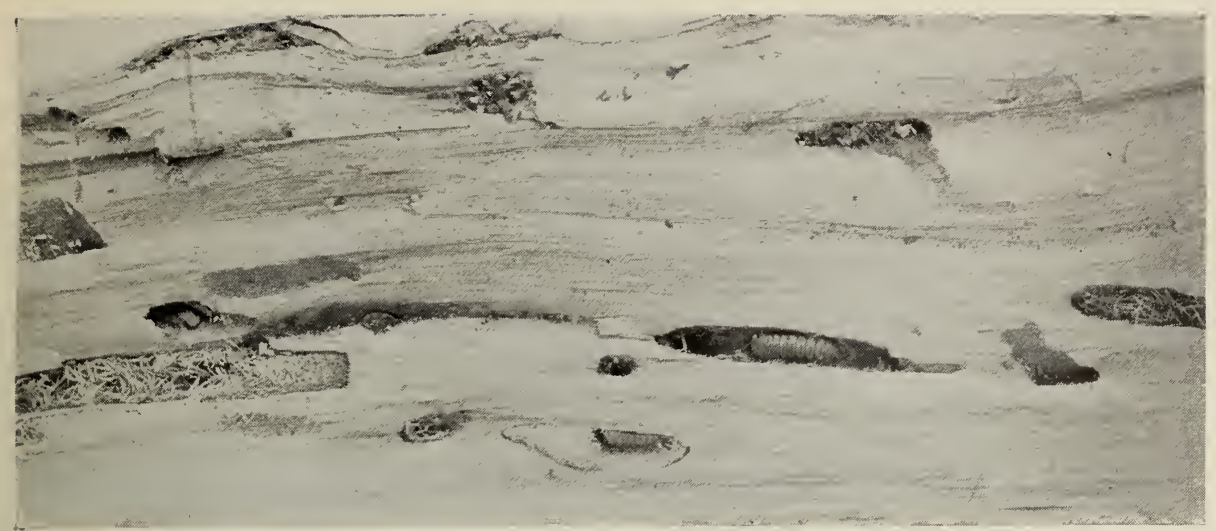

Fig. 47.--Larval mines and pupal cells of poplar borer. (After Chrystal.)

Control.-Infested trees of little value should be removed and burned before June. Valuable trees may be saved by cutting out the grubs in the early fall, or killing the borers by injecting a small quantity of benzine or carbon bisulphide into the tunnel's entrance by means of a machinist's oil can or an atomizer, and retaining the fumes with a plug of clay or putty. Cutting down and burning the most heavily infested trees (brood trees) will be found most helpful in reducing the infestation. Painting the egg scars with creosote in October has been advocated. Some benefit may be derived from the application of poisoned contact sprays.

\section{The Linden Borer \\ (Saperda vestita Say)}

Basswoods or lindens are attacked by many insects. The larva of this species is responsible for tunnelling long irregular galleries, particularly at the base of the tree. On young nursery stock this form of injury is specially severe.

The adult, which appears in midsummer, also feeds on the bark and tender, succulent parts of the leaves and branches.

It is a buff-coloured beetle with six black spots on the back, and is a little more than half an inch in length:

Control.--Remove all dying and sickly branches. Watch for any attack and destroy the beetles or young grubs at once. It is important that nursery stock be inspected systematically several times during the season for signs of the enemy.

\section{The Elm Borer}

(Saperda tridentata Oliv.)

Dying or dead branches of elm trees sometimes show indications of injury by this borer. The adult beetle is about half an inch long, grey with black spots and transverse red markings. It appears in June and deposits eggs in the bark. The grubs bore in the inner bark and sapwood for about a year. They are found in dying branches and trunks killed by fungi and also in living trees. The species is apparently more injurious in the Fastern States than in Canada. Cutting and burning badly infested trees before June will help in checking the spread of the injury.

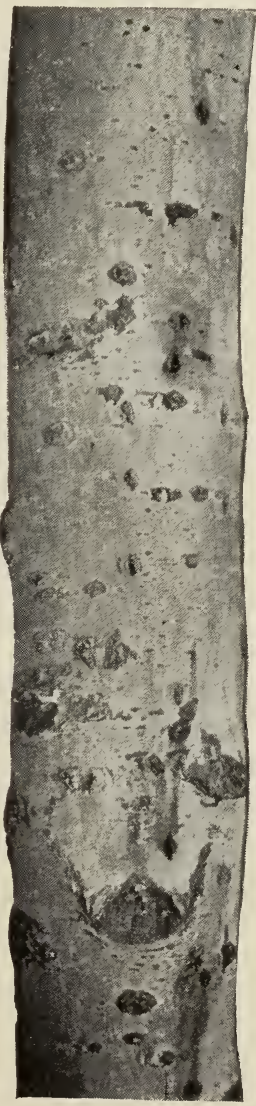

Fig. 48.-Scars on bark of poplar caused by poplar borer.

(After Chrystal.) 


\section{The Locust Borer}

\section{(Cyllene robiniae Forst.)}

The common or black locusts, or acacias, as they are sometimes called, are frequently disfigured on the trunks by ugly scars which open into tunnels the size of a lead pencil, cut by whitish grubs about an inch in length. The adult is a long-horned beetle, three-fourths of an inch in length, black, marked with transverse yellow lines, commonly found on goldenrod blossoms during September. The females lay their eggs singly in crevices in the bark of locust trees during autumn. The young grubs pass the winter in the inner bark and the

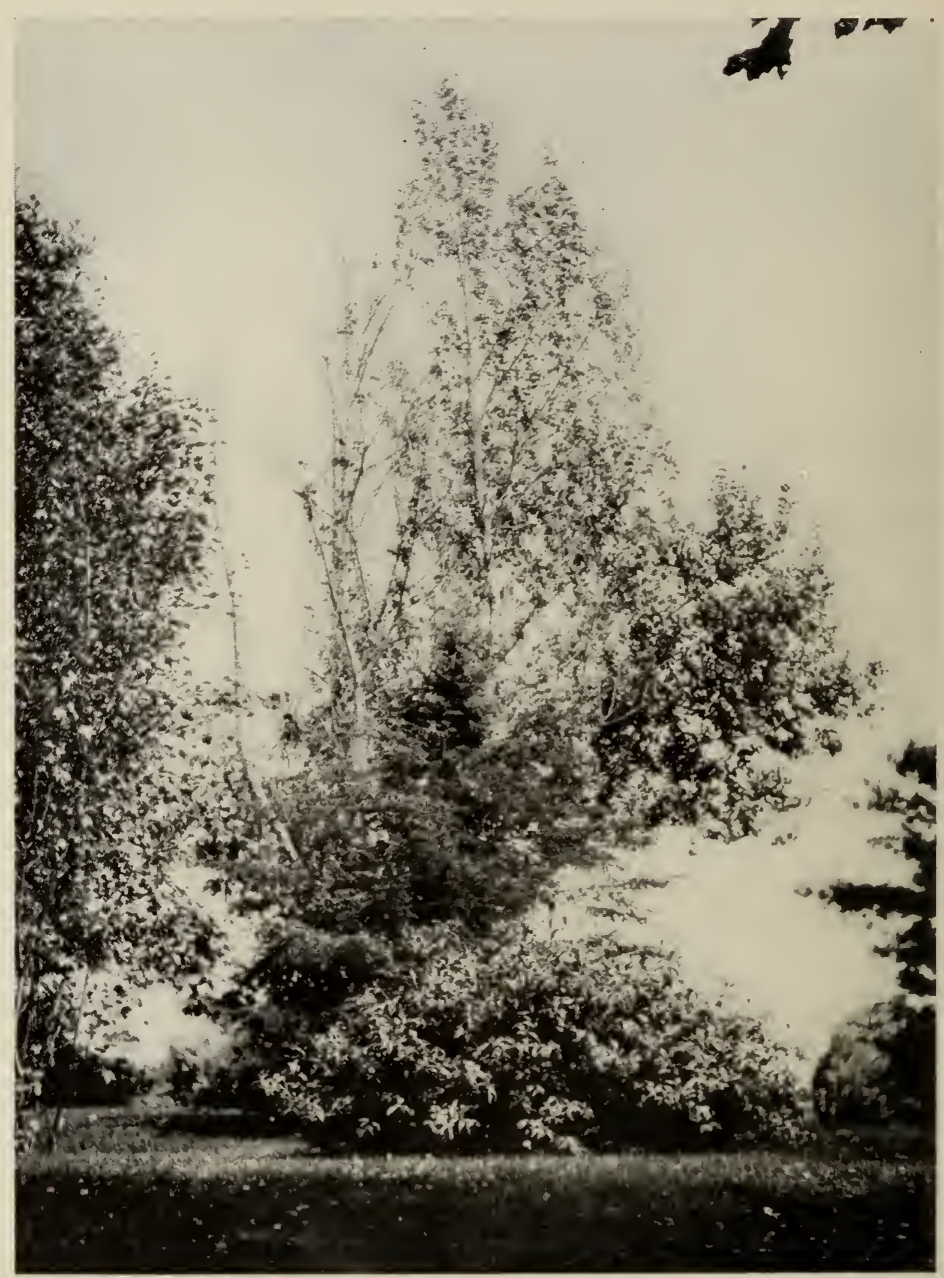

FIG. 49.-Poplar injured by poplar borer. (After (hrystai.)

following spring they develop rapidly, cutting winding tumnels deep into the wood and upward from the point of entrance, pupating about midsummer. The progress of the injury is indicated by extruded frass, and dying sappy bark.

Control.-On valuable ornamental trees the roung borers can usually be killed by spraying the infested parts of the trunk shortly after growth com- 


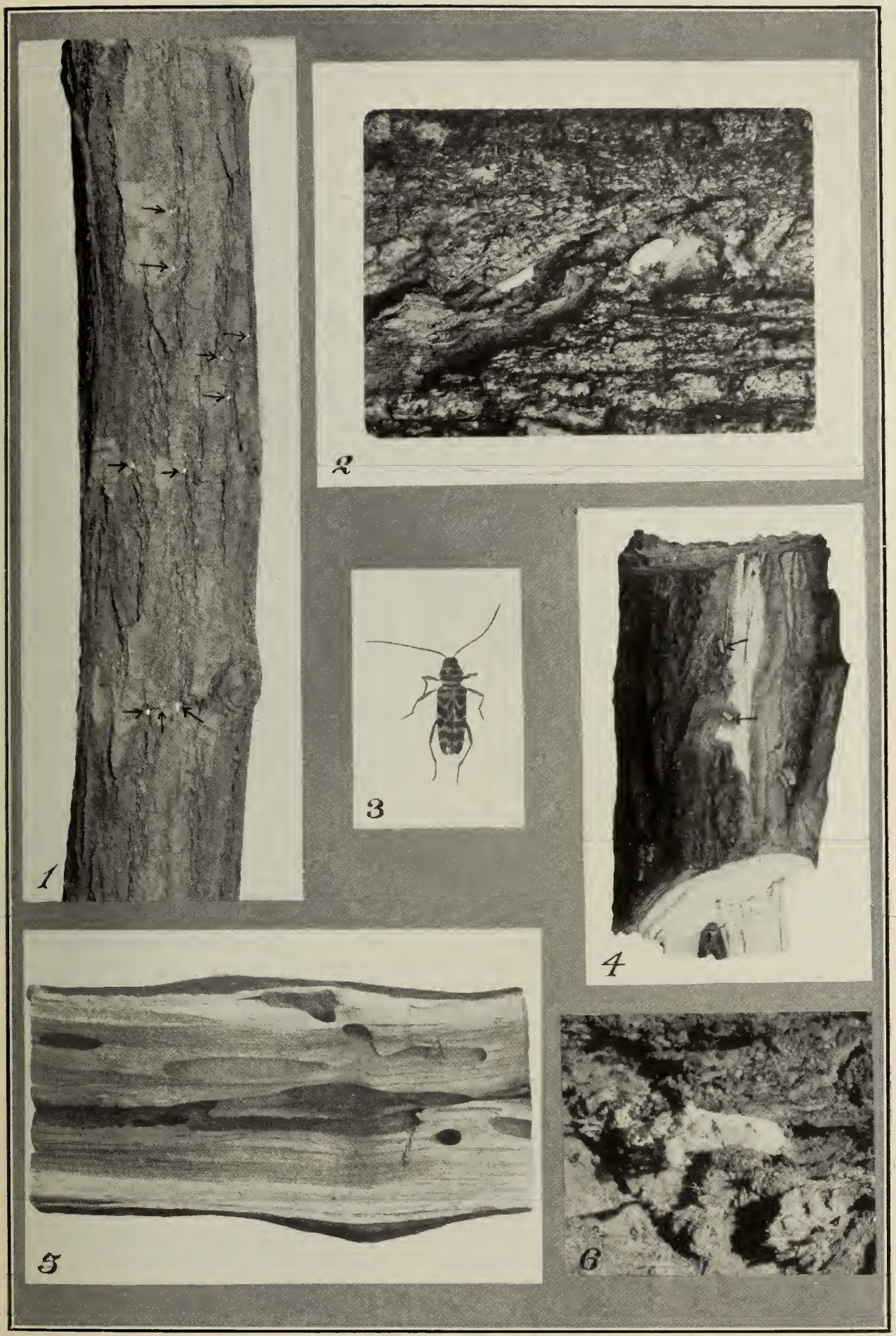

FIG. 50.-Locust borer. 1. Eggs on bark. 2. Same enlarged. 3. Adult. 4. Hibernating larvae. 5. Larval mines. 6. Egg hatched and filled with boring dust. (After Swaine.) 
mences in spring with one-quarter pound of sodium arsenate, or other solubie arsenate, in five gallons of water in which one quart of miscible oil has been mixed. The larger borers may be killed during June by means of a knife and wire or by injecting carbon bisulphide into the borings. All badly infested and useless trees and branches should be removed and burned before midsummer. Where possible all goldenrod plants in the neighbourhood should be destroyed.

It is stated that locust groves planted in thick stands or grown under shade for the first fifteen years are free from borer injury.*

\section{The Mottled Willow Borer \\ (Cryptorhynchus lapathi Linn.)}

This European species has become established in many parts of Eastern North America and it is abundant in southern Ontario and southern Quebec. It causes serious injury to poplars and willows, particularly to nursery stock, fields of basket willow and to ornamental trees.

The adult insect is a hard-shelled snout beetle, about two-fifths of an inch in length, covered with black and pale scales, with the hinder third of the wingcovers pale pink in colour. The beetles appear in July and August and feed on the young shoots, later depositing their eggs in holes which they cut into the corky part of the older bark, frequently about scars. The young are whitish, legless grubs; they feed on the soft tissue of the inner bark and outer wood, passing the winter as partly grown grubs. Feeding is continued in the spring during April and May and the dark moist frass then expelled in quantities from the tunnels indicates that the larvae are ravenously at work. Boring proceeds usually around the trunk or branch with the result the tree is often girdled. When nearly full grown the grub bores upward into the wood and pupates during midsummer, changing to the beetle which cuts its way out in July and August. The injury is evidenced by the frass and sap exuding from the tunnels and by the dying bark overlying the injured parts. The smaller trees are badly injured and frequently rendered useless or killed by the borings.

Control.-The most satisfactory method of control is to coat the infested parts with carbolineum during the first warm spring weather in late March or early April, rubbing it in thoroughly with cotton waste. Nursery trees usually require treatment only on the lower four or five feet of the trunk. The base of the tree is most seriously affected and requires special attention, but the carbolineum should not be allowed to reach the roots. $\dagger$ Very badly infested trees should be cut and burned before May.

\section{The White Pine Weevil}

\section{(Pissodes strobi Peck.)}

This insect is the most serious enemy of white pines in Eastern Canada. It injures young trees from 5 to 30 feet in height by destroying the terminal shoots, and in this way it produces a more or less serious distortion of the trunk. It is most commonly found attacking white pine, but it occurs also on both Norway spruce and red spruce.

The adult is a brown snout-beetle about one-fourth of an inch long, with two whitish spots on the back behind the middle. The females place the eggs in cavities cut in the bark, usually on the terminal shoots of young pines, in May or June. The whitish, footless grubs eat their way into the wood towards the heart. When the grubs are very numerous the terminal shoot is thoroughly

* Craighead, U.S. Dept. Agric. Bull. 787.

$\dagger$ Matheson, Cornell University, Bull. 388. 
riddled and dies towards midsummer. Chip-cocoons are formed at the enlarged ends of the tunnels in which pupation occurs. The adult beetles then eat their way out from the shoots in late summer, from about the end of July onwards to the middle of September.

Control.-On ornamental trees and small plantations the dying tips should be cut off below the infested portion in June and July and left near the infested trees in boxes or barrels securely covered with fine wire netting. This will retain the weevils but allow the useful parasites which may be present to escape.

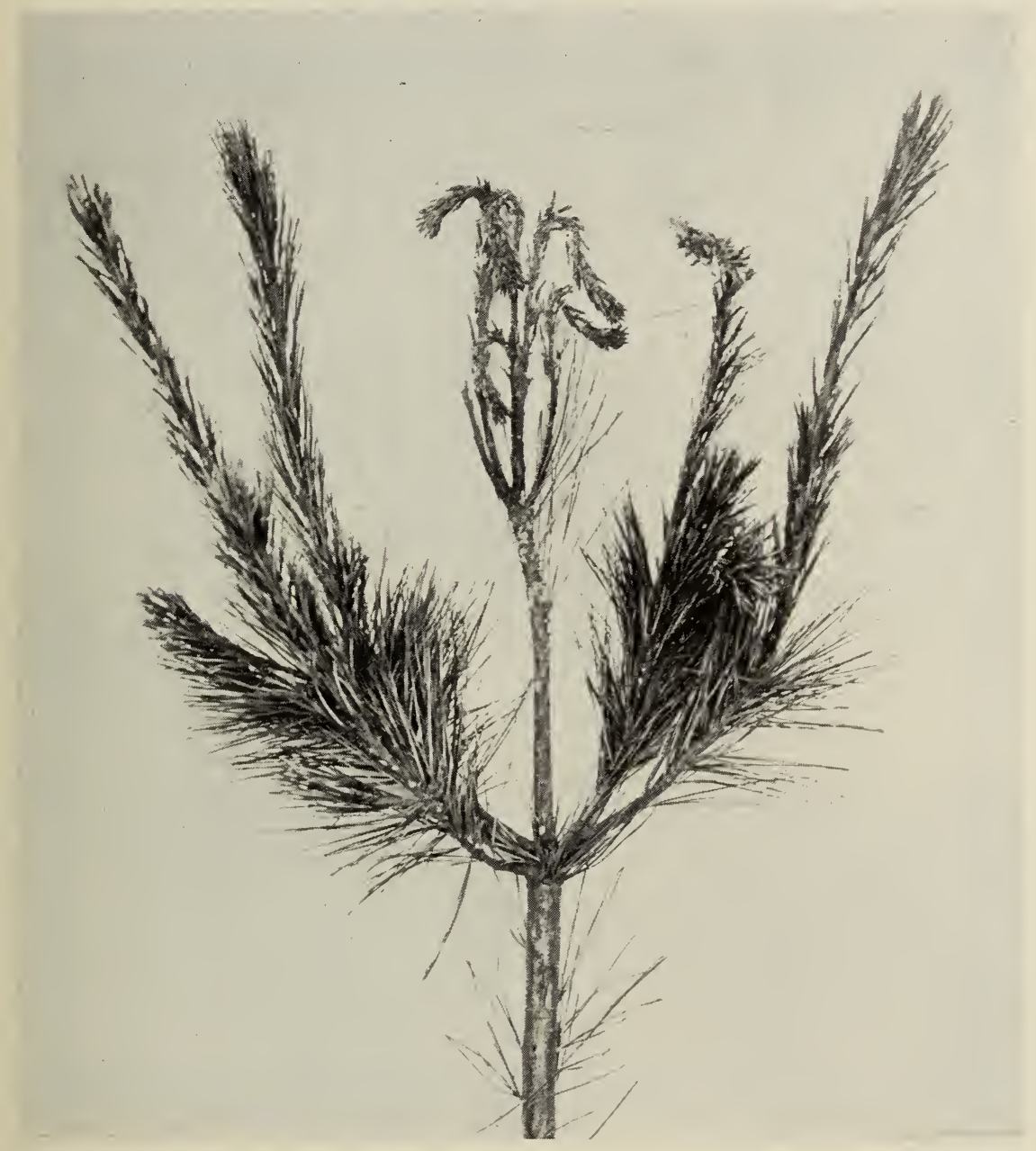

FIG. 51.-White pine shoot injured by white pine weevil. (After Swaine.)

The container should not be emptied till the following June, when the treatment should be repeated if the injury is still evident. Burning the infested shoots collected is a less desirable way of destroying the grubs.

It has been noticed that pines growing under poplar of the same age are usually immune from weevil attack. In planting belts and blocks of white pine this method should be tried, planting the pine and poplar alternately each way, spaced 4 by 4 feet, with a view to removing the poplar as the trees develop. 


\section{The Flat-headed Apple Tree Borer}

(Chrysobothris femorata Say)

This insect, though an important pest in the apple orchard, is also responsible for attacking a variety of shade trees, particularly oak and mountain ash.

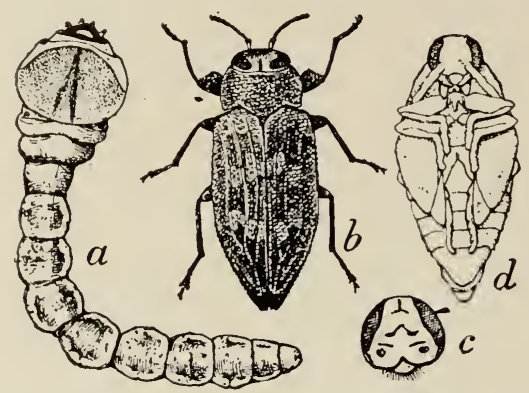

The beetle is about half an inch in length, dark grey and of metallic lustre. The eggs are laid in the summer on the bark of the host tree, and the flat-headed, legless grubs work through the sapwood into the heart wood where they hibernait.

Control.-Since the beetle appears to have a preference for trees that are unhealthy, it would be well to prune out and burn all diseased and dying wood. Carbon bisulphide can be injected into the

Fig. 52.-Flat-headed apple tree borer life- tunnels or the young larvae cut out with history stages:- $(a)$ larva; $(b)$ beetle; $(c)$ a sharp knife and the injury creosoted.
section of anal segment; $(d)$ pupa; (After a she Riley.)

The OAk Twig-Pruner

(Hypermallus villosus Fab.)

This species is frequently abundant in Eastern Canada, pruning off the twigs of oaks. It is known, also, to attack maple, hickory and locust. The eggs are laid in midsummer on the smaller branches, and the young grubs bore under the bark, and later into the centre of the twigs, thereby weakening them to such an extent that they break off readily during the first wind storm and drop to the ground.

Control.-As the fallen twigs contain the grubs they should be gathered and burned during the autumn or early spring in order to prevent the spread of the infestation.

\section{The Lilac Borer}

\section{(Podosesia syringae Harris)}

This is a common pest of lilacs. The injury is caused by a whitish caterpillar, the larva of a clear-winged moth, boring in the base of the stem. The injury often takes the form of ugly scars, punctured with exit holes. The stems are frequently girdled and killed where many larvae work together.

Control.-Valuable lilacs should be examined during the early summer and any borers in the stems removed with a sharp knife or killed by injecting carbon bisulphide into the tunnels, retaining the fumes for a few hours with a plug of putty or clay. The holes should later be coated with tar or creosote and filled with putty. Dying and unthrifty stems should be cut out and burned as soon as they are discovered.

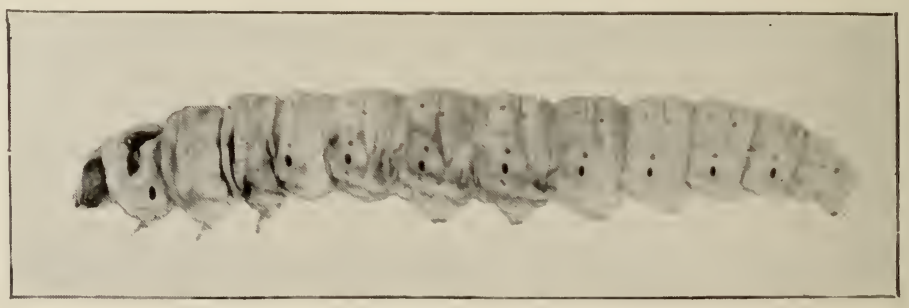

Fig. 53.-Carpenter worm. (After Hutchings.) 

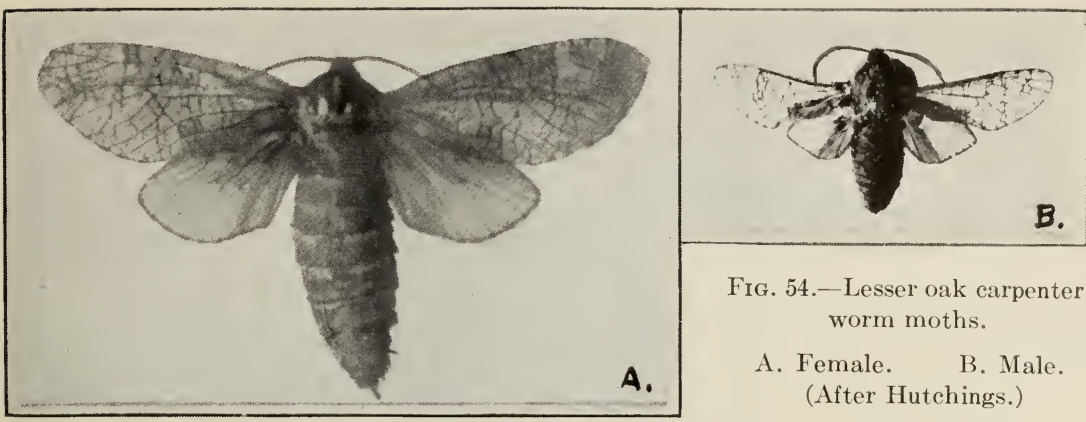

Fig. 54.--Lesser oak carpenter worm moths.

A. Female. B. Male. (After Hutchings.)

The Carpenter Worm

(Prionoxystus robiniae Peck)

This borer, a large, white, or reddish-white caterpillar with a brown head, about $21 / 2$ inches long, is found boring in the wood of the trunks and branches of hardwood trees. The adult female is a stout, spindle-shaped, grayish moth with a spread of two and a half inches across its mottled wings, while the male is somewhat smaller, very trim in outline, with the fore-wings grey and pointed and the hind-wings bright orange in colour. The dark brown, oval eggs are deposited in crevices of the bark, and the caterpillar bores through the bark and sapwood deep into the heart-wood, in which it excavates large, more or less vertical tunnels. It probably lives three years in the wood and finally changes to a large brownish pupa which projects from the tunnel openings on the surface before disclosing the moth. Its work results in unsightly deformities on the trunks of the infested trees, and destructive fungi obtaining entrance through the burrows of the caterpillar, continue the destruction. It is a serious enemy, in Eastern Canada, to ash, maple and black locust trees and has been recorded also from willow, poplar, oak, elm and chestnut.

Control.- The control of this insect is difficult and feasible only on valuable trees. The best practice is to trim away the roughest portions of the deform-

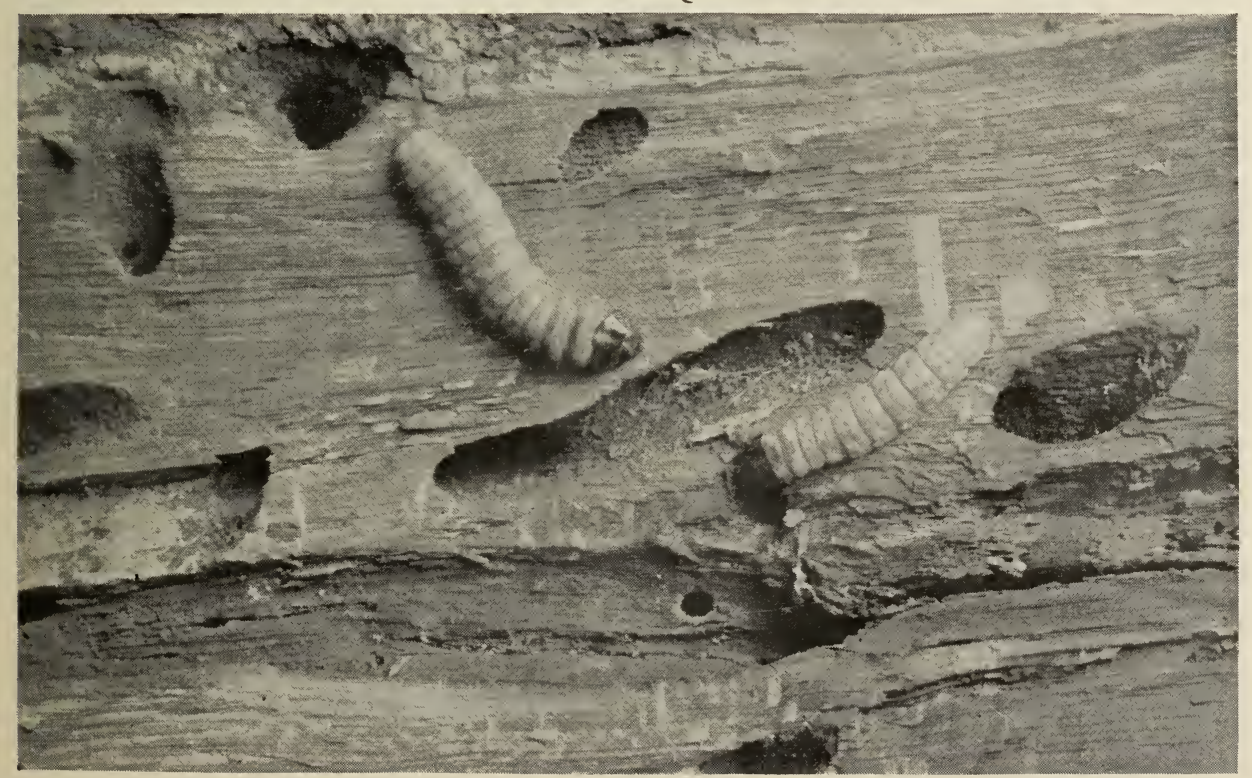

FIG. 55.-Red oak $\log$ showing severe injury by carpenter worms. (After Hutchings.) 
ities in which the caterpillars are working and then inject a sufficient amount of carbon bisulphide with a syringe into the borings and close all the holes with putty, clay or soap. Some of the larvae may be killed with a knife and wire. It has been found beneficial to spray the trunks and larger branches with poisoned kerosene emulsion during August. (See bottom page 8.)

\section{The Lesser Oak Carpenter Worm \\ (Prionoxystus macmurtrei Guer.-Men.)}

This species resembles, in many respects, the carpenter worm in appearance and in habit, except that the grey wings of the female are crossed by a number of black wavy lines, and the male moth is very small, about $\frac{5}{8}$-inch long, and is clear winged. The larva bores in living trunks of red oak (Q. rubra Linn.) seriously disfiguring and weakening or even killing trees which are badly affected. The tunnelling is carried up into the heartwood and deep auger-like holes are formed. (See figs. 54 and 55.)

Control.-This is the same as for the carpenter worm, given in the preceding paragraph.

\section{The Maple Sesian \\ (Sesia acerni Clem.)}

This species is injurious to hard and soft maples. The adult, a clearwinged, wasp-like moth with a bright red, fan-like tuft of scales at the end of the abdomen, deposits its eggs usually about wounds on the trunk, between May and June, and the caterpillars are often found boring in the developing wound tissue. Large, unsightly scars and greatly weakened trees result from their work.

Control.-Wounds resulting from any cause should be properly trimmed, disinfected and filled with grafting wax or putty as soon as discovered. Trunks infested with the larvae should be examined late in the season, the borers re-

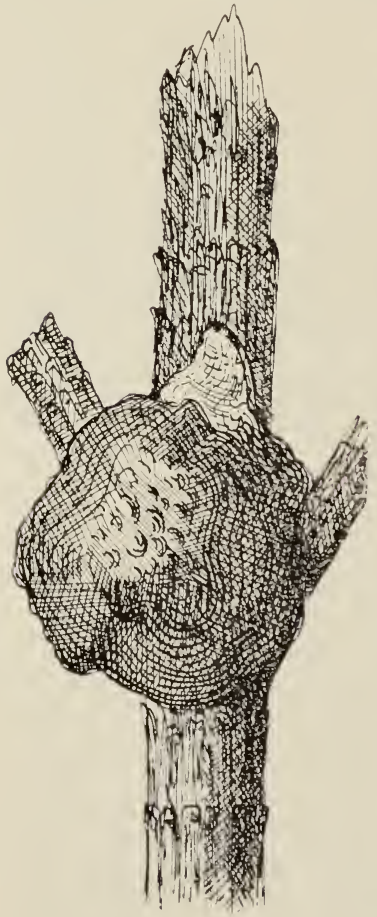

Fig. 56.--Nodule produced by pitch-mass borer. (After de Gryse.) moved and the wounds properly smoothed and covered with tar or paint.

\section{The Pitch-mass Borer \\ (Parharmonia pini Kellicott)}

This and allied species produce large masses of pitch on the trunks of pine and spruce. The larvae generally attack just below a branch, or at a wound opening and excavate winding tummels in the sapwood. Pupation occurs in the pitch-mass, and the pupal cases are made to project to the exterior sufficiently to allow the moths to escape.

Control.-When they occur on ornamental trees the pitch-masses should be removed and the caterpillars lestroyed.

\section{The Pitch Twig Moth \\ (Evetria comstochiana Fernald)}

The caterpillars of this moth produce rounded masses of pitch on the branches of hard pines, usually in the crotches of the twigs. Under the pitch-masses are short tumnels cut by yellowish or brownish caterpillars about half an inch in length. They hibernate under cover of the masses on the twigs, pupate in the spring, and the adults, small reddish-brown moths, appear in May and June.

Control.- When necessary open the pitch-masses and destroy the larvae. 


\section{The European Pine-shoot Moth \\ (Rhyacionia buoliana Schiff.)}

This injurious species has been introduced into the Eastern States from Europe, and has been found recently in different parts of Canada, as for example, in southern Ontario, Nova Scotia and British Columbia. The small, brownish caterpillars destroy many of the buds on young trees and produce a distorted growth. It affects many species of pines in Europe and may be expected to prove a serious enemy in pine nurseries and plantations wherever it becomes abundant. The moths are small, reddish-yellow with silver markings; they appear in midsummer and deposit eggs on the terminal buds. (See fig. 58.)

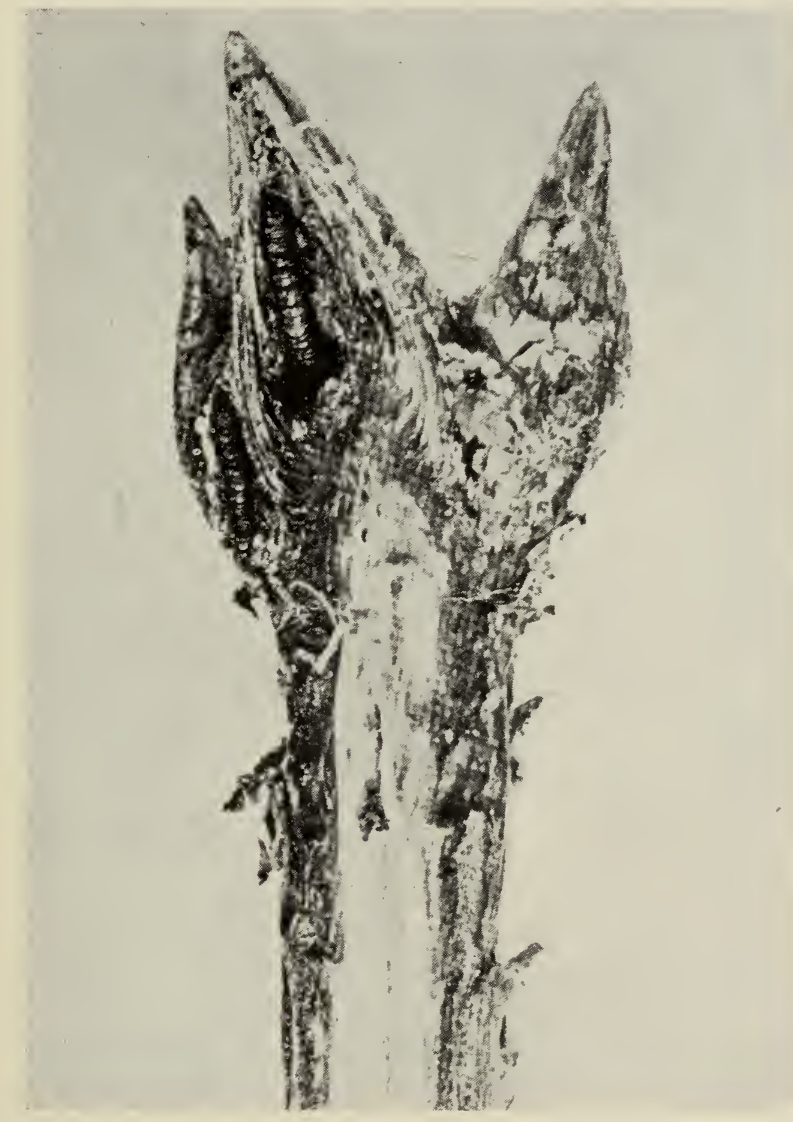

FIG. 57.-Caterpillars of the pine-shoot moth destroying pine buds. (After Busck.)

Control.- Suspected injuries by this insect should be at once submitted to an entomologist for determination and every effort should be made to eradicate an infestation. Cutting and burning infested shoots at the first sign of injury and the destruction of heavily infested trees are the only measures that can be recommended.

\section{PLANT LICE OR APHIDS}

Plant lice are minute, sucking insects, usually greenish or dark in colour, frequently wingless, occurring in a great variety of species and affecting many kinds of plants. There are usually many generations during the season, hastened by the production of living young, so that these insects may multiply with an 
astounding rapidity, unless held in check by natural control agencies which include lady bird beetles, the maggots of syrphus flies, the larvae of aphis lions, and adver'se weather conditions.

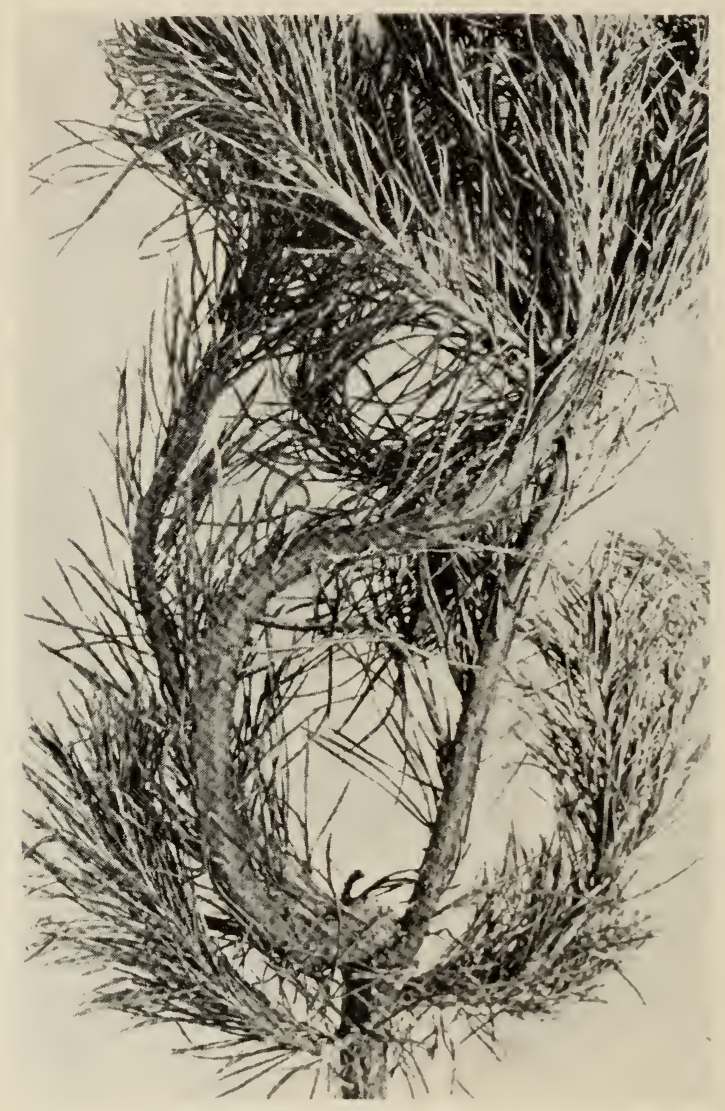

FIG. 58.-Twisted growth of young pine trees caused by work of the pine-shoot moth caterpillar. (After Busck.)
During the summer winged individuals may be produced which fly to other species of plants and give rise to another series of generations, the last of which return to the origina! host. Often towards the close of the season a sexual generation produces eggs by which the species is carried over winter.

The feeding of some species of plant lice distorts the plant tissues; a few of the gallmaking aphids are mentioned in another section.

In general, plant lice are controlled by spraying with contact insecticides such as nicotine sulphate and kerosene emulsion. (See page 8.)

\section{The Pine Bark Aphis \\ (Chermes (Adelges) pinicorticis Fitch)}

This is a common enemy of cultivated white pines. It appears as flocculent white masses upon the green bark of the trunk and branches. Like the spruce gall aphids it is rarely of any importance as a forest insect, but its effect upon the smaller isolated pines, growing under unthrifty conditions, is often serious.

The living plant lice, dark-reddish in colour, are found upon the more tender parts of the bark sucking up the sap through their slender beaks. They secrete an immense amount of fine white wax, which covers them and gives the characteristic flocculent appearance to infested trees, as though patches of wool had been gummed on the bark. Whenever this insect becomes very abundant, serious injury may be expected to the infested trees.

Control.-Pines growing under suitable conditions are less likely to be seriously affected. It is, therefore, important to give the trees the best possible conditions for growth, including sunlight and an abundance of water in dry periods. The insects may be killed by thoroughly spraying the infested portions of the bark with strong kerosene emulsion, 1 part of the stock solution in 2 parts of water, or miscible oil at the rate of one part oil in twenty parts of water, in the early season before the buds open. The spray will be more effective if the insects and the flocculent covering have been previously removed in part by a strong spray of water or by means of a stiff brush wet with very strong soap suds. Spraying with weak kerosene emulsion or miscible oil late in May after the young are found crawling on the bark is also recommended. When sufficient pressure is available, thorough spraying with water from a garden hose is beneficial in destroying many of the insects. 


\section{The Negundo Plant Louse \\ (Chaitophorus negundinis Thos.)}

Enormous numbers of green plant lice occur on the foliage of Manitoba maples, distorting the leaves and disfiguring them by a copious exudation of honey dew on which a sooty fungus grows abundantly.

Control.-Nicotine sulphate and soap or kerosene emulsion should be applied as soon as the injury is observed.

\section{Maple Plant Lice}

Several species of plant lice may become very abundant on hard and soft maples. When control measures are required, spray with a contact insecticide such as nicotine sulphate.

\section{The Ely Woolly Aphis}

(Schizoneura lanigera Hausm.)

Elm leaves are often badly curled and twisted into rosettes by plant lice of this species. About the first of July the insects leave the elm leaves and live upon the bark of neighbouring apple trees for the remainder of the season.

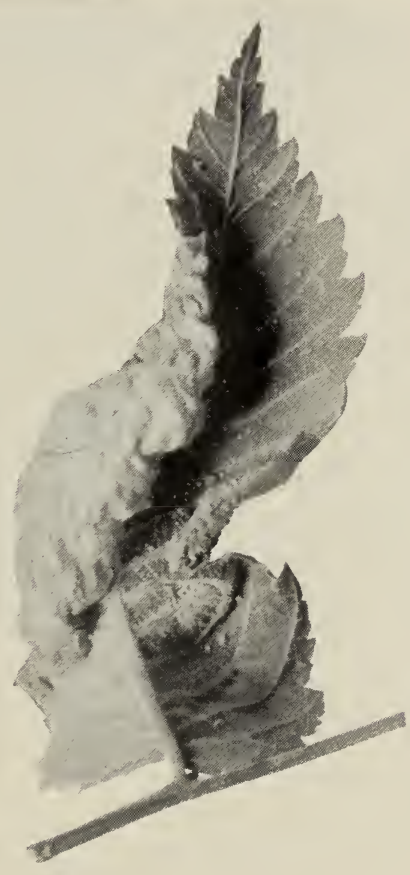

Control measures for this insect are rarely needed; although the destruction of worthless apple trees is advisable.

Fig. 59.-Elm leaf curled by woolly aphis. (After Ross.)

\section{The Larch Woolly Aphis}

(Chermes strobilobius Kalt.)

This small woolly plant louse is frequently abundant on cultivated larches. The trees sometimes appear as though covered with tiny snow-flakes, from the abundance of white wool-like wax threads covering the lice feeding upon the leaves. The injury is seldom serious, but may weaken the trees when the insects are very abundant.

Control.-Spraying with kerosene emulsion or nicotine sulphate and soap is an effective remedy.

\section{The Beech Woolly Aphis \\ (Cryptococcus fagi Barensps.)}

This destructive European species has become established in parts of Nova Scotia and Prince Edward Island, and has apparently caused considerable injury. The minute bark lice secrete a large amount of white, wool-like wax threads, so that, when they are very abundant, the bark becomes coated with a whitish, felt-like mass. 
Control.-Thorough spraying with a strong contact insecticide (such as an oil emulsion) in early spring, preceded, where feasible, by the removal of

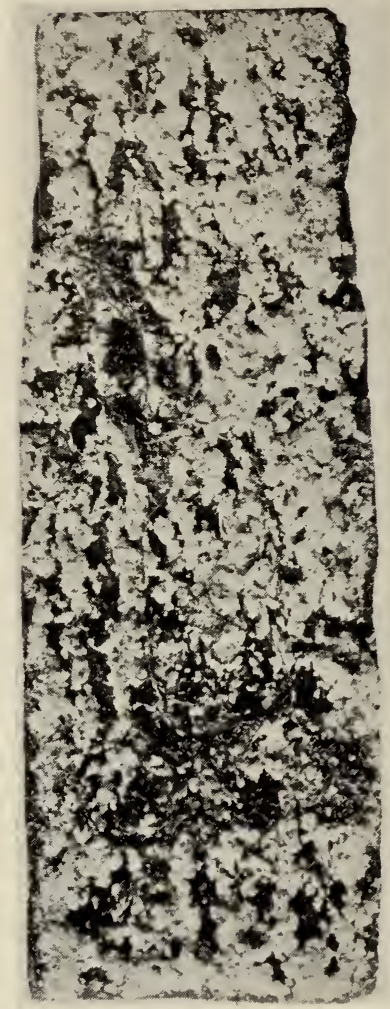

FIG. 60.-White flocculent masses of the woolly aphis on beech. (Original.) much of the wool-like coating by means of a longhandled brush, is the only remedy that can yet be suggested.

\section{The Balsam Twig Aphis}

\section{(Mindarus abietinus Koch.)}

This minute plant louse frequently infests balsam twigs in immense numbers early in the season causing the needles to become badly curled and twisted. Many twigs are killed when the insects are very numerous; the injured twigs are always unsightly, and a serious distortion of the trunk may at times occur.

Control.-Spraying with kerosene emulsion, or nicotine sulphate and soap when the trouble is first noticed, and again as required, will hold the insects in check on ornamental trees.

\section{SCALE INSECTS}

\section{The Oyster-shell Scale \\ (Lepidosaphes ulmi Linn.)}

This scale insect occurs sometimes in immense numbers on the bark of willow, poplar, ash and other shade trees and shrubs, and it is also a well known enemy of fruit trees. The scales are about oneeighth of an inch in length, and shaped like a miniature oyster shell. The eggs over-winter beneath the female scales and hatch in late May and early June into minute, yellowish-white lice, which distribute themselves over the bark for a short time and then become permanently attached thereto by their slender sucking mouth-parts.

Control.-They may be controlled by lime sulphur spray, commercial lime sulphur (1.035 sp. gr.), five gallons to 35 gallons of water, or by miscible oil, one to fifteen, applied before growth starts in the spring. Spraying with nicotine sulphate and soap shortly after the eggs have hatched is beneficial.

\section{The San José Scale}

\section{(Aspidiotus perniciosus Comst.)}

This scale insect has been very destructive in the past to orchard trees and severely affects deciduous shade trees and shrubs in southern Ontario. The female insect is minute, yellow, without legs or antennae, covered by a flat, circular, greyish scale about $\frac{1}{15}$ inch in diameter, with a central dark or yellowish nipple. The male scale is smaller than the female. The insects beneath the scales feed by sucking the sap. They multiply and spread over the bark with great

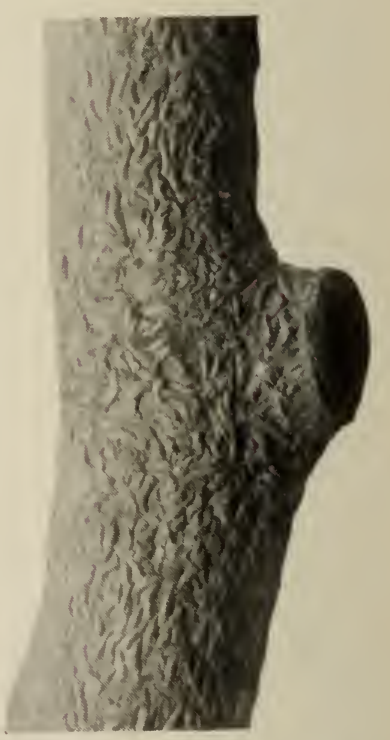

Fig. 61.-Oyster-shell scale on apple. (After Ross.) 
rapidity, the young crawling about for a short time nefore fixing themselves permanently by a slender beak thrust into the bark and secreting the covering scale.

Control.-Control may be effected by spraying thoroughly in the late fall or in early spring before growth starts with miscible oil, one to fifteen, or with the winter strength of lime-sulphur wash, at the rate of five gallons of commercial lime-sulphur (1.035 sp. gr.) to thirtyfive gallons of water.

\section{The Pine Leaf Scale \\ (Chionaspis pinifoliae Fitch)}

The needles of pines and spruces are frequently affected by this small, slender, whitish scale, and when very abundant it gives the foliage a somewhat greyish appearance and seriously affects the health of the trees. Purple eggs under the female scales hatch in June.

Control.-It is recommended to spray with a weak contact insecticide during the latter part of June while the young are crawling about on the foliage. Spraying in early spring before growth starts with miscible oil in the proportion of one to fifteen will clean the leaves of this pest.

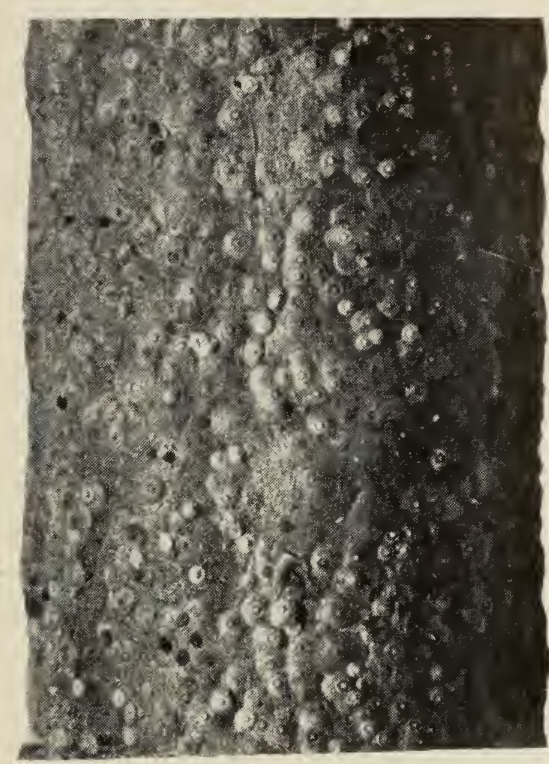

FIG. 62.-San José scale on apple; enlarged about seven times. (After Ross.)

\section{The Spruce Bud-scale}

(Physokermes piceae Schr.)

Several of these brownish, subglobular scales, about one-eighth of an inch in diameter, may often be found in the axils of the twigs on unthrifty or dying

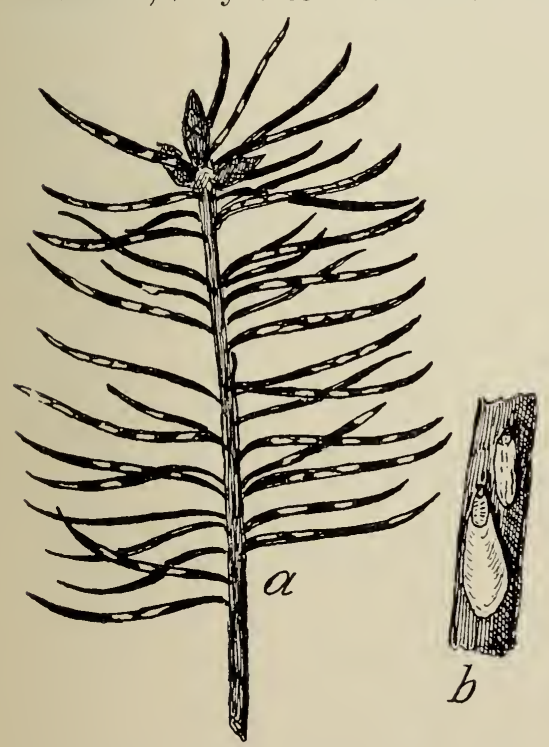

FIG. 63.-(a) Spruce twig infested by pineleaf scale, natural size; (b) male and
female scales enlarged. (After de Gryse.) branches of cultivated spruces. The injury is not uncommon in Eastern Canada, but only rarely is it abundant enough to demand treatment.

Control.- Spray the infested foliage with nicotine sulphate late in July, while the young are crawling on the bark.

\section{The Golem Oak Scale}

(Asterolecanium variolosum Ratz.)

Minute, rounded, convex, golden scales, each sunk in a small pit, are sometimes very numerous and destructive on oak twigs in parts of Eastern Canada. The insects suck the sap, and when numerous seriously weaken the trees. The young appear in May and early June.

Control.-A spray of kerosene emulsion, 1 to 9 , applied while the unprotected young are moving on the bark is a simple method of control. Badly infested trees should be sprayed in early spring, before the growth starts, with miscible oil, one to fifteen. 


\section{The Black-Banded Maple Scale \\ (Eulecanium nigrofasciatum Perg.)}

The limbs of maples and other deciduous trees are sometimes severely injured by this red and black, strongly convex scale, less than one-fifth of an inch long, resembling a minute tortoise shell, thickly studded over the bark of the smaller branches. The young appear in early summer and attach themselves to the bark by their sucking mouth-parts.

Control.-This may be obtained by an early spring application of miscible oil, one part of oil to fifteen parts of water. On sugar maples use nicotine sulphate while the young are crawling on the bark about the end of June. Tortoise-shell scales of other species found on shade trees may be controlled in the same way.

\section{The Cottony Maple Scale (Pulvinaria vitis Linn.)}

This scale insect is sometimes very abundant on maples and other deciduous shade trees in our eastern cities. It becomes conspicuous early in June, particularly on the under side of maple twigs, when the white, cottony egg-mass, containing an enormous number of eggs, protrudes from beneath the female scale. The young lice spend the summer on

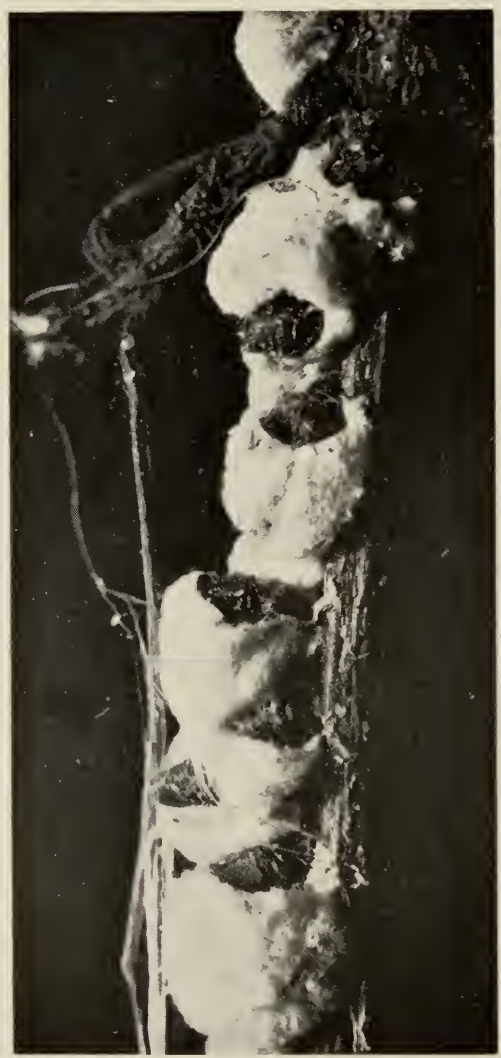

FIG. 64.-Cottony maple scale; enlarged. (Original.) the undersides of the leaves sucking the juice through a slender beak. In the autumn the females migrate back to the twigs where they hibernate.

Control.- Spray with miscible oil, one to fifteen parts of water, in spring before growth starts. Weak contact sprays applied thoroughly once or twice while the young are on the leaves during July are beneficial.

\section{Thi: Maple Phenacoccus \\ (Phenacoccus acericola King)}

Females of this species and their eggs covered with an irregular cottony mass, nearly one-fourth of an inch in diameter, occur on the undersides of sugar maple leaves during the summer.

Control.-That given above for the eottony maple scale may be employed when needed.

\section{The Elm Bark-Louse}

\section{(Gossyparia spuria Modeer)}

The females of this species are dark red, scale-like, bordered with white floceulent wax, very like a fringe, about one-fourth of an inch in length, usually arranged along cracks or fissures in the bark of trunks and limbs, and irregularly on the twigs. They suck the sap from the bark, of ten killing the 
infested branches and even, finally, the trees. The leaves below infested limbs become coated with honey-dew and blackened by a fungous growth. The young appear in late June and early July and feed for a time on the leaves, migrating late in the season to the bark where they pass the winter.

Control.-The infested trunks and branches should be sprayed thoroughly in early spring before the buds open with miscible oil, one gallon in fifteen gallons of water, or kerosene emulsion, one part stock solution in three parts of water, or one gallon of concentrated lime sulphur in eight gallons of water.

\title{
The Scurfy Scale
}

(Chionaspis furfura Fitch)

This whitish, scurfy scale frequently coats the bark of cultivated shrubs. The females are about one-tenth of an inch long, oval-pointed, with a small, yellow tip. The males are much smaller and elongate.

Control.-This may be effected by spraying with miscible oil, one to fifteen, or with lime sulphur wash, in the early spring, before the buds open.

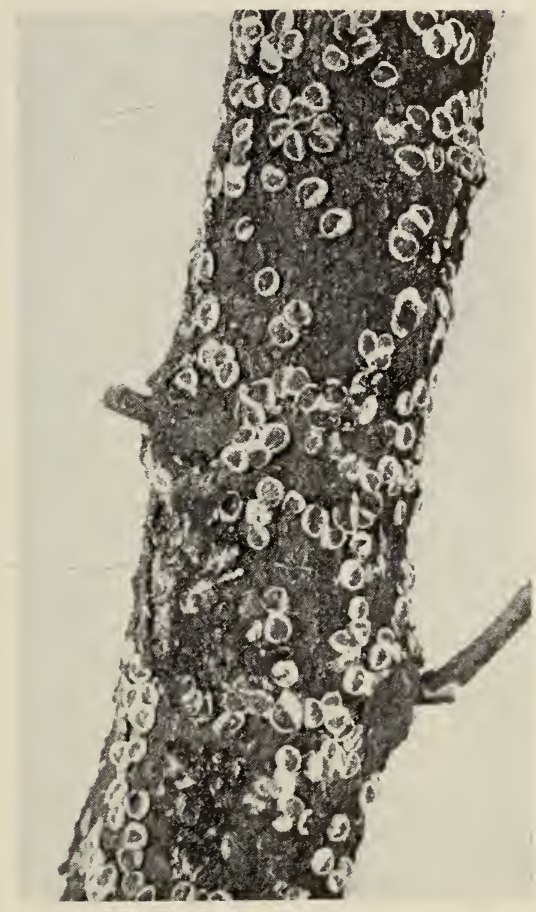

FIG. 65.-Elm bark louse; natural size. (Original.)

The Dogwood Scale (Chionaspis corni Cooley) occurs on ornamental dogwoods.

\section{GALL-MAKING INSEGTS}

\author{
The Spruce Gall Aphids
}

(Chermes (Adelges) abietis Linn.)

(Chermes (Adelges) simitis Gill.)

The gall-making aphids are probably the most destructive enemies of cultivated spruces in Eastern Canada. The injury is distinguished by conical galls formed on the ends of the twigs during early summer. The injured twigs usually die and when the galls become very numerous the health of the tree is seriously affected. Ornamental trees and spruce hedges often suffer severely.

The young plant lice hibernate on the twigs below the buds. In the spring they mature rapidly, secreting a wool-like covering, and lay many eggs. The young lice therefrom enter the axils of the young needles on the growing shoots, where they feed by sucking the plant juices. The gall then develops enclosing 
the young lice in cavities at the bases of the needles. These cavities open late in the season, as the gall tissue dries, permitting the matured insects to escape.

Control.-When only a few

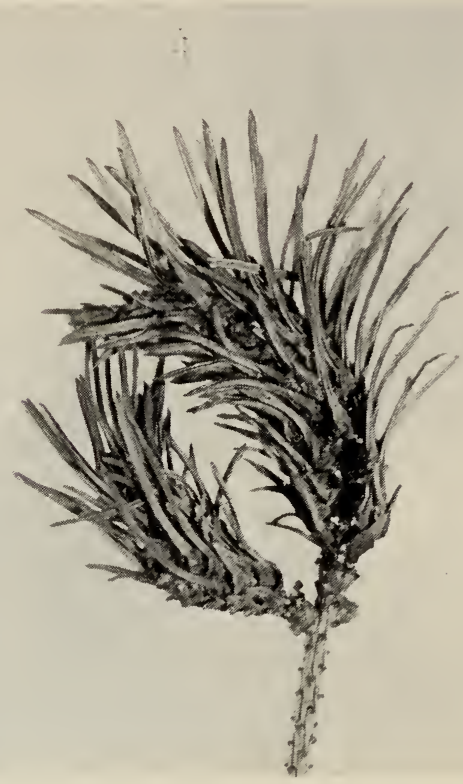

FIG. 66.--Spruce gall aphid injury. (Original.) trees are to be dealt with the galls can be removed by hand and destroyed before midsummer. Any nearby spruce trees may serve as a continued source of infestation unless they also are treated. On large trees a measure of control may be obtained by spraying the twigs thoroughly with a strong contact spray before the buds open in the spring, to kill the hibernating females. Kerosene emulsion, one part stock solution in two parts of water may be used as a dormant spray. Miscible oil as a dormant spray may also prove effective, applied at the rate of ore to twenty.

\section{The Gouty Oak Gall}

\section{(Andricus punctatus Bass.)}

Red oak twigs and small limbs are frequently affected by hard, irregularly rounded swellings from one to two inches in diameter, more or less completely surrounding the twig and often coalesced to form an elongated mass. When very abundant remove and destroy the young galls before the adult gall-wasps emerge.

Very many species of galls of various shapes occur on oaks, but rarely cause any serious injury. The bullet galls $1 / 2$ inch in diameter, and the oak apples, $1 \frac{1}{2}$ inches in diameter, are frequently seen.

The Poplar Vagabond Gall

(Mordvilkoja vagabunda Walsh)

Poplar leaves developed into a flattened convoluted sack about two inches in diameter are affected by the feeding of numerous plant lice which are found within. The galls dry and turn brown or black at the close of the season. The injury is rarely very important. Removal of the young galls from small isolated trees should be beneficial.

The Maple Bladder Gall

\section{(Phyllocoptes quadripes Shimer)}

The upper surface of maple leaves is sometimes covered with numerous, minute, green, or purple, bladder-like growths. The injury, caused by minute

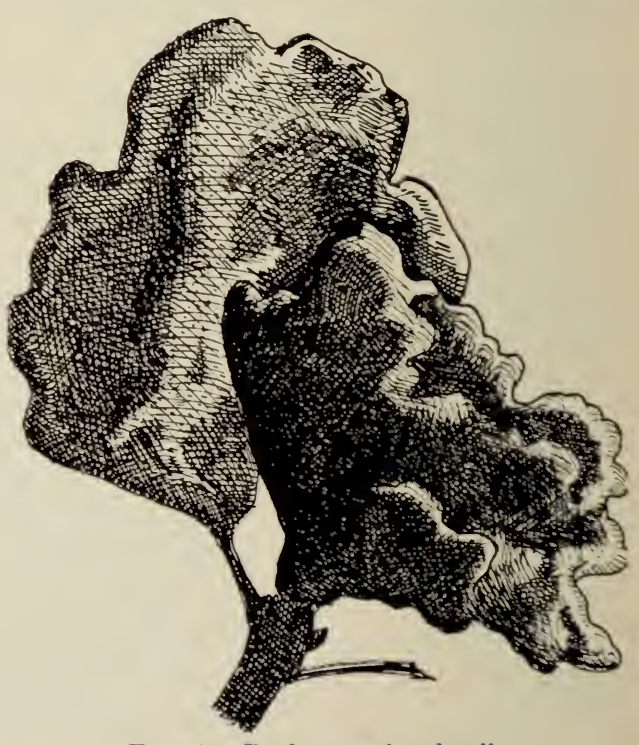

FIG. 67.-Poplar vagabond gall.

(After de Gryse.) 
plant mites, is common, but rarely severe enough to require control measures. The mites apparently hibernate on the twigs and spraying with miscible oil or lime sulphur, winter strength, in the early spring for this and similar galls is recommended when control is needed.

\section{The Box Elder Gall Fly \\ (Cecidomyia negundinis Gill.)}

Unsightly, elongate, fleshy galls, which more or less seriously interfere with the proper functioning of the leaves, are sometimes extremely abundant on Manitoba maples. This injury is caused by a minute, two-winged fly which lays its eggs in the leaves. When the galls are opened, small maggots, the larvae of the gall-fly, are found within.

Control.- The remedy suggested consists in picking off and destroying the infested leaves, so far as this is possible, as soon as the galls are noticed.

\section{The Ash Flower-gall \\ (Eriophyes fraxiniflora Felt)}

The work of this gall-mite produces a distortion of the staminate flowers of the white ash into irregularly branched and fringed masses which dry and remain on the trees over winter. The injury disfigures the trees, when abundant, and is not uncommon in Eastern Canada.

Control.-It has been recommended to spray badly infested trees with miscible oil, one to fifteen, in early spring before the buds swell.

\section{The Cockscomb Elm GaLL}

(Colopha ulmicola Fitch)

An erect wart-like growth about one inch long and one-quarter inch high, which is common on the upper surfaces of elm leaves, is the cockscomb elm gall, so called on account of its peculiar shape. It is somewhat compressed at the base, ridged on the sides and irregularlarly toothed on the top. At first the gall is green in colour when it begins to

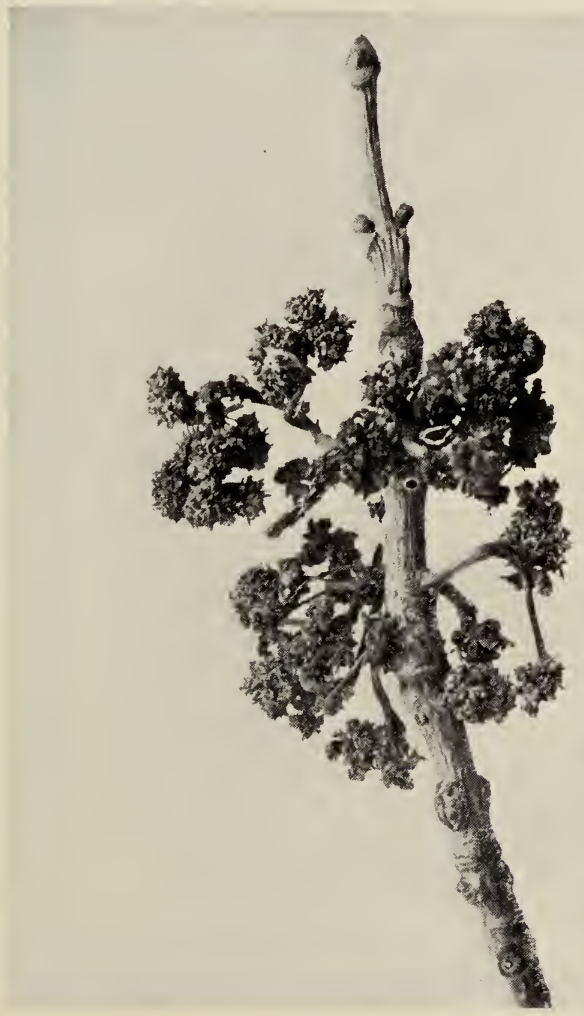

FIG. 68.-Ash flower gall; natural size. (Original.)

form in May, but later turns to brown and finally to black. In due time the plant lice which breed within the gall escape to the exterior through an orifice on the lower side of the leaf.

Control.-This species rarely causes serious injury. On small trees it would be feasible to remove and destroy the disfigured leaves. 


\section{PRINCIPAL SHADE TREES OF EASTERN CANADA AND THEIR MORE IMPORTANT INSECT ENEMIES}

Alder

Alder Leaf-miner

Arborvitae

Arborvitae Leaf-miner

Ash

Ash Flower-gall

Cankerworms

Carpenter Worm

Fall Web-worm

Forest Tent Caterpillar

Giant Silk Worms

Hickory Tussock Moth

Oyster-shell Scale

\section{Balsam Fir}

Balsam Twig Aphis

Fir Sawfly

Spruce Budworm

\section{Basswood}

Cankerworms

Giant Silk Worms

Linden Borer

Spiny Elm Caterpillar

Walkingstick Insect

White-marked Tussock Moth

\section{Beech}

Beech Woolly Aphis

\section{Birch}

Cankerworms

Birch Leaf Skeletonizer

Bronze Birch Borer

Forest Tent Caterpillar

Giant Silk Worms

Hickory Tussock Moth

Spiny Elm Caterpillar

\section{Butternut}

Black Walnut Caterpillar

Yellow Necked Caterpillar

Cedar-See Arborvitae

Cottonwood-See Poplar
Elm

Brown-tail Moth

Cankerworms

Carpenter Worm

Cockscomb Elm Gall

Elm Bark Louse

Elm Borer

Elm Leaf-beetle

Elm Leaf-miner

Elm Sawfly

Elm Woolly Aphis

Giant Silk Worms

Gypsy Moth

Hickory Tussock Moth

June Beetles

Spiny Elm Caterpillar

White-marked Tussock Moth

\section{Hawthorn}

American Tent Caterpillar

Hemlock

Spruce Budworm

Hickiory

Black Walnut Caterpillar

Yellow Necked Caterpillar

Larch

Larch Case-bearer

Larch Sawfly

Larch Woolly Aphis

Lilac

Lilac Borer

Lilac Leaf-miner

Linden-See Basswood

Locust

Carpenter Worm

Locust Borer

Maple

Antlered Maple Caterpillar

Black-banded Maple Scale

Box Elder Gall Fly

Brown-tail Moth

Carpenter Worm 
Maple-Continued

Cottony Maple Scale

Elm Sawfly

Forest Tent Caterpillar

Giant Silk Worm

Green Maple Caterpillar

Green Striped Maple Worm

Gypsy Moth

June Beetles

Maple Bladder Gall

Maple Leaf-cutter

Maple Phenacoccus

Maple Sesian

Negundo Plant Louse

Sugar Maple Borer

Walkingstick Insect

White-marked Tussock Moth

Yellow Necked Caterpillar

Oak

Brown-tail Moth

Cankerworms

Carpenter Worm

Flat-headed Apple Tree Borer

Gypsy Moth

Golden Oak Scale

Gouty Oak Gall

June Beetles

Lesser Carpenter Worm

Oak Twig Pruner

Red-humped Oak Caterpillar

Spotted Tussock Moth

Walkingstick Insect

Yellow-striped Oak Caterpillar

Pine

Abbott's Pine Sawfly

European Pine Shoot-moth

Pine Bark Aphis

Pine Leaf Scale

Pine Sawfly

Pitch-mass Borer

Pitch Twig Moth

White Pine Weevil

\section{Poplar}

Cankerworms

Carpenter Worm
Poplar-Continued

Cottonwood Leaf-beetle

Elm Sawfly

European Poplar Sawfly

Fall Webworm

Forest Tent Caterpillar

Giant Silk Worms

June Beetle

Oyster-shell Scale

Poplar Borer

Poplar Vagabond Gall

Satin Moth

Spiny Elm Caterpillar

Spotted Tussock Moth

Spotted Willow Leaf-beetle

White-marked Tussock Moth

\section{Spruce}

Fir Sawfly

Pitch-mass Borer

Spruce Bud-scale

Spruce Budworm

Spruce Gall Aphis

Walnut

Black Walnut Caterpillar

Yellow Necked Caterpillar

Willow

Brown-tail Moth

Cankerworms

Cottonwood Leaf-beetle

Elm Sawfly

Fall Webworm

Forest Tent Caterpillar

Giant Silk Worms

Gypsy Moth

June Beetles

Mottled Willow Borer

Oyster-shell Scale

Satin Moth

Spring EIm Caterpillar

Spotted Tussock Moth

White-marked Tussock Moth

Yellow Spotted Willow Slug 



\section{N D E X}

PAGE

Abbott's Pine Sawfly...... . . . . . . . 27

Alder Leaf-miner. . . . . . . . . . . . . . . . 28

American Tent Caterpillar............ 11

Antlered Maple Caterpillar........... 25

Aphids...................... . 45

Arborvitae Leaf-miner... . . . . . . . . . . 32

Arsenate of Lead................ 7

Artificial Control. ................ 5

Ash Flower-Gall.................. 53

Balsam Twig Aphis. . . . . . . . . . . . . 48

Banding the Trunks................ 9

Barrel Pumps.................... 6

Beech Woolly Aphis......... . . . . . . . 47

Birch Leaf Skeletonizer. . . . . . . . . . . . . . 19

Black-banded Maple Scale.... . . . . . . . 50

Black Walnut Caterpillar.... . . . . . . . 24

Box Elder Gall Fly. . . . . . . . . . . . . . . 53

Bronze Birch Borer. . . . . . . . . . . . . 35

Brown-tail Moth................ 16

Bucket Pumps............... 6

Cankerworms.................. 12, 13

Carpenter Worm... . . . . . . . . . . . 43

Cecropia Moth.................. 34

Clean Culture................... 4

Cockscomb Elm Gall............... 53

Cottony Maple Scale.... . . . . . . . . . 50

Contact Insecticides. . . . . . . . . . . . . 8

Cottonwood Leaf-beetle. . . . . . . . . . . . . . 32

Dogwocd Scale................. 51

Double Action Hand Pump.......... 6

Dusting. . . . . . . . . . . . . . . . . 8

Elm Bark-louse........ . . . . . . . . . . 50

Elm Borer..................... . 37

Elm Leaf-beetle. . . . . . . . . . . . . . . . 31

Elm Leaf-miner... . . . . . . . . . . . . . . . 28

EIm Sawfly... . . . . . . . . . . . . . . . 27

Elm Woolly Aphis.... . . . . . . . . . . . . 47

European Pine-shoot Moth. . . . . . . . . . . 45

European Poplar Sawfly... . . . . . . . . . . . 28

Fall Cankerworm................... 13

Fall Webworm. . . . . . . . . . . . . . . . 22

Fir Sawfly... . . . . . . . . . . . . . . . . . 28

Flat-headed Apple Tree Borer. . . . . . . . . 42

Forest Tent Caterpillar............... 10

Gall-making Insects.............. 51

Giant Silk Worms. . . . . . . . . . . . . . . . 34

Gypsy Moth.................... 14
PAGE

Golden Oak Scale.................. 49

Gouty Oak Gall... . . . . . . . . . . . . . . 52

Green Maple Caterpillar............. 26

Green-striped Maple Worm . . . . . . . . . 25

Hand Picking. . . . . . . . . . . . . . . 9

Hickory Tussock Moth.... . . . . . . . . 23

Insecticides ................. 7

Insect Stages. . . . . . . . . . . . . . 4

Io Moth..................... 34

June Beetles. . . . . . . . . . . . . . . . . 33

Kerosene Emulsion............... 8

Larch Case-bearer. . . . . . . . . . . . . . 26

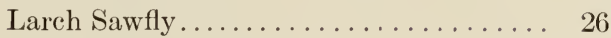

Larch Woolly Aphis.... . . . . . . . . . . . 47

Leaf Eating Insects... . . . . . . . . . . . . 10

LeConte's Pine Sawfly. . . . . . . . . . . . . . 27

Lesser Carpenter Worm. . . . . . . . . . . . . 44

Lilac Leaf-miner. . . . . . . . . . . . . . . . . 30

Lilac Borer. . . . . . . . . . . . . . . . . . . . . . . 42

Linden Borer.................. 37

Locust Borer. . . . . . . . . . . . . . . . . . 38

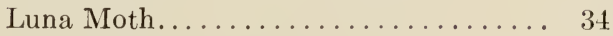

Maple Bladder Gall................. 52

Maple Leaf-Cutter. . . . . . . . . . . . . . . . . 11

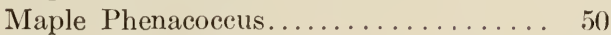

Maple Plant Lice. . . . . . . . . . . . . . . . 47

Maple Sesian................... 44

Miscible Oils................... 8

Mottled Willow Borer............. 40

Natural Control................... 5

Negundo Plant Louse. . . . . . . . . . . . . . . 47

Nicotine Sulphate............... 8

Oak Twig-pruner................. 42

Oyster-shell Scale................. 48

Pine Bark Aphis.................. 46

Pine Leaf Scale. . . . . . . . . . . . . . . . . . . . 49

Pitch-mass Borer. . . . . . . . . . . . . . . . 44

Pitch Twig Moth................. 44

Plant Lice. . . . . . . . . . . . . . . . . . . 45

Polyphemus Moth................. 34

Poisoned Contact Sprays............ 8

Poplar Borer.................... 35

Poplar Vagabond Gall.............. 52

Power Sprayer. . . . . . . . . . . . . . 67

Pumps, Spray................. 6 


\section{INDEX-Concluded}

PAGe PAGe

Red-humped Oak Caterpillar.

Spruce Gall Aphids.............. 51

Stomach Poisons.................... 7

San José Scale................... 48

Satin Moth...................... 19

Scale Insects.................. 48

Scurfy Scale................. 51

Selection and Planting.............. 3

Soap Solutions................ 8

Spotted Tussock Moth.............. 23

Spotted Willow Leaf-beetle........... 32

Spiny Elm Caterpillar............... 18

Spring Canker Worm............... 13

Spruce Bud-scale. . . . . . . . . . . . . . . . . . 49

Spruce Budworm................... 25

Sugar Maple Borer.................. 34

Treatment of Wounds.............. 3

Tree Tanglefoot................ 9

Walkingstick Insect................ 33

White-marked Tussock Moth. ........ 19

White Pine Weevil................. 40

Wood Borers................. 9, 34

Yellow-necked Caterpillar............. 2t

Yellow Spotted Willow Slug........... 31

Yellow-striped Oak Caterpillar......... 25 




\section{PUBLICATIONS ON INSECTS}

The following publications of the Department of Agriculture relating to insects are available on application to the Director of Publicity, Department of Agriculture, Ottawa:-

Pea Weevil, The.

Lime, Arsenate of .................. No.10

Corn Borer, The Control of the European............. No 16

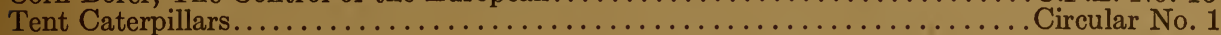

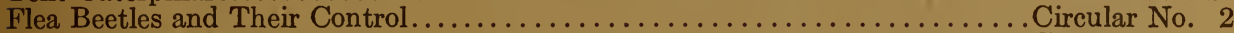

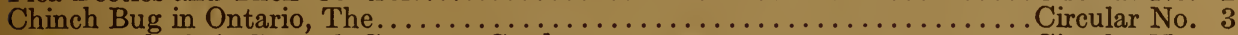

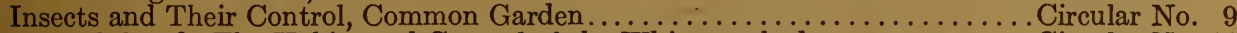

Tussock Moth, The Habits and Control of the White-marked................ Circular No. 11

Boring Caterpillars which are Liable to be Mistaken for the European Corn

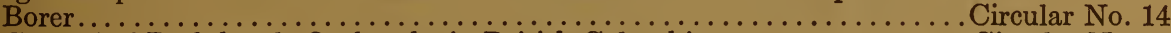

The Control of Bark-beetle Outbreaks in British Columbia.................. Circular No. 15

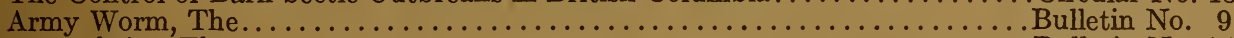

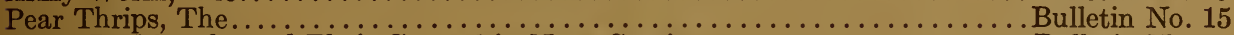

Apple Bud-Moths and Their Control in Nova Scotia....................... 16

Fruit Worms of the Apple in Nova Scotia, The........................... Nulletin No. 17

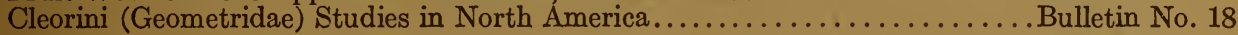

\section{NEW SERIES}

Crop Rotation to Offset the Injury of Field Crop Insects............. Circular No. 2

The Date on Which it is Safe to Reseed Fields after they have been Devastated

by the Pale Western Cutworm ................................ Circular No 4

The Fruit Tree Leaf-roller and its Control in British Columbia............... Circular No. 10

How to Foretell Outbreaks of the Pale Western Cutworm in the Prairie Provinces Circular No. 12

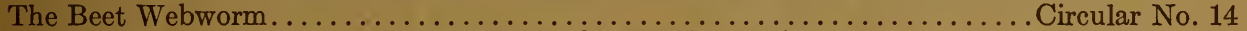

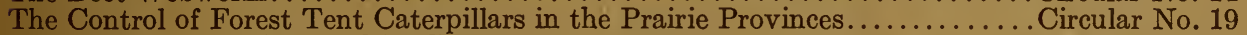

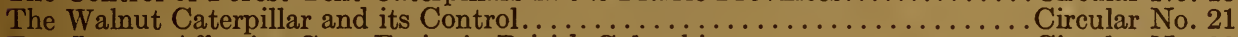

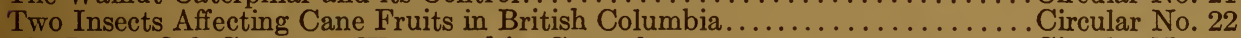

The Lesser Oak Carpenter Worm and its Control........................... Circular No. 23

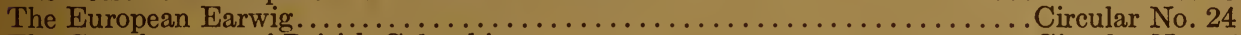

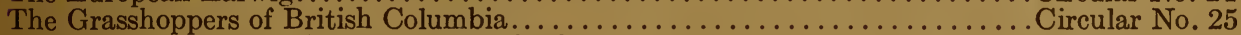

The Plum Curculio and its Control in Quebec............................ Circular No. 27

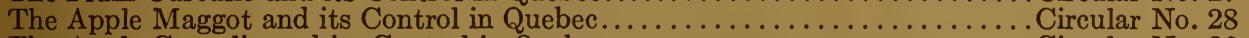

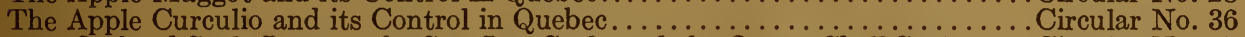

Two Orchard Scale Insects, the San José Scale and the Oyster Shell Scale........................ No. 37

The European Red Mite, a Pest of Fruit Trees...................... Circular No. 39

The Strawberry Root Weevil, with Notes on Other Insects Affecting Straw-

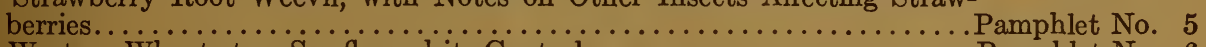

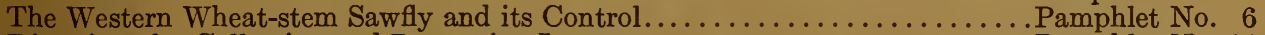

Directions for Collecting and Preserving Insects..................

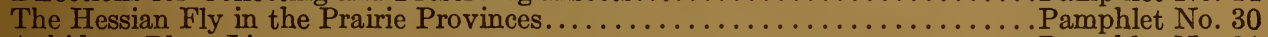

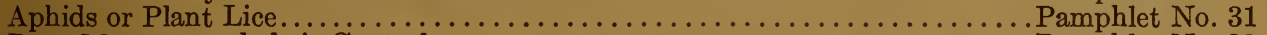

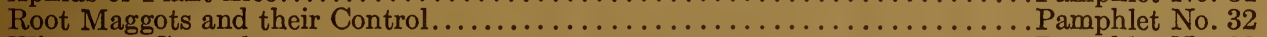

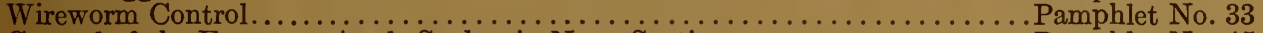

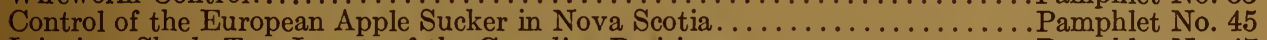

Injurious Shade Tree Insects of the Canadian Prairies.................... Pamphlet No. 47

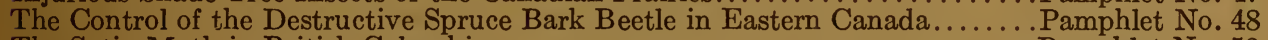

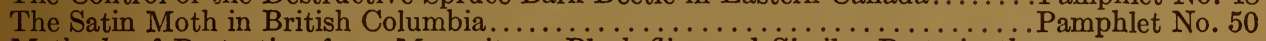

Methods of Protection from Mosquitoes, Black-flies and Similar Pests in the

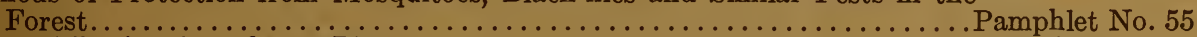

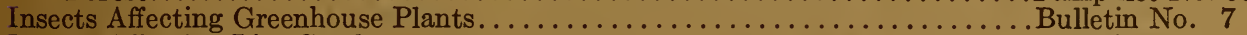

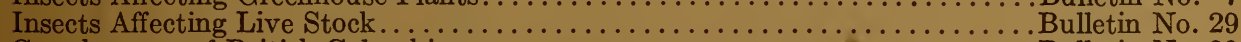

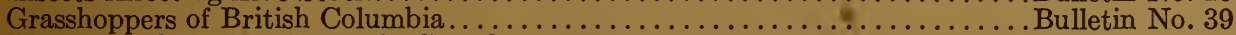

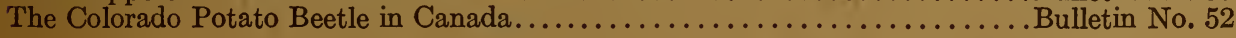


